Florida International University FIU Digital Commons

2-29-2016

\title{
Faculty Perceptions of Self-Plagiarism and Other Forms of Academic Dishonesty Among University Students
}

Carleen Vincent-Robinson

Florida International University, vincentc@fiu.edu

DOI: $10.25148 /$ etd.FIDC000226

Follow this and additional works at: https://digitalcommons.fiu.edu/etd

Part of the Higher Education Commons, and the Online and Distance Education Commons

\section{Recommended Citation}

Vincent-Robinson, Carleen, "Faculty Perceptions of Self-Plagiarism and Other Forms of Academic Dishonesty Among University Students" (2016). FIU Electronic Theses and Dissertations. 2501.

https://digitalcommons.fiu.edu/etd/2501 


\section{FLORIDA INTERNATIONAL UNIVERSITY}

Miami, Florida

\section{FACULTY PERCEPTIONS OF SELF-PLAGIARISM AND OTHER FORMS OF} ACADEMIC DISHONESTY AMONG UNIVERSITY STUDENTS

A dissertation submitted in partial fulfillment of

the requirements for the degree of

DOCTOR OF EDUCATION

in

\section{HIGHER EDUCATION}

by

Carleen Vincent-Robinson 
To: Dean Michael R. Heithaus

College of Arts, Sciences and Education

This dissertation, written by Carleen Vincent-Robinson, and entitled Faculty Perceptions of Self-Plagiarism and Other Forms of Academic Dishonesty Among University Students, having been approved in respect to style and intellectual content, is referred to you for judgment.

We have read this dissertation and recommend that it be approved.

Mido Chang

Eric Dwyer

Norma Goonen

Benjamin Baez, Major Professor

Date of Defense: February 29, 2016

The dissertation of Carleen Vincent-Robinson is approved.

Dean Michael R. Heithaus

College of Arts, Sciences and Education

Andrés G. Gil

Vice President for Research and Economic Development

And Dean of the University Graduate School

Florida International University, 2016 
(C) Copyright 2016 by Carleen Vincent-Robinson

All rights reserved. 


\section{DEDICATION}

For my daughters.... You are my reason for existing. I love you with all of my heart. 


\section{ACKNOWLEDGMENTS}

To the members of my committee, Dr. Benjamin Baez, Dr. Mido Chang, Dr. Eric Dwyer, and Dr. Norma Goonen. Thank you for your dedication to the academic process and for your continued guidance, tutelage, and patience.

To Dr. Joy Blanchard. I thank you for believing in the importance of my topic when it was deemed unimportant by others. As I continue my role within the academy, I hope that my students will see within me what I see in you-an utmost dedication to fostering an academic environment where academic integrity is demanded and expected of all.

To my friends and family. I thank you for believing in me and my ability to pursue and obtain the doctorate degree. A special thanks to Meghan Clovis for teaching me how to run specific analyses and helping me understand the place of speculation and conjecture in my writing.

To my husband, Eric. Words cannot describe the depth of my love, gratitude, or appreciation for your support as I have completed this journey. Although we experienced significant losses and triumphs as I matriculated through the program, your support never wavered. You stood firmly behind me, always ready to catch me when I stumbled. You encouraged me to continue my academic pursuits and wiped away tears of frustration as I struggled with carrying a heavy teaching load, caring for two small children, and suddenly becoming the primary caretaker for an ill and aging parent. You were my sounding board and encouraged me when I lost faith in myself and my abilities. I thank you, and I eagerly look forward to a new chapter of our lives. 
To my precious daughters, Faith and Grace. I want so much for you, and I hope that one day you will understand that any time I spent hunched over in front of my computer typing or editing rather than playing with you and watching Disney movies was rooted in my desire to be a good role model, provider, and mother. You were my inspiration to complete what I started. Every sacrifice that I have made, I have done with the two of you in mind. Mommy loves you to the moon and back.

To my heavenly father. You have bestowed upon me two gifts of Holy Spirit: the gifts of teaching and of knowledge. When I struggled with the decision to pursue this degree and the obstacles that life placed in my way, my husband—your son—poured into my spirit with an abounding message: "I can do all things through Christ, who strengthens me” (Philippians 4:13). Today, my cup runneth over with favor and continued blessings. Therefore, "I will extol the Lord at all times; his praise shall always be in my mouth” (Psalm 34:1). 


\title{
ABSTRACT OF THE DISSERTATION
}

\section{FACULTY PERCEPTIONS OF SELF-PLAGIARISM AND OTHER FORMS OF ACADEMIC DISHONESTY AMONG UNIVERSITY STUDENTS}

by

\author{
Carleen Vincent-Robinson
}

Florida International University, 2016

$$
\text { Miami, Florida }
$$

\section{Professor Benjamin Baez, Major Professor}

As university faculty are often required to police academic misconduct among students, their attitudes and beliefs toward misconduct warrant investigation, particularly as the failure to act may exacerbate the incidence of students’ unethical behaviors. Therefore, this descriptive study examined faculty perceptions of academic dishonesty among students, institutional support, and self-plagiarism using an electronic-mail questionnaire $(N=201)$ and assessed the academic environment, frequency of student misconduct, and severity of those behaviors.

Female faculty were more likely than male faculty to perceive high levels of cheating on exams $(p<.01)$, inappropriately sharing work $(p<.05)$, plagiarizing written assignments $(p<.01)$, and violating institutional integrity policies $(p<.01)$. They were also more likely than their colleagues to construe self-plagiarism as the failure to secure instructor-permission prior to recycling papers $(p<.05)$ or recycling previously submitted papers, in their entirety $(p<.05)$. Non-tenured faculty were more likely than tenured 
faculty to identify recycling written assignments without permission, $(p<.05)$ and turning in a previously submitted group assignment as an individual assignment as selfplagiarism $(p<.05)$. They were also more likely than tenured faculty to perceive administrators $(p<.05)$ and deans $(p<.01)$ as supportive and encouraging in their quest to halt academic misconduct.

Additionally, online faculty were more likely than campus-based faculty to perceive higher levels of plagiarism among graduate students $(p<.05)$. Last, undergraduate faculty were more likely than graduate faculty to understand academic integrity policies $(p<.05)$.

Multi-way frequency analyses revealed significant interactions between the perceptions concerning academic integrity policies, institutional support, and understanding of self-plagiarism, thereby, resulting in the rejection of the three null hypotheses of no association.

Overall, faculty remain troubled by self-plagiarism; their perceptions are mediated by gender and academic rank. Consequently, additional efforts should be made to educate instructional staff about the various forms of academic dishonesty including, but not limited to, self-plagiarism, double-dipping, and recycling; increase faculty understanding and awareness of misconduct; and encourage compliance with said policies. 


\section{TABLE OF CONTENTS}

CHAPTER

PAGE

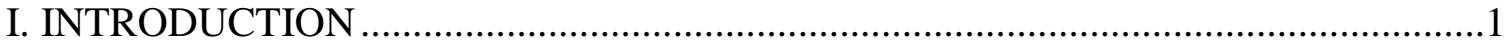

Situational Level Correlates of Academic Dishonesty ........................................2

Academic Major..................................................................................

Institutional Culture ............................................................................4

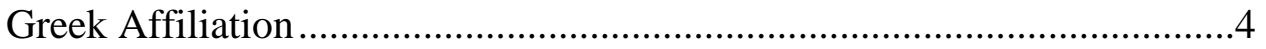

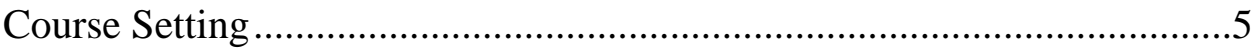

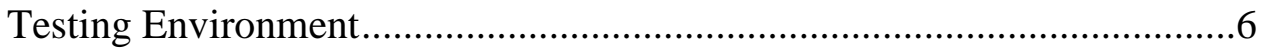

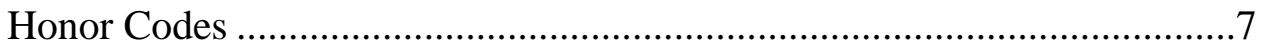

Individual Level Correlates of Academic Dishonesty .......................................8

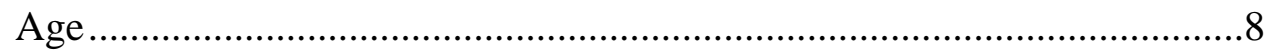

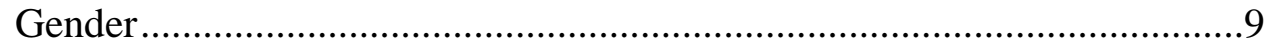

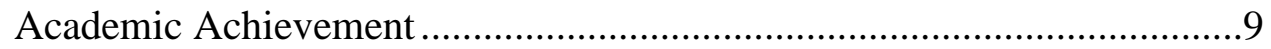

History of Academic Dishonesty ........................................................... 10

Attitudes Regarding Cheating ............................................................ 10

Attitudes Toward Faculty ......................................................................11

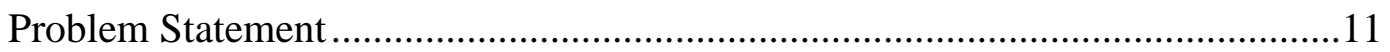

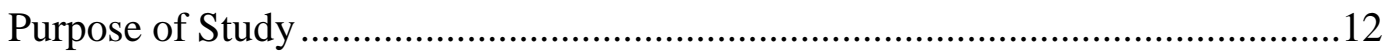

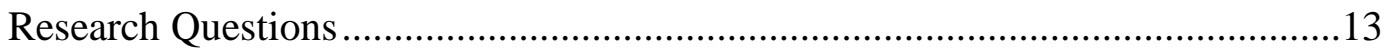

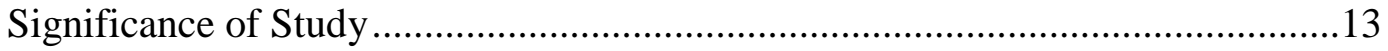

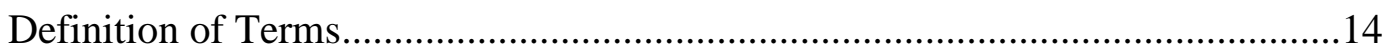

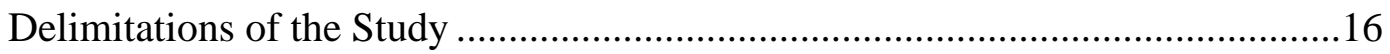

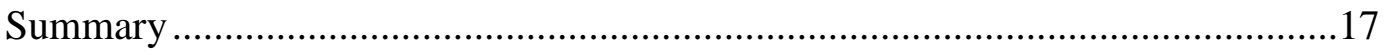

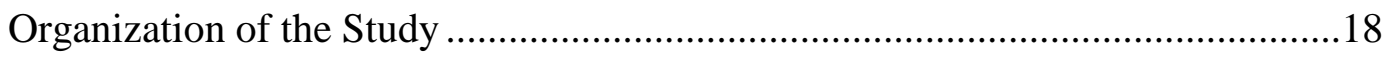




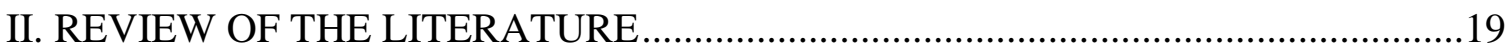

Conceptualizing Academic Dishonesty ..............................................................19

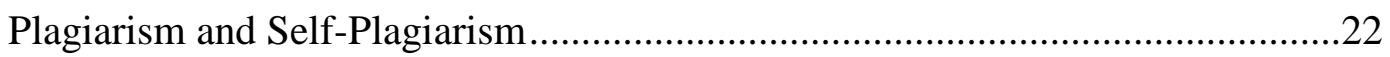

Factors Associated with Reporting Patterns Among Faculty ………………….....27

Emotional Factors ...................................................................................28

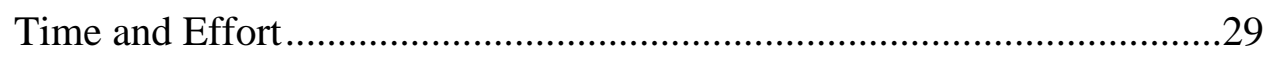

Denial of Academic Dishonesty ……………………….........................29

Perceptions of Institutional Support and Sanctions .....................................30

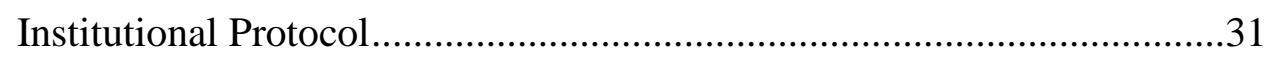

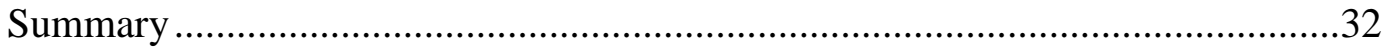

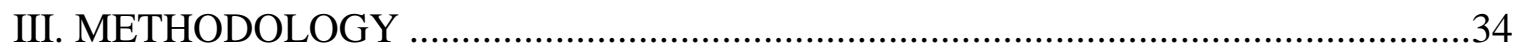

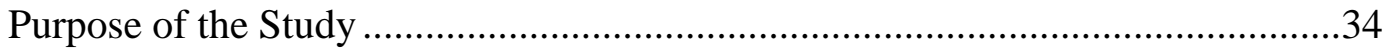

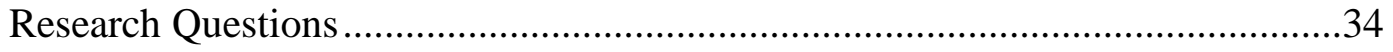

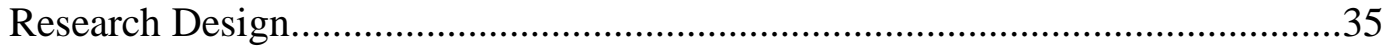

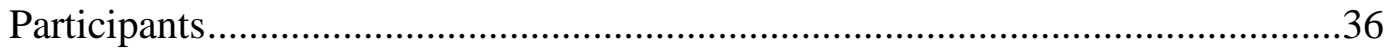

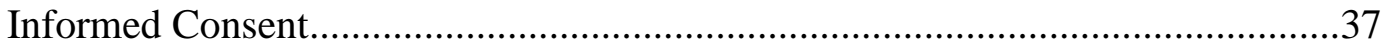

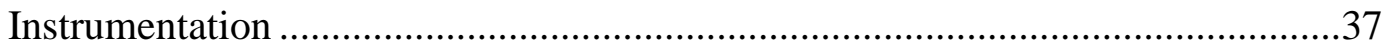

Survey Research Procedures............................................................................38

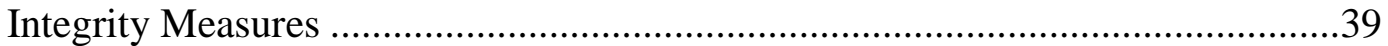

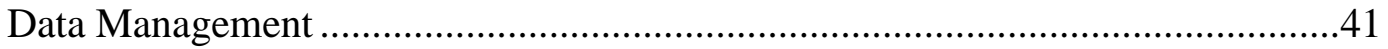

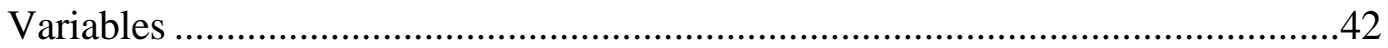

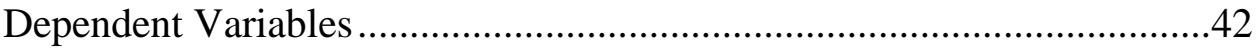

Independent Variables ...............................................................................43

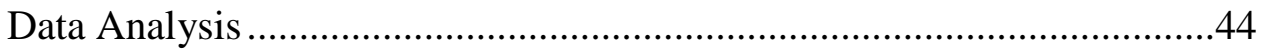

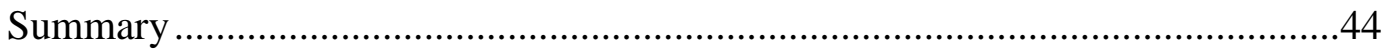

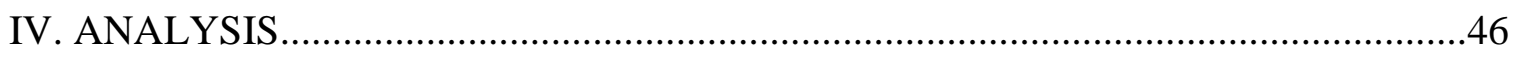

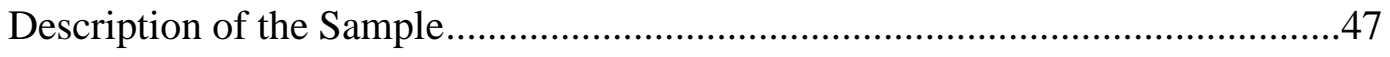

Perceptions of Student Behaviors ...............................................................50

Perceptions of the Seriousness of Academic Offenses ...............................52

Perceptions and Understanding of Academic Integrity Policies..................56

Perceptions of Institutional Support...........................................................58 


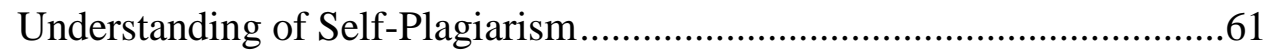

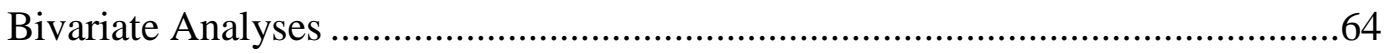

Perceptions of Academic Misconduct Among Students..............................64

Perceptions of Academic Integrity Policies .................................................72

Perceptions of Institutional Responses to Policy Violations .......................73

Understanding of Self-Plagiarism............................................................77

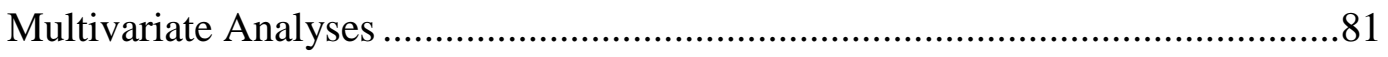

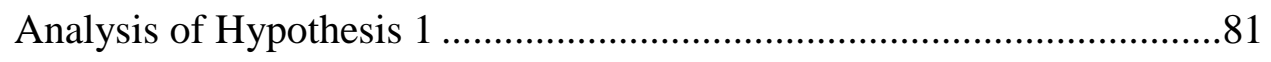

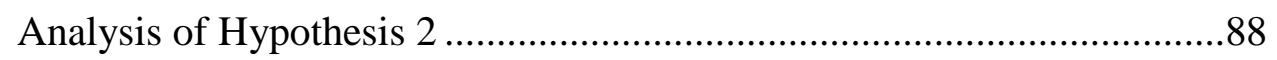

Analysis of Hypothesis 3 ………………………………........................92

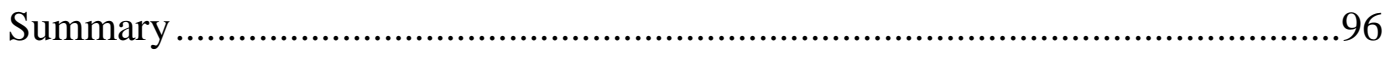

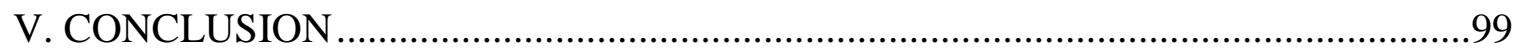

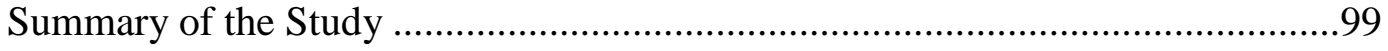

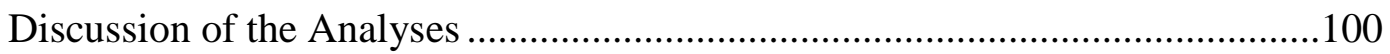

Research Question 1: How do university faculty perceive their institution’s academic integrity policies?....................................................100

Research Question 2: How do university faculty perceive their institution's responses to policy violations? ..............................................101

Research Question 3: How do university faculty understand self-

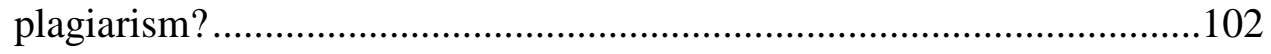

Limitations and Recommendations for Future Research.......................................107

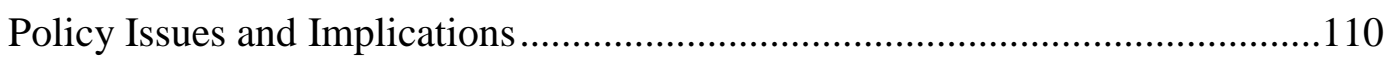

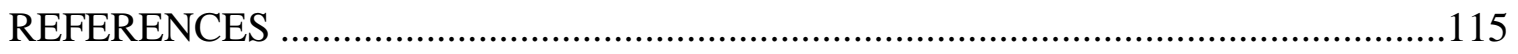

APPENDICES ……………………………………………………………....123

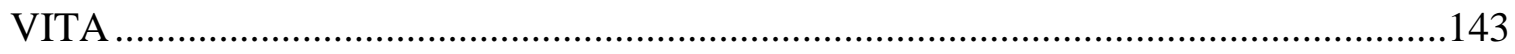




\section{LIST OF TABLES}

TABLE

PAGE

1. Prevalence of Cheating by Major in Honor Code and Non-Honor Code Schools........... 8

2. Univariate Analyses for Faculty Demographics

3. Univariate Statistics for Undergraduate and Graduate Student Engagement in

Academic Misconduct

4. Univariate Statistics for Perceptions of Seriousness of Academic Offense.

5. Univariate Statistics for Sources of Information for Academic Integrity Policies .57

6. Univariate Statistics for Perceptions of and Understanding of Academic Integrity

Policies. 58

7. Univariate Statistics for Perceptions of Institutional Support.

8. Univariate Statistics for Understanding Self-Plagiarism, Faculty Roles and Responsibilities, and Student Learning

9. Bivariate Results for Perceptions of Undergraduate Students Cheat by Faculty Rank, Course Setting, Level of Students Taught, and Gender 65

10. Bivariate Results for Perceptions of Undergraduate Students Plagiarize Written Assignments by Faculty Rank, Course Setting, Level of Students Taught, and Gender...66

11. Bivariate Results for Perceptions of Undergraduate Students Wrongfully Share Work by Faculty Rank, Course Setting, Level of Students Taught, and Gender ....

12. Bivariate Results for Perceptions of Undergraduate Students Violate Integrity Policies

by Faculty Rank, Course Setting, Level of Students Taught, and Gender .68

13. Bivariate Results for Perceptions of Graduate Students Cheat by Faculty Rank, Course Setting, Level of Students Taught, and Gender.

14. Bivariate Results for Perceptions of Graduate Students Plagiarize Written Assignments by Faculty Rank, Course Setting, Level of Students Taught, and Gender...70

15. Bivariate Results for Perceptions of Graduate Students Wrongfully Share Work by Faculty Rank, Course Setting, Level of Students Taught, and Gender.....

16. Bivariate Results for Perceptions of Graduate Students Violate Integrity Policies by Faculty Rank, Course Setting, Level of Students Taught, and Gender. 72 
17. Bivariate Results for Perceptions of Administrative Support by Faculty Rank, Course Setting, Level of Students Taught, and Gender

18. Bivariate Results for Perceptions of Dean Support by Faculty Rank, Course

Setting, Level of Students Taught, and Gender .75

19. Bivariate Results for Perceptions of Chair Support by Faculty Rank, Course Setting, Level of Students Taught, and Gender

20. Bivariate Results for Permission Needed to Recycle Previously Submitted Work

by Faculty Rank, Course Setting, Level of Students Taught, and Gender .78

21. Bivariate Results for Reusing Group Work by Faculty Rank, Course Setting, Level of Students Taught, and Gender.

22. Bivariate Results for Reusing Completed Paper is Self-Plagiarism by Faculty

Rank, Course Setting, Level of Students Taught, and Gender.....

23. Bivariate Results for Reusing Part of Previously Submitted Paper is

Self-Plagiarism by Faculty Rank, Course Setting, Level of Students Taught, and Gender.

24. K-way and Higher Order Effects for Faculty Understanding of Academic Integrity Policies.

25. Partial Associations for Faculty Understanding of Academic Integrity Policies. .84

26. Parameter Estimates for Faculty Understanding of Academic Integrity Policies .85

27. Goodness-of-Fit Tests for Faculty Understanding of Academic Integrity Policies.....85

28. Effective*Severity*Understanding Crosstabulation .86

29. Effective*Severity Crosstabulation .86

30. Effective*Support Crosstabulation .87

31. Severity*Support Crosstabulation

32. Understanding*Support Crosstabulation

33. K-way and Higher Order Effects for Faculty Perceptions of Institutional Support.....89

34. Partial Associations for Faculty Perceptions of Institutional Support .89

35. Parameter Estimates for Faculty Perceptions of Institutional Support .90

36. Goodness-of-Fit Tests for Faculty Perceptions of Institutional Support .90 
37. Administrationsupport*Chairsupport Crosstabulation

38. Administrationsupport*Deansupport Crosstabulation...............................................91

39. Chairsupport*Deansupport Crosstabulation .............................................................91

40. K-way and Higher Order Effects for Faculty Understanding of Self-Plagiarism ........94

41. Partial Associations for Faculty Understanding of Self-Plagiarism ............................94

42. Parameter Estimates for Faculty Understanding of Self-Plagiarism ...........................95

43. Goodness-of-Fit Tests for Faculty Understanding of Self-Plagiarism .........................95

44. Reuseall*Reusegroup Crosstabulation.......................................................................95

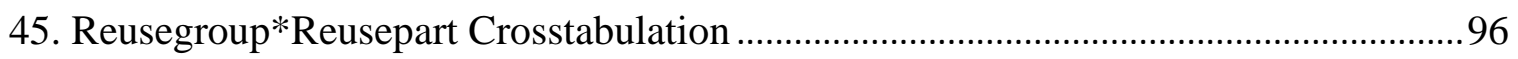

46. Chi-Square Table (Reusegroup*Reusepart) .............................................................96

47. Reuseall*Permission Crosstabulation ........................................................................ 96

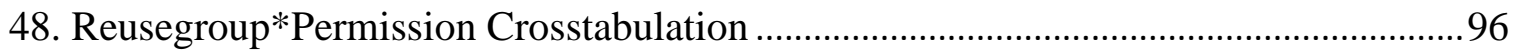




\section{CHAPTER I}

\section{INTRODUCTION}

Academic misconduct, “a transgression against academic integrity which entails taking an unfair advantage that results in a misrepresentation of a student's ability and grasp of knowledge” (King, Guyette, \& Piotrowski, 2009, p. 4), is perceived as commonplace among institutions of higher education. Certainly not a new phenomenon, student engagement in academically dishonest behaviors has increased considerably over the past 60 years (Graham, Monday, O'Brien, \& Steffen, 1994; McCabe \& Trevino, 1993; Whitley, 1998). Such behaviors may constitute the new norm in higher education (Vowell \& Chen, 2004), and, as such, warrant both increased attention and research

efforts directed at furthering instructors' understanding of academic dishonesty within the academy.

Although considerable attention has been brought to academic dishonesty (Kelley \& Bonner, 2005; Simkin \& McLeod, 2010), the vast majority of the literature on this topic addresses the prevalence of academically dishonest behaviors and students’ attitudes toward the same. For instance, Whitley’s (1998) meta-analysis of 107 studies published from 1970 to 1996 revealed that $70 \%$ of undergraduate students admitted to cheating on exams or plagiarizing written assignments. McCabe and Trevino (1993) found similar rates in their national study of approximately 6,100 undergraduate students, the majority of whom admitted that they had engaged in academic dishonesty during the course of their college careers. Moreover, a study conducted at the Duke University Center for Academic Integrity revealed undergraduates’ cheating patterns, where nearly 
$80 \%$ of students reported that they had engaged in academic dishonesty at least once (Kleiner \& Lord, 1999).

The results from these studies may be indicative of an "ethical deterioration" (Carnegie Council Report, 1979 as cited in Tom \& Borin, 1988, p. 153) within higher education such that academic misconduct may have seemingly shifted from an act of deviance to what some assert is "part of an overall pattern of norm violation" (Vowell \& Chen, 2004, p. 226). The prevalence rates suggest not only that academic dishonesty has reached epidemic proportions across campuses but that it has become an issue of institutional and national concern.

In an attempt to thwart academic dishonesty as part of the institutional culture, scholars have researched and uncovered many of the key determinants of academic misconduct. The most commonly cited determinants of academic dishonesty are found below and are separated into two overarching categories: situational level and individual level correlates.

\section{Situational Level Correlates of Academic Dishonesty}

\section{Academic Major}

Several researchers have attempted to identify correlations between students' academic major, career interests, and academic dishonesty. McCabe and Trevino (1993), for example, examined patterns of academic dishonesty among more than 6,000 undergraduate business students at 31 universities. They ascertained that nearly $90 \%$ of undergraduate business students and $76 \%$ of students (regardless of major) planning to enter fields in business after graduation had engaged in academically dishonest behaviors at least once. 
McCabe (1997) also assessed cheating trends by major. Using the data from the 1993 survey, he examined the frequency of specific cheating behaviors including copying from another student's exam with or without his or her knowledge, using crib sheets during an exam, helping a student cheat, plagiarizing a written assignment, fabricating or falsifying references, submitting another student's work as one's own, and failure to properly cite sources. Ultimately, he discerned that "higher levels of cheating ... [were] found in the more vocationally oriented majors of business and engineering[.] In contrast self-reported cheating among natural science majors ... [was lower and] generally comparable to students majoring in the social sciences and humanities” (McCabe, 1997, p. 439).

In addition, the ethical behaviors of criminal justice students have been extensively reviewed. In their 1993 study, Eskridge and Ames discerned minimal differences in academically dishonest behaviors among criminal justice and non-criminal justice students. All students, regardless of their majors, were equally as likely to have taken part in academic misconduct while in college (Eskridge \& Ames, 1993). Coston and Jenks (1998) also directed their research efforts toward the unethical behaviors of criminal justice students and discovered that the majority of them had either planned to or had already used a peer's notes to prepare for an examination, discussed an assessment with another student who had already taken the exam, or copied another student's assignment.

Last, Lambert and Hogan (2004) assessed academic dishonesty among criminal justice undergraduate students and compared their behavior to non-criminal justice majors. They determined that criminal justice students were more likely than non- 
criminal justice students to take exams for their peers. They were, however, less likely to have submitted group work for an individual assignment, to make up sources or list unused sources on a bibliography, or to review unauthorized copies of exams.

\section{Institutional Culture}

Students continue to maintain that dishonesty is common among their peers (Simkin \& McLeod, 2010) and assert that social norms do not prohibit cheating (Haines et al., 1986; Lanza-Kaduce \& Klug, 1986; McCabe \& Trevino, 1993, 1996, 1997; Michaels \& Miethe, 1989; Whitley, 1998). As such, students claiming that cheating is part of the institutional culture may be more likely to engage in dishonest behaviors than those who do not hold such beliefs (Yardley, Rodriguez, Bates, \& Nelson, 2009). Additionally, students engaged in academic misconduct may discover that academic integrity policies are neither strictly nor consistenly enforced. Therefore, they may conduct cost-benefit analyses assessing the risk of punishment and the benefit of passing or obtaining good grade. Situations where the risk of punishment is low, in turn, may encourage dishonest behaviors among students (Hutton, 2006).

\section{Greek Affiliation}

The literature reveals that student participation in extra- or co-curricular activities correlates with their engagement in unethical behaviors (McCabe \& Trevino, 1997; Whitley, 1998). Membership in Greek organizations, in particular, is positively correlated with academic dishonesty (Baird, 1980; Haines et al., 1986; Lambert \& Hogan, 2004; McCabe \& Bowers, 1996; McCabe \& Trevino, 1997; Stannard \& Bowers, 1970; Whitley, 1998). This may be the result of minimum grade point averages (GPAs) required for participation in these social organizations (Kelley \& Bonner, 2005; King et 
al., 2009). In their 1996 study, McCabe and Bowers, for example, suggested that sorority women received considerable academic pressure from their sorority sisters and, thus, were more likely to cheat than non-sorority students. Sorority members applied academic pressure because their chapter GPAs were at risk which, in turn, affected chapter eligibility. Williams and Janosik (2007) also examined academic misconduct among sorority women and determined that freshmen who were interested in Greek membership engaged in academic dishonesty more than their non-interested peers. The same was true for upper-class sorority members; they were more likely to engage in academic misconduct than upper-class women who lacked interest in Greek life.

The increased probability for engaging in misconduct may be associated with peer behaviors (Lanza-Kaduce \& Klug, 1986; McCabe \&Trevino, 1996, 1997) or the appeal to higher loyalties (Sutton \& Huba, 1995), both of which may influence students’ decisions to cheat. Furthermore, it is important to note that "[a]s relationships become more dense, pressure to help friends may be especially high” (Hensley, 2013, p. 25). Consequently, students who participate in extra- or co-curricular activities may prioritize membership and participation over academics (McCabe \& Bowers, 1996; McCabe \& Trevino, 1997; Williams \& Janosik, 2007) and, as a result, may feel pressured to cheat to maintain their eligibility (Lambert \& Hogan, 2004).

\section{Course Setting}

Course setting may play a role in whether or not students engage in academically dishonest behaviors. A review of the literature reveals that students and faculty, alike, perceive academic misconduct as commonplace in the online environment relative to the brick-and-mortar classroom (Grijalva, Nowell, \& Kerkvliet, 2006; King et al., 2009). 
This is due, in part, to the belief that "online learners purportedly lack direct interaction with their instructors, which breeds feelings of isolation as well as perceptions of inaccessibility and distance” (Kennedy et al., 2000 as cited in Robinson, 2013, p. 190). These feelings may facilitate the ease with which online students engage in academically dishonest behaviors (Bailey \& Baily, 2011; Kennedy et al., 2000).

In addition, online students may not understand academic dishonesty in the same fashion as their on-campus peers (Bailey \& Bailey, 2011). In a 2009 study, King and colleagues reported that the beliefs of business students $(N=121)$ taking an online exam varied based upon the instructor's academic misconduct policies. Behaviors that most on-campus students would not engage in during an examination (i.e., accessing books, references, and/or class notes) were considered appropriate by the online students if the instructor lacked the foresight to include such explicit language in the course policies. Kennedy and colleagues (2000) found similar results, noting that online students failed to appreciate the academic traditions of the classroom. Moreover, younger students seemingly failed to understand the appropriate use of online materials within the online setting (Bailey \& Bailey, 2011; Conway-Klaassen \& Keil, 2010), perceiving online materials as "subject to fair use” (King et al., 2009). Accordingly, students’ perceptions of behaviors inside and outside of the classroom may be subject to contextual variations (Bailey \& Bailey, 2011).

\section{Testing Environment}

Research has indicated that the structure of the testing environment is associated with a student's likelihood to engage in academic dishonesty. Students may be more likely to cheat if they believe that the risk of being caught is minimal (McCabe \& 
Trevino, 1993; Michaels \& Miethe, 1989). Hence, opportunities for academic misconduct may increase on unproctored exams (Sierles, Kushner, \& Krause, 1988). Additionally, students seated next to their friends may engage in academic misconduct with greater frequency than if they are seated next to strangers or if there is an empty seat next to them (Houston, 1986). Thus, the structure of the testing environment may be significant when students perceive the grade received as more important than the overall learning process (Houston, 1977).

\section{Honor Codes}

Honor codes have existed within the academy for more than a century (McCabe \& Trevino, 1993) and typically contain features including, but not limited to, “(a) a written pledge of academic honesty, (b) student involvement in the judiciary process of hearing cases of alleged academic dishonesty, (c) unproctored exams, and (d) the requirement of students to report suspected cases of peers’ dishonesty” (Dufresne, 2004, p. 202). Several studies have determined that the presence of an honor code is negatively associated with student engagement in academic misconduct. For example, McCabe (1997) evaluated the relationship between the presence of honor codes and academically dishonest behaviors of undergraduate students on campuses around the nation. He discerned that academic dishonesty occurred with less frequency at universities with honor codes relative to those without codes. More specifically, his findings revealed that $62 \%$ of business students, $29 \%$ of engineering students, $31 \%$ of natural sciences students, and 39\% of social sciences students attending institutions with honor codes engaged in academic dishonesty on examinations compared to $85 \%$ of business students, $68 \%$ of engineering students, $60 \%$ of natural sciences students, and $63 \%$ of social sciences 
students attending institutions without honor codes (See Table 1). These findings, however, may be the result of "greater normative pressure to avoid cheating on students at honor code schools” (Whitley, 1998, p. 253) and the efficacy of honor codes at “explicitly defin[ing] dishonest behavior, increas[ing] the likelihood of detecting academic dishonesty, and increas[ing] the awareness of the sanctions for cheating” (Dufresne, 2004, p. 202).

Table 1 Prevalence of Cheating by Major in Honor Code and No Honor Code Schools.

\begin{tabular}{lrr}
\hline & Honor Code & No Honor Code \\
\hline Major & & \\
Business & $62 \%$ & $85 \%$ \\
Engineering & $29 \%$ & $68 \%$ \\
Natural Sciences & $31 \%$ & $60 \%$ \\
Social Sciences & $39 \%$ & $63 \%$ \\
\hline
\end{tabular}

Despite research showing that honor codes may be inversely related to academic dishonesty, the extent of the code's deterrent effect continues to be debated. After reviewing perceptions and behaviors of students at three universities, Hall and Kuh (1998) ascertained that honor codes mildly deterred dishonest behaviors and that institutions desiring a reduction in the prevalence of academic dishonesty among student populations require both an honor code and an institutional culture that foster and encourage academic integrity.

\section{Individual Level Correlates of Academic Dishonesty}

\section{Age}

A review of the literature reveals that age is negatively correlated with unethical conduct among students. Therefore, older students may be less likely than their younger 
peers to engage in academically dishonest behaviors (Baird, 1980; Haines et al., 1986; McCabe \& Trevino, 1997; Michaels \& Miethe, 1989; Whitley, 1998). This may be the result of increased maturity or the ability to appreciate the seriousness of academic endeavors as well as the consequences of violating institutional policies.

\section{Gender}

The association between gender and misconduct remains unclear. While some researchers have failed to find statistically significant relationships between gender and academic dishonesty (Diekhoff et al., 1996; Haines et al., 1986; Houston, 1983), those asserting that gender was associated with the decision to engage in academic misconduct allege that the differences result from the ways in which men and women are socialized. More specifically, "[w]omen have been socialized to obey rules, whereas the socialization of men is less insistent in this regard" (Ward \& Beck, 1990, p. 333). As such, men are presumed to engage in unethical behavior more frequently than their female counterparts (Baird, 1980; McCabe \& Trevino, 1997; Michaels \& Miethe, 1989; Whitley, 1998). Yet, several scholars have discovered an increase in the number of women now engaging in academically dishonest behaviors (Graham et al., 1994). This surge may be related to the rise of women registering for and enrolling in maledominated majors and, thus, yielding to pressure to compete with their male peers (McCabe \& Trevino, 1996).

\section{Academic Achievement}

Not surprisingly, academic achievement levels are associated with academic dishonesty (Simkin \& McLeod, 2010). More specifically, grade point average is negatively correlated with participating in academically dishonest behaviors. Students 
with higher GPAs may be less likely than their peers with lower GPAs to report engaging in academic misconduct (Haines et al., 1986; McCabe \& Trevino, 1997; Whitley, 1998). It is possible that students with higher GPAs possess greater academic skills and, as such, are neither tempted to cheat (Lambert \& Hogan, 2004) nor willing to risk the types of losses associated with academic dishonesty (i.e., peer approval and scholarships). Consequently, they refrain from such behaviors (McCabe \& Trevino, 1997).

Nevertheless, the converse is also true: students with lower GPAs may have "less to lose and more to gain by engaging in academic dishonesty” (Lambert \& Hogan, 2004, p. 2) and, thus, may be more likely than their counterparts to engage in such behaviors (Baird, 1980; Graham et al., 1994; Roig \& DeTommaso, 1995). These behaviors, in fact, may encompass "a viable strategy for earning a good grade at any cost ... [or constitute] a useful strategy for demonstrating, albeit falsely, that the student is competent in a particular domain” (Anderman, Griesinger, \& Westerfield, 1998, p. 84).

\section{History of Academic Dishonesty}

A student's prior history of academic dishonesty is positively correlated with future misconduct. Individuals who admit to engaging in academically dishonest behaviors in secondary school or while attending postsecondary institutions may be more likely than their non-cheating counterparts to report engaging in the same types of behavior in college, graduate, or professional schools, respectively (Whitley, 1998).

\section{Attitudes Regarding Cheating}

Students who believe that social norms do not prohibit cheating may be more likely than those lacking such beliefs to engage in academically dishonest behaviors (Haines et al., 1986; Lanza-Kaduce \& Klug, 1986; McCabe \& Trevino, 1993; Michaels 
\& Miethe, 1989; Whitley, 1998). These perceptions and beliefs often result from neutralization techniques (Haines et al., 1986; Sykes \& Matza, 1957). Positively associated with academic dishonesty, neutralizing techniques allow individuals to justify their behaviors despite knowing such behaviors to be unethical or violative of institutional integrity policies (Rettinger \& Kramer, 2009; Sykes and Matza, 1957). For instance, students may claim ' 'I'll never need to use this material' and 'Everyone else is doing it'” (O’Rourke et al., 2009, p. 49) to justify their actions. They may also rationalize their behaviors and shift blame to external forces such as faculty and peers (O’Rourke et al., 2009). As a result, students are able to deny any injury or the existence of a victim, asserting, instead, that academic dishonesty is a victimless offense (Sykes and Matza, 1957, 1994). Hence, students, irrespective of whether or not they are caught, may justify their actions and minimize the seriousness of their infractions.

\section{Attitudes Toward Faculty}

Students' attitudes toward faculty may also play an important role in their behaviors. For instance, undergraduate students frequently assert poor accessibility to and/or poor relationships with faculty as justifications for engaging in academic misconduct (Kelley \& Bonner, 2005). In addition, those students who perceive faculty as apathetic toward the assignment, the topic, (Comas-Forgas \& Sureda-Negre, 2010), and the student (Park, 2003) may be more likely than peers lacking these beliefs to engage in academically dishonest behaviors.

\section{Problem Statement}

Acts of academic dishonesty are perceived as commonplace on university campuses nationwide; as such, many studies have reviewed the prevalence of academic 
dishonesty among college students (King et al., 2009; Kleiner \& Lord, 1999; McCabe \& Bowers, 1994; Whitley, 1998). Despite the considerable amount of research conducted, limited attention has been directed toward instructors' perceptions and understanding of academic dishonesty. National data indicate that "[s]eventy-one percent of [faculty] strongly or generally agreed that confronting cheating students is one of the most negative aspects of the teaching profession” (Keith-Spiegel, Tabachnick, Whitley, \& Washburn, 1998, p. 224). As such, faculty may be reluctant to address or report academic dishonesty which, in turn, may increase their perceptions of unethical behaviors. Continued research efforts, therefore, are needed to investigate how faculty understand and perceive academic dishonesty as the perceptions may have significant policy implications as well as affect university practices.

\section{Purpose of Study}

My assumption that university students regularly engage in academically dishonest behaviors serves as the point of departure for this study. As such, I assume that faculty not only possess the skills necessary to teach their students but that they also actively engage in creating positive learning environments and fair assessment methods. Accordingly, this descriptive study assessed faculty perceptions of academic integrity. I surveyed university-level faculty to determine how they perceived and understood academic dishonesty at their respective institutions. I determined perceptions via the participants' rating of the institution's academic environment, assessment of student involvement in academically dishonest behaviors, and opinions of institutional support when confronting academic dishonesty. I ascertained levels of understanding via faculty 
knowledge of institutional policies and the identification of articulated behaviors as selfplagiarism.

\section{Research Questions}

The study was guided by the following research questions:

1. How do university faculty perceive and understand their institutions' academic integrity policies?

2. How do university faculty perceive their institutions' responses to policy violations?

3. How do university faculty understand self-plagiarism?

Several subordinate questions were also of importance:

1. Do the perceptions of university faculty vary by certain demographics?

2. Do the perceptions of university faculty vary across course setting?

3. Do the perceptions of university faculty vary in accordance with the academic level of students taught?

4. Do the perceptions of university faculty vary by gender?

\section{Significance of Study}

I selected academic dishonesty as a topic of study upon discovering the variations

within my colleagues’ interpretations of what behaviors constituted academic dishonesty and what sanctions were appropriate for violations of the institutional academic integrity policies. This study bears significance for several reasons. A review of the literature reveals that a considerable number of faculty (approximately 40\%) ignore cheating behaviors (Coren, 2011); yet, ignoring academic dishonesty may exacerbate the problem by confusing students regarding which behaviors faculty perceive as appropriate or 
inappropriate (Volpe et al., 2008). As faculty attitudes and behaviors may influence student engagement in academically dishonest behaviors, the variations in their attitudes and beliefs warrant investigation.

Most academic dishonesty studies are conducted on a single campus whereas this study compared multiple public institutions of higher education in the state of Florida. As no studies were found that assessed faculty perspectives at minority-serving institutions, the targeted population of this study included a Hispanic-serving institution, a historically black college/university, and multiple predominantly white institutions. Most importantly, the majority of available studies focus on the attitudes and behaviors of undergraduate students whereas the current study assessed faculty perceptions and understanding of academic integrity policies and behaviors of students at varying academic levels (i.e., undergraduate versus graduate) and who are taught in a variety of settings (i.e., fully online; hybrid; face-to-face).

Consequently, the findings from this study will facilitate a greater understanding of faculty perceptions regarding academic integrity policies and institutional support. This information may be important to instructional staff who are responsible for the development and implementation of academic integrity policies and procedures, both, within and outside of the classroom.

\section{Definition of Terms}

The following section provides definitions of terms to ensure consistency and facilitate the reader's understanding. I developed the definitions not accompanied by a citation. 
Academic integrity: "A commitment even in the face of adversity, to five fundamental values: honesty, respect, trust, fairness, and responsibility” (International Center for Academic Integrity, 2012, para. 1).

Academic integrity policy: A policy created by an institution of higher education that establishes ethical standards to which all members of the institutional community will be held.

Academic dishonesty: "A transgression against academic integrity which entails taking an unfair advantage that results in a misrepresentation of a student's ability and grasp of knowledge” (King et al., 2009, p. 4).

Cheating: "Any action that violates the established rules governing the administration of a test or completion of an assignment; a behavior that gives one student an unfair advantage over other students on a test or assignment; or an action that decreases the accuracy of the intended inferences arising from students' performance on a test or assignment” (Cizek, 2003, p. 3).

Double-dipping: "[W]hen a student submits a whole paper or a substantial portion of a paper to fulfill a course requirement, even though that paper had earlier been submitted to satisfy the requirements for another course taught by a different professor” (U.S. Department of Health \& Human Services, 2011).

Faculty/Instructor: An individual whose primary role at an institution of higher education is related to teaching.

Institution of higher education: A public college or university accredited by a state agency. 
Plagiarism: “The public misrepresentations of work as original, or any activity in which a person knowingly or unknowingly and for some form of gain, represents the work of another as his/her own” (Robinson-Zanartu \& Pena, 2005, p. 319).

Recycling: “To use again in the original form or with minimal alteration” (recycle, 2016).

This is not be confused with scaffolding.

Self-plagiarism: The submission of previously submitted material for evaluation by faculty or, for published works, “presenting one’s own previously published work as though it were new” (American Psychological Association, 2010, p. 170).

\section{Delimitations of the Study}

The primary delimitation of this study involved the perception that students regularly engage in academic misconduct. As such, the role of faculty in possibly creating and/or fostering environments where students regularly fail or are somehow forced to cheat in order to pass was not acknowledged; to the contrary, I assumed that faculty actively desire and engage in behaviors promoting positive learning environments, student-faculty relationships, and fair assessment methods. The next delimitation involved excluding the perceptions of university administrators holding courtesy faculty appointments, institutional staff whose annual assignments were specifically related to dealing with students accused of academic dishonesty, part-time or adjunct faculty, and students. Although each of the aforementioned groups may have presented different perspectives affecting faculty perceptions of student academic misconduct, none were included in the study. The third delimitation involved the sites chosen. Florida was the only state selected for review. The fourth delimitation concerns the type of educational institutions included in the study. Although only faculty 
employed at four-year public institutions were considered, these individuals may not reflect the perceptions of faculty employed by private institutions or at colleges and universities nationwide.

\section{Summary}

The perceived occurrence of academic dishonesty across the nation's universities is cause for national concern (Diekhoff et al., 1996; Haines et al., 1986; Kleiner \& Lord, 1999; McCabe \& Trevino, 1993; Whitley, 1998). An examination of the literature reveals that postsecondary students are perceived to engage in academic dishonesty with such frequency that the previously aberrant behavior may simply be "part of an overall pattern of norm violation” (Vowell \& Chen, 2004, p. 226) constituting the collegiate experience. In Chapter I, I reviewed the primary correlates of academic dishonesty. The correlates, which were separated into individual and situational factors, included age, gender, academic achievement, history of dishonesty, attitudes toward dishonesty, attitudes towards faculty, academic major, institutional culture, group membership, the testing environment, and the presence of honor codes. Age (Haines et al., 1986; McCabe \& Trevino, 1993; Whitley, 1998), academic achievement (McCabe \& Trevino, 1993; Whitley, 1998), and the presence of honor codes (McCabe, 1997; McCabe \& Trevino, 1993) were negatively correlated with academic dishonesty. As each of the aforementioned variables increased, the likelihood of engaging in academic dishonesty decreased. On the other hand, prior history of academic dishonesty, poor attitudes toward dishonesty, academic major, and group membership (Haines et al., 1986; McCabe \& Trevino, 1993; Whitley, 1998) were positively correlated with academic dishonesty; 
therefore, students who had attitudes favorable toward dishonesty or who participated in Greek organizations were more likely to engage in academically dishonest behaviors.

\section{Organization of the Study}

Chapter I included an introduction to academic dishonesty among university students, the problem statement, and the purpose statement. In addition, I discussed the significance of the study, definitions of terms, and delimitations. The following chapters review the most current and pertinent literature related to faculty perceptions of academic dishonesty, the study’s methodology, analysis, and conclusion. 


\section{CHAPTER II}

\section{REVIEW OF THE LITERATURE}

Despite the quantity of research that has been conducted regarding the prevalence of academic dishonesty, a gap exists in the literature regarding instructors’ perceptions of students’ misconduct. This descriptive study attempted to narrow the gap by examining the following questions: (a) how do university faculty perceive their institution's academic integrity policies; (b) how do university faculty perceive their institution’s responses to policy violations; and (c) how do university faculty understand selfplagiarism. Therefore, the following section reviews major studies that have explored instructors' beliefs related to plagiarism, one of the most common forms of academic dishonesty. Then, the factors associated with instructors' decisions to report students' unethical conduct will be examined.

\section{Conceptualizing Academic Dishonesty}

Although scholars regularly document instances of academic dishonesty and cheating, in particular, researchers have failed to develop widely accepted definitions of either term (Pincus \& Schmelkin, 2003). As such, definitions often vary in the articulation of proscribed behaviors. Maramark and Maline (1993), Keith-Spiegel and colleagues (1998), and Cizek (2003), for example, provide three vastly different definitions of cheating, all of which affect how faculty and students understand academic dishonesty. To begin, Maramark and Maline (1993) claimed that “[c]heating takes many forms - from simply copying another student's paper to stealing an exam paper to forging an official university transcript” (p. 3) while Keith-Spiegel and colleagues (1998) described cheating as "a covert activity with effort (that is not always successful) made 
by the dishonest student to avoid detection” (p. 222). Cizek (2003), on the other hand, defined cheating as:

Any action that violates the established rules governing the administration of a test or completion of an assignment; a behavior that gives one student an unfair advantage over other students on a test or assignment; or an action that decreases the accuracy of the intended inferences arising from students' performance on a test or assignment. (p. 3)

The aforementioned definitions describe an assortment of behaviors that fall within the purview of academic dishonesty. Academic dishonesty, in turn, may be defined as:

An intentional act of fraud, in which a student seeks to claim credit for the work or efforts of another without authorization, or uses unauthorized materials or fabricated information in any academic exercises. We also consider academic dishonesty to include forgery of academic documents, intentionally impeding or damaging the academic work of others, or assisting other students in acts of dishonesty. (Gehring \& Pavela, 1994, p. 5)

The failure to develop a uniform definition may cause considerable difficulty for the faculty and staff charged with disciplining students for alleged ethical violations. Although certain behaviors are regularly considered as dishonest (i.e., copying from another student's exams, purchasing papers, and stealing exams), other behaviors (i.e., submitting one writing assignment for more than one course or collaborating without permission on an assignment) remain ambiguous and controversial (Pincus \& Schmelkin, 2003; Schmelkin, Gilbert, Spencer, Pincus, \& Silva, 2008). 
Higbee and Thomas' (2002) exploratory study is a prime example of the varying perceptions of academically dishonest behaviors and illustrates the potential problems associated therewith. They surveyed both faculty $(N=251)$ and students $(N=227)$ at a large southeastern public university and asked them to indicate if 25 behaviors "less commonly perceived" as dishonest actually constituted cheating. Several of their findings warrant discussion. First, $80 \%$ of faculty indicated that talking to a student who had already completed an exam about the exam's content constituted cheating; however, $19 \%$ of the faculty disagreed. Additionally, a significant proportion of faculty asserted that reading summaries (39\%) or watching a video in lieu of reading the assigned text (41\%) amounted to academic dishonesty. Not surprisingly, the majority of faculty believed that student collaboration on an assignment (55\%) or asking one another for assistance on an assignment was not academically dishonest (74\%); however, several faculty experienced difficulty categorizing this behavior as "not cheating." In fact, 37\% of the faculty indicated that collaboration could amount to cheating as could asking for assistance on an assignment (18\%); yet, the classification would ultimately depend upon the assignment's instructions, the previously established class rules and customs, and whether the students actually collaborated or simply copied from one another.

In addition, Higbee and Thomas (2002) questioned instructors regarding the appropriateness of a student submitting the same written assignment for more than one course. Slightly less than $50 \%$ of the faculty considered multiple submissions to be a form of academic dishonesty, $25 \%$ did not perceive it as academically dishonest, and the remaining faculty responded that their classification of the behavior would depend upon certain factors including whether the student had secured the instructor's permission 
(15\%) and whether the essay actually met the requirements for both courses (7\%).

Alternatively, some instructors claimed that submitting the same paper for two courses in different terms was permissible as long as the student made substantive changes or improvements to the text.

\section{Plagiarism and Self-Plagiarism}

The vast majority of faculty would likely concur that academic dishonesty encompasses plagiarism. However, a careful review of the literature indicates that plagiarism may very well entail much more than "the public misrepresentations of work as original, or any activity in which a person knowingly or unknowingly and for some form of gain, represents the work of another as his/her own” (Robinson-Zanartu \& Pena, 2005, p. 319). Rather, it may consist of an assortment of behaviors including, but not limited to, omission of citations, improper use of citations, omission of quotation marks, submitting the work of another, and paraphrasing material without proper referencing. Hence, plagiarism, one of the most common forms of academic dishonesty, also lacks definitional uniformity and consensus (Park, 2003). As plagiarism “can undermine institutional credibility, produce conflicts between individuals and groups, and devastate the lives of those who report the offenses as well as those of the offenders” (RobinsonZanartu \& Pena, 2005, p. 319), continued research efforts are needed to further our understanding of how faculty perceive and respond to plagiarism.

In 2011, Bennett, Behrendt, and Boothby conducted a mixed methods exploratory study that examined university and college instructors' perceptions of plagiarism. Contacted via a set of electronic listservs, the faculty $(N=158)$ were questioned regarding seven possible forms of plagiarism, their experiences with plagiarism in their 
classes, the detection strategies used, and their responses to the same. The majority of instructors agreed that submitting another's work as one's own, failing to use quotation marks or cite material correctly, "acknowledging a source but changing very few words from a quote, paraphrasing material without acknowledging the source, and copying from one another while working in a group” (Bennett, Behrendt, \& Boothby, 2011, pp. 31-32) constituted plagiarism. There were considerable variations, however, in faculty perceptions of reusing previously submitted material—a concept commonly referred to as double-dipping or recycling. The instructors struggled with the concept, with $22 \%$ indicating that recycling was not plagiarism and 54\% asserting that such behaviors were academically dishonest.

Bennett and colleagues (2011) also reviewed predictors of perceiving recycling as inappropriate behavior. They ran a series of multiple regressions using demographics, experience with plagiarism, detection strategies, and responses to plagiarism as predictors. Three of the four overall models were not statistically significant. The last model, which used instructors' responses as predictors, was statistically significant, $F$ (9, 103 ) $=4.84, p<.001, R^{2}=.28$. Of the possible instructors' responses, two (doing nothing and reporting misconduct to university administrators) predicted instructors' perceptions of double-dipping where "having a tendency to do nothing in the face of plagiarism was associated with viewing recycling as appropriate, $[(\beta=-.27, p<.05)]$ but being likely to report an instance of plagiarism to a university committee was associated with viewing recycling as inappropriate $[(\beta=.39, p<.01)]$ ”" (Bennett et al., 2011, p. 33).

Using a convenience sample of instructors teaching introductory English and Speech courses, Marcus and Beck (2011) surveyed faculty $(N=14)$ at Queensborough 
Community College on their understanding of plagiarism to determine if faculty perceptions were aligned with the institution's Academic Integrity Plan. Although all of the faculty asserted that they understood what plagiarism entailed, their perceptions varied considerably. Seventy-two percent of instructors believed that stealing exams comprised an academic offense far worse than plagiarizing. Nearly one-fourth of the faculty asserted that undergraduates engaged in plagiarism should receive minimal punishment because they were novices at navigating the university environment. On the other hand, however, $21 \%$ of instructors stated that expulsion was an appropriate punishment for students purchasing papers online. Finally, $72 \%$ of the faculty declared that using a past assignment (in part or in toto) (i.e., double-dipping) for a new assignment did not constitute academic dishonesty. They reasoned that as plagiarism required the submission of another's work and the behaviors under consideration included a student submitting his or her own previously submitted material, plagiarism had not occurred. For the same reasons, they asserted that self-plagiarism was not feasible. Nevertheless, slightly more than one-fourth of the faculty disagreed, claiming that self-plagiarism did, in fact, constitute academic dishonesty.

Using a web-based survey, Halupa and Bolliger (2013) assessed faculty perceptions of student self-plagiarism and the recycling of previously submitted assignments. The faculty members $(N=89)$ from two private institutions answered questions about their understanding of self-plagiarism, institutional policies, student behaviors, and faculty responsibilities. The participants asserted that instructional staff did not clearly understood self-plagiarism (40\%); yet, the majority of the instructional staff believed they were responsible for teaching students about the concept. They also 
agreed that they should not assume that students had been taught about plagiarism and all of its forms in previous courses.

In addition, the instructors expressed their views regarding the advantages and disadvantages of self-plagiarism. Most of the faculty members concurred that students learn more through the scaffolding process (i.e., continuously building upon prior assignments), and approximately $53 \%$ of faculty members believed that utilizing a previously submitted assignment to complete a new assignment demonstrated timemanagement skills. Notwithstanding, 55\% of the faculty asserted that students who engaged in self-plagiarism were likely to experience difficulty with the instructional staff. Overall, the faculty agreed that self-plagiarism, in and of itself, was poorly understood and asserted that instructional staff should regularly enforce institutional academic integrity policies even though neither of institutions surveyed had specific policies addressing self-plagiarism in place.

Finally, Robinson-Zanartu and Pena (2005) surveyed 270 psychology graduate faculty to ascertain their exposure to and ability to deal with student plagiarism. Instructors were asked to assess 10 scenarios involving plagiarism. Using a generalized linear model, the instructors' perceptions of the behaviors as plagiarism were examined in conjunction with the amount of plagiarism, the source type (paper versus electronic), and how the plagiarized material was used. Prior experience dealing with plagairism was significantly related to the probability of judging uncited material as plagiarism. Additionally, the source of material was also significantly related to one's perception of academic dishonesty. For example, when compared to recycled writings, information obtained from the Internet was 8.89 times $(p<.0001)$ more likely to be considered 
plagiarism. The same was true for information obtained from paper sources which was 39.76 times $(p<.0001)$ more likely than recyclyed writings to be considered plagiarism. Several demographic variables were also significantly related to the perceived seriousness of the academic offense. Older faculty, instructors who self-identified as racial or ethnic minorities, and women were more likely to judge the scenarios more severely.

Overall, the instructors believed that punishments should be appropriate for the given offense. For instance, although the majority of the faculty members perceived small amounts of uncited material as plagiarism, they generally recommended less severe sanctions. Nearly $40 \%$ of faculty recommended that students guilty of plagiarizing a small amount should be permitted to resubmit the assignment. However, faculty proposed much harsher sanctions for students who plagiarized between 60 and $80 \%$ of their assignments. Approximately $30 \%$ of the faculty indicated they would report the student to the department chair, 30\% would report the student to university officials, $40 \%$ would recommend probation, and nearly half of the faculty reported that the student would be assigned a failing grade. Curiously, in instances where students engaged in self-plagiarism, $74 \%$ of faculty indicated that they would not report the student to university officials, 92\% believed that university sanctions should not be issued, and nearly one-third would take no action whatsoever. The majority of the faculty reported that they would discuss the issue with the student; yet, less than $20 \%$ would adjust the grade in accordance with the infraction.

As evidenced from the studies described above, faculty vary in their perceptions of academic dishonesty. This may be due, in part, to overly broad and vague behavioral 
definitions and classifications, the result of which may be discrepancies in whether sanctions or corrective treatment are appropriate consequences. As faculty have yet to arrive at a consensus regarding behaviors constituting academic misconduct, continued research efforts are required to increase "our understanding of how ... [they] perceive cheating and its seriousness” (Roberts \& Rabinowtiz, 1992, p. 189).

\section{Factors Associated with Reporting Patterns Among Faculty}

A review of the literature indicates that not all faculty consider student engagement in academically dishonest behaviors to be serious infractions that warrant official action and formal sanctions. According to Correnti:

At best [academic dishonesty] is dealt with unevenly; at worst it is avoided or totally ignored. If colleges and universities are to have an impact on value development, and I suggest they should, then a concerted effort by faculty and administrators must be undertaken in order to address the problem. (1986, as cited in Keith-Spiegel et al., 1998, p. 216)

Notwithstanding, a significant proportion of university faculty consistently ignore their students' academically dishonest behaviors. For instance, in their national assessment of university administrators, Aaron and Georgia (1994) ascertained that the majority (61.9\%) of university faculty ignored academic dishonesty and 40.9\% lacked familiarity with the institutional guidelines and academic integrity policies. In the same year, Graham and colleagues (1994) discerned minimal punitive actions initiated by faculty members who discovered student dishonesty at a Catholic institution of higher education. Although nearly $80 \%$ of faculty discovered academic misconduct, less than $10 \%$ initiated any type of disciplinary action. McCabe (2003) and Franklyn-Stokes and Newstead 
(1995) also found an overall lack of disciplinary action initiated against students who were caught engaging in academically dishonest behaviors. The most commonly cited factors associated with instructors' decisions to report academic dishonesty to university officials are found below.

\section{Emotional Factors}

National data indicate that faculty are hesitant to confront students engaged in academically dishonest behaviors. In fact, "[s]eventy-one percent of [faculty] strongly or generally agreed that confronting cheating students is one of the most negative aspects of the teaching profession” (Keith-Spiegel et al., 1998, p. 224). The negative aspects referred to are frequently rooted in the fear that a disgruntled student will either exact revenge or take other retaliatory measures against the professor (Keith-Spiegel et al., 1998; Mathur \& Offenbach, 2001). For example, in their survey of 272 faculty members and doctoral students, Mathur and Offenbach (2001) discovered that 10\% of faculty at Purdue University believed that reporting student academic dishonesty would bring about some form of retaliation.

Notwithstanding, other emotional factors such as the fear of low teaching evaluations resulting from reporting students to university officials and its effect on the tenure process (Keith-Spiegel et al., 1998) as well as the possiblity of litigation (Alschuler \& Blimling, 1995; Lester \& Diekhoff, 2002) may adversely affect the actions of instructional staff. Finally, faculty may also fear being accused of harassment and, as such, refrain from reporting unethical behavior (Staats, Hupp, Wallace, \& Gresley, 2009). 


\section{Time and Effort}

Some instructors assert that the process of gathering evidence against a student is difficult, burdensome, and time-consuming which, in essence, discourages them from reporting academic dishonesty (Alschuler \& Blimling, 1995; Groark, Oblinger \& Choa, 2001; Hughes \& McCabe, 2006; Keith-Spiegel et al., 1998; McCabe, 1993). More specifically, the time associated with reporting acts of academic dishonesty detracts from the limited time available to fulfill other required and, perhaps, more pressing institutional responsibilities such as research (Puka, 2005), teaching, and service (Coalter, Lim, \& Wanorie, 2007).

In addition, instructors may find reporting difficult because they often lack sufficient evidence or proof of the misconduct. For example, at institutions where plagiarism detection software such as Turnitin.com or Ithenticate are not regularly used, instructors may not be able to prove that a student plagiarized an assignment. In addition, instructors may not actually witness students engaging in the unethical behavior (i.e., using cheat sheets or unapproved technologies) during an exam and may confuse classroom behaviors commonly associated with cheating (e.g., looking around the room, glancing at another's paper, constantly moving around) with anxiety or restlessness (Keith-Spiegel et al., 1998). Thus, faculty who believe that there is a lack of evidence to prove their suspicions may be reluctant to report the suspected infraction (Keith-Spiegel et al., 1998; Staats et al., 2009).

\section{Denial of Academic Dishonesty}

Occasionally, some instructors will deny that academically dishonest behaviors occur within their classes and, as such, have nothing to report to university officials 
(Keith-Spiegel et al., 1998). However, other faculty not only deny the existence of academically dishonest behaviors in their classes but also construe those behaviors as learning opportunities. Professor Kevin Davis, a faculty member at East Central University located in Ada, Oklahoma is a prime example. In a 1992 article published in the English Journal, Davis described an epiphany that he experienced while proctoring an exam. He noted the following upon returning to his classroom to find students collaborating on the test:

I realized I wasn’t looking at cheaters; I was looking at collaborators. I wasn’t looking at students copying answers; I was looking at students solving problems. I wasn't looking at rapscallions sabotaging the educational system; I was looking at students preparing for successful lives in the real world. (Davis K., 1992, p. 74)

Clearly, the denial of academic dishonesty requires no additional action on the part of the faculty member.

\section{Perceptions of Institutional Support and Sanctions}

Other reasons that faculty are reluctant to report academically dishonest behaviors may include the negative experiences and/or perceptions of institutional support. KeithSpiegel and colleagues (1998) remarked:

Stories circulate about aggressively defensive students (or their parents) even when the evidence appears iron-clad, policies that uphold due process for students but fail to protect the faculty member acting in good faith, and unsupportive administrations that reverse the instructor's claims for reasons that appear to smack of expediency rather than a commitment to upholding institutional integrity. "I felt like I was the one on trial," said a distraught colleague after 
enduring a formal hearing wherein her own competency and character were questioned. (pp. 222-223)

Hence, faculty who perceive administrators as unsupportive may ignore the unethical behaviors of their students. The perception of a lack of support, however, is further confounded by the failure of administrators to consistently enforce policies (Williams \& Hosek, 2003) and the belief that previous punishments issued have been minimal or were inappropriate (Groark et al., 2001; Hughes \& McCabe, 2003; Lester \& Diekhoff, 2002; McCabe, 1993). Both examples give the impression that university officials do not support efforts to minimize ethical violations and, thus, may dissuade faculty from reporting any such infractions.

\section{Institutional Protocol}

Faculty perceptions of institutional protocol may also affect reporting patterns. In a study of the faculty at Texas A\&M University-Kingsville campus ( $N=109)$, Bennington \& Singh (2013) found that $54.1 \%$ of faculty planned to report future plagiarism to university officials, $55.9 \%$ reported that they would be more likely to address suspected acts of student plagiarism if there was an established procedure for faculty to follow, and $44 \%$ indicated that they would be more likely to file reports if a committee of faculty, students, and administrators adjudicated suspected acts of student plagiarism. Therefore, express procedures and policies would likely increase the

probability of faculty reporting students engaged in academically dishonest behaviors to university officials. 


\section{Summary}

In summary, Chapter II began with an introduction to academic dishonesty and how inconsistencies in the definition have affected study comparability as well as the understanding of prohibited behaviors. I examined instructors' understanding of plagiarism and self-plagiarism and reviewed the factors associated with reporting patterns among faculty.

Overall, faculty report some level of hesitation and discomfort when confronting academically dishonest students (Keith-Spiegel et al., 1998). Indubitably, some of these feelings stem from fear of low teaching evaluations resulting from reporting students, how reporting affects the tenure process (Keith-Spiegel et al., 1998), and the possiblity of litigation (Alschuler \& Blimling, 1995; Lester \& Diekhoff, 2002). Moreover, the time and effort associated with confronting and/or reporting a student may discourage faculty from reporting policy violations (Alschuler \& Blimling, 1995; Groark et al., 2001; Hughes \& McCabe, 2006; Keith-Spiegel et al., 1998; McCabe, 1993). Insufficient evidence of misconduct may also discourage reporting (Keith-Spiegel et al., 1998; Staats et al., 2009) as might prior negative experiences and/or perceptions of institutional support. Accordingly, faculty perceptions are worthy of further research.

As the results of the studies on faculty perceptions are limited, this dissertation contributed additional knowledge to the literature pertaining to faculty perceptions and understanding of academically dishonest behaviors including, but not limited to, selfplagiarism. Specifically, in this study, I moved beyond the descriptive statistics generally provided by faculty academic integrity surveys nationwide and contributed to the extant literature by using a more sophisticated statistical analysis to determine how 
faculty understand and perceive academic dishonesty. I assessed perceptions and understanding in terms of how faculty rated institutional academic integrity policies, the institutions' responses to student engagement in academically dishonest behaviors, and the identification of enumerated behaviors as self-plagiarism.

Chapter III provides a brief overview of the research methodology used to examine the research questions. 


\section{CHAPTER III}

\section{METHODOLOGY}

The results of the studies on faculty perceptions of academic dishonesty are

mixed. Nevertheless, institutional norms, attitudes toward, and interactions with faculty remain clearly important predictors of engagement in academically dishonest behaviors, and they may be important for faculty perceptions of academic dishonesty as well. In this study, I assessed faculty perceptions of academic integrity. More specifically, I determined what factors, if any, were correlated with faculty understanding and perceptions of academic integrity policies, levels of institutional support, and the identification of certain behaviors as self-plagiarism. In the following sections, I identified the research design, reviewed the sources of data, described variables of interest, and discussed my plans for analysis.

\section{Research Questions}

The study was guided by the following research questions:

1. How do university faculty perceive and understand their institutions' academic integrity policies?

2. How do university faculty perceive their institutions' responses to policy violations?

3. How do university faculty understand self-plagiarism?

Several subordinate questions were also of importance:

1. Do the perceptions of university faculty vary by academic rank?

2. Do the perceptions of university faculty vary across course setting? 
3. Do the perceptions of university faculty vary in accordance with the academic level of students taught?

4. Do the perceptions of university faculty vary by gender?

Accordingly, the following hypotheses were tested:

$\mathrm{H}_{1}$ : There is no relationship among the variables used to measure faculty perceptions of institutional academic integrity policies.

$\mathrm{H}_{2}$ : There is no relationship among the variables used to measure faculty perceptions of institutional responses to student engagement in academically dishonest behaviors.

$\mathrm{H}_{3}$ : There is no relationship among the variables used to measure faculty understanding of self-plagiarism.

\section{Research Design}

I used a survey to assess faculty understanding and beliefs regarding academic dishonesty as well as their perceptions of institutional response and support for addressing dishonesty. Survey research is appropriate when describing phenomena of interest and may be used to draw inferences from samples to populations, particularly those that are related to the opinions, attitudes, and trends of populations (Babbie, 1990; Creswell, 2003). This type of research can be completed using an assortment of questionnaires including traditional mail questionnaires, electronic mail surveys, and directly administered questionnaires (Ary, Jacobs, \& Sorenson, 2010). The present study was conducted using electronic mail surveys.

Electronic mail has been used to distribute surveys and collect data from online users for more than two decades (Sheehan, 2006). The advantages of e-mail surveys are 
numerous. First, e-mail surveys are typically less expensive than traditional mail surveys because paper and postage costs can be reduced or eliminated (Mavis \& Brocato, 1998; Sproull, 1986); as such, the costs to implement e-mail surveys may be $5-20 \%$ less than traditional mail surveys (Sheehan \& Hoy, 1999; Weible \& Wallace, 1998). Second, email surveys are associated with earlier completion (e.g., online submission) rates relative to postal surveys (Sheehan \& McMillan, 1999). Additionally, as electronic mail surveys do not require synchrony between the researcher and respondent (Best \& Krueger, 2002), they can be completed at the respondent's convenience (Ary et al., 2010). Moreover, email questionnaires are not subject to being misplaced as are traditional questionnaires (Ary et al., 2010), and they allow for "the transmission of text, graphics, and video ... [as well as] the targeting of specialized interests or population subgroups” (Best \& Krueger, 2002, p. 75). Finally, survey questionnaires are particularly useful when researching sensitive topics (Bachmann, Elfrink, \& Venzana, 1999) as telephone or face-to-face interviews may “yield inaccurate or incomplete responses” (Best \& Krueger, 2002, p. 75).

Notwithstanding, there are disadvantages associated with e-mail questionnaires. For instance, the misinterpretation of questions and the possibility that an individual will complete the questionnaire multiple times may adversely affect completion rates. Additionally, individuals lacking technological savvy or competence may experience difficulty with survey completion (Ary et al., 2010; Best \& Krueger, 2002).

\section{Participants}

The target population for the study consisted of university faculty employed at the 12 institutions of higher education within the Florida State University System. Four 
institutions did not respond to public records requests for faculty e-mails and two universities would not comply with the requests, citing solicitation concerns. As such, only the faculty from the remaining six institutions were invited to complete the survey.

A list of full-time instructional faculty from the remaining institutions was secured and used to generate a randomized list of faculty to be surveyed. Random sampling provided each faculty member with an equal probability of being included in the final sample (Ary et al., 2010; Creswell, 2003).

\section{Informed Consent}

Participants who chose to complete the e-mail questionnaire were required to read the online adult consent form and click on a "Consent to Participate/Next" button prior to beginning the survey (See Appendix A - Informed Consent Form). The form contained my contact information and detailed the study's purpose as well as the procedures, risks, concerns, benefits, and alternatives to participation. Participants were advised that survey completion required approximately 30 minutes of their time and that there were no known risks or direct benefits for participation. Participation had to be voluntary, and the individual could withdraw consent at any time. There was no compensation for participating. The only alternative to participation was the refusal to participate, for which there was no penalty. Anonymity was maintained as neither IP addresses nor email addresses were recorded.

\section{Instrumentation}

The study utilized McCabe’s Faculty Academic Integrity Survey (2003) and Halupa and Bolliger’s Faculty Perceptions of Self-Plagiarism Survey (2013) as the basis for a new instrument comprised of five sections (Appendix B). I secured permission 
from McCabe and Halupa to use and adapt their respective instruments for the proposed survey (See Appendix C - Permission to Use and Adapt Survey Instrument). Section I requested information about the perceived academic environment at the respondent's institution (i.e., student and faculty understanding and support of academic integrity policies, the seriousness of academic dishonesty, policy awareness, roles of faculty and students in combatting academic dishonesty, and faculty and administrative responses to dishonesty). Section II asked faculty to identify if they had ever observed students engaging in a list of enumerated behaviors and to rank the severity of the behavior. Section III assessed levels of agreement on faculty and student beliefs, understanding, and practices regarding self-plagiarism while Section IV questioned faculty about prevention measures implemented in their classes. Finally, Section V sought demographic information including the institution's Carnegie classification, the faculty member's academic rank, race, and gender, the number of years teaching in higher education, area of primary teaching responsibility, the academic level of students taught (i.e., lower-level undergraduate, upper-level undergraduate, or graduate students), and the course setting (i.e., on campus, hybrid, fully online).

\section{Survey Research Procedures}

I conducted the study using the electronic mail survey. Mertens' (1998) survey protocol governed the research process. Once I cleaned the sampling frame (e.g., removing ineligibles and duplicates from the list) and identified the sample, I sent an electronic cover letter to potential participants detailing the study's pupose and the participant's role in fulfilling that purpose. I provided the dates of survey availability, the means for maintaining confidentiality and handling data, and my contact information. 
One week later, I forwarded another letter (including the informed consent document) and a link to the questionnaire to the participant. I sent two follow up electronic e-mail reminders at one-week intervals to increase the response rate. Using IBM's SPSS version 20, I analyzed the survey data over the course of six weeks.

\section{Integrity Measures}

Survey research is subject to an assortment of biases that may affect the quality of the research and generalizability of the findings. Perhaps most important are the issues related to sampling frames and response rates. To begin, as e-mail addresses typically “do not appear in a comprehensive directory” (Best \& Krueger, 2002, p. 76), there can be considerable difficulty in acquiring a comprehensive and exhaustive list with each individual's correct e-mail address. Even institutional e-mail lists may not be accurate as faculty contracts may not be renewed. Therefore, diligence is required in attempting to secure or develop a sampling frame that includes the correct e-mail addresses for all members of the target population (Ary et al., 2010). To do otherwise threatens the generalizability of the findings (Babbie, 1990).

In addition, response rate is an issue of formidable concern for electronic mail surveys (Shannon \& Bradshaw, 2002) as they are considerably lower than mail surveys and, as such, warrant additional attention. I used several mechanisms to minimize nonresponse bias. First, as indicated above, I purged the sampling frame of duplicates and ineligible individuals. Next, I emphasized the study’s purpose and the issue of anonymity in the introduction letter and informed consent form; both documents were designed to appeal to the participant’s altruistic desires. Finally, I forwarded two electronic mail reminders to the participants. 
As noted above, I adapted McCabe’s (2003) Faculty Academic Integrity Survey and Halupa and Bolliger’s (2013) Faculty Perceptions of Self-Plagiarism Survey to construct the instrument for this study. Considered the father of academic integrity research, Donald McCabe has researched and written about academic integrity for more than two decades (Rutgers, The State University of New Jersey, 2014). His questionnaire, Faculty Academic Integrity Survey, has been used at dozens of universities across the nation to assess faculty perceptions of academic dishonesty and is thought to have high levels of reliability and validity. Halupa and Bolliger’s (2013) survey, on the other hand, has been used once (at the time of this publication), thus far, and, as such, does not have high levels of reliability. Notwithstanding, Halupa, in a personal communication, explained that the exploratory nature of the study and her attempt to assess various constructs resulted in a less than desirable Cronbach's alpha. Because I combined McCabe’s (2003) questionnaire with Halupa and Bolliger’s (2013) selfplagiarism survey and, as such, modified the structure and wording of the original instruments, reliability and validity were reestablished.

Reliability refers to the stability and consistency of an instrument. As the original questionnaires were modified and lengthened, I used coefficient alpha to examine the instrument's reliability. More specifically, Cronbach's alpha, a commonly used measure of internal consistency, assesses levels of intercorrelation among items in an index. It is not limited to dichotomous variables and, therefore, has greater use and applicability than Kuder-Richardson 20 (Ary et al., 2010). The intercorrelation among the four items forming an index for understanding self-plagiarism, the four items measuring faculty understanding of academic integrity policies, and the three item-index measuring faculty 
perceptions of institutional support yielded high coefficient alphas of $0.855,0.708$, and 0.903, respectively. High levels of intercorrelation suggests that the items are "presumed to measure the same thing” (Vogt, 2005, p. 7).

Validity questions whether the instrument actually measures what it purports to measure (Babbie, 1990; Kumar, 2014). Content validity, in particular, can be established via "justification of each question in relation to the objectives of the study" (Kumar, 2014, p. 213) or through the use of a panel of experts (Creswell, 2003; Ary et al., 2010; Kumar, 2014). To increase content validity, I developed a content matrix to demonstrate the link between the research objectives and survey questions (see Appendix D). Additionally, I forwarded the survey questionnaire to a panel of ten scholars who have published multiple articles, chapters, or books on academic integrity or dishonesty. Panel members were asked to comment upon instruction comprehension, ease of survey completion, question comprehension, the quality and quantity of response categories, and question sequencing. Four of the scholars provided feedback that was used to make one round of necessary revisions which ensured that the survey effectively and efficiently “test[s] the research question[s] validly and reliably” (Bourque \& Fielder, 2003, p. 93).

\section{Data Management}

Neither IP addresses nor e-mail addresses were recorded. I stored the data from the completed surveys electronically within a password protected folder that is stored on a password protected computer. A hard copy of the data was stored in a locked filing cabinet in a locked office. The dataset will be kept for a period of 3 years, after which it will be destroyed. 


\section{Variables}

\section{Dependent Variables}

I examined the following dependent concepts using Likert scales: student engagement in prohibited behaviors, perceptions of the academic environment (i.e., academic integrity policies and institutional support), and understanding of selfplagiarism. To assess student engagement in prohibited behaviors, the survey asked faculty to identify the frequency of student engagement in specific enumerated behaviors $(1=$ never, 2 = seldom, $3=$ often, $4=$ very often $)$. The following items were used to operationalize frequency of student engagement in selected behaviors:

1. Frequency with which students plagiarize written assignments

2. Frequency with which students inappropriately share work in group assignments

3. Frequency with which students cheat during tests/exams

4. Frequency with which students violate academic integrity policies.

Then, understanding and perceptions of institutional policies were operationalized using the following variables:

1. Faculty understanding of institutional policies

2. Faculty support of institutional policies

3. Severity of institutional policies

4. Policy effectiveness.

Perceptions of institutional responses to faculty attempts to thwart student engagement in academically dishonest behaviors comprised the third dependent concept. Items used to operationalize perceptions of institutional responses included: 
1. Faculty support and encouragement from department chairs

2. Faculty support and encouragement from deans

3. Faculty support and encouragement from senior administrators.

Last, the participants rated their understanding and perceptions of self-plagiarism $(1=$ Strongly Disagree, 2 = Disagree, 3 = Agree, 4 = Strongly Agree). The items used to operationalize understanding of self-plagiarism included:

1. Whether faculty believed that students who reused a part of a previous paper for a new assignment without citing the previous paper were self-plagiarizing

2. Whether faculty believed that students who reused assignments that were completed by a group of students in a course were self-plagiarizing

3. Whether faculty believed that students who reused (i.e., recycled) a completed paper for a new assignment were self-plagiarizing

4. Whether faculty believed that students who did not get the instructor's permission when they recycled their work in the participants’ courses were self-plagiarizing.

\section{Independent Variables}

I also examined the following independent variables in my analysis: academic rank, level of students primarily taught, setting in which most courses were taught, and gender. First, the survey asked faculty participants to identify their academic rank (1 = full professor, 2 = associate professor, 3 = assistant professor, $4=$ senior instructor, $5=$ instructor, 6 = lab coordinator/other). Next, the participants were asked to identify the academic level of students primarily taught $(1=$ freshmen and/or sophomores, $2=$ juniors and/or seniors, 3 = graduate students) as well as the academic setting within which the majority of their courses were taught ( 1 = on campus/face-to-face, 2 = hybrid/blended, 
and $3=$ online $)$. Finally, the participants were asked to identify their gender $(1=$ male, 2 = female).

In conclusion, the survey asked participants a series of questions regarding demographics, perceptions concerning the frequency of academically dishonest behaviors, perceptions of institutional policies, levels of institutional support, and their understanding of self-plagiarism.

\section{Data Analysis}

SPSS statistical software was used to analyze the data; the level of significance was set, a priori, at .05. First, I generated frequency distributions to show demographic characteristics of the participants. Next, I tested the bivariate relationships between each

of the independent variables (academic rank, academic level of students primarily taught, academic setting within the majority of courses were taught, and gender) and the dependent variables (the perceptions concerning the frequency of student engagement in academically dishonest behaviors, perceptions of academic integrity policies, perceptions of institutional support, and understanding of self-plagiarism) for statistical significance. Then, I used hierarchical log linear analyses to assess the associations between the variables measuring perceptions of academic integrity policies, perceptions of institutional support, and understanding of self-plagiarism as well as the tests of Partial Associations to determine which of the interactions were statistically significant.

\section{Summary}

In this chapter, I described the research design, sampling methods, and research procedures used in the study. I chose the electronic mail survey design to assess faculty understanding and perceptions of academic dishonesty. It was an appropriate selection 
based upon my need to draw inferences from samples to populations, the relative ease of use, and the low cost.

My target population consisted of university faculty employed within the Florida State University System. Four of the institutions ignored my public records requests, and two refused to participate. Therefore, I invited the faculty employed at the remaining six institutions to complete the survey. After securing a list of full-time instructional staff from those institutions, I generated a randomized list of faculty from whom I solicited assistance. I supplied the informed consent document to the individuals who elected to complete the survey, thus, informing them of the required time commitment, voluntariness of their participation, benefits of participation, and efforts made to protect their identities.

To assess faculty perceptions, I merged McCabe’s Faculty Academic Integrity Survey (2003) and Halupa and Bolliger’s Faculty Perceptions of Self-Plagiarism Survey (2013) to form a new instrument and, accordingly, reestablished reliability and validity. Afterwards, I presented a list of independent and dependent variables to be analyzed as well as plans for the statistical analysis which included, but were not limited to, univariate frequency distributions, bivariate analyses of the relationships between each of the independent and dependent variables, and hierarchical log linear analyses of the variables constituting the relevant dependent concepts. 


\title{
CHAPTER IV
}

\begin{abstract}
ANALYSIS
This chapter provides a detailed analysis of the data. Descriptive univariate statistics are presented to show demographic characteristics of the faculty and their perceptions of academic misconduct. Bivariate relationships between each of the independent variables and the dependent variables are analyzed to identify which factors are related to faculty perceptions of student engagement in academically dishonest behaviors, academic integrity policies, institutional support, and self-plagiarism. Finally, multiway frequency analyses are used to assess the associations between the variables constituting relevant dependent concepts.

The study was guided by the following research questions:

1. How do university faculty perceive their institutions' academic integrity policies?

2. How do university faculty perceive their institutions' responses to policy violations?
\end{abstract}

3. How do faculty understand self-plagiarism?

Several subordinate questions were also of importance:

1. Do the perceptions of university faculty vary by academic rank?

2. Do the perceptions of university faculty vary across course setting?

3. Do the perceptions of university faculty vary in accordance with the academic level of students taught?

4. Do the perceptions of university faculty vary by gender? 


\section{Description of the Sample}

Table 2 presents the descriptive statistics for the sample. As the table showed, the Carnegie Classifications of Institutions of Higher Education varied considerably. Fortytwo percent of the faculty-respondents were employed by institutions of higher education (IHEs) classified as Doctoral/Research universities. Twenty-five percent of facultyrespondents were employed by doctorate-granting universities designated as high or very high research activity, 28.9\% were employed by institutions designated as Master’s Colleges and Universities, and the remaining $4 \%$ were employed by Baccalaureate Colleges. In terms of the respondents' academic rankings, approximately $70 \%$ held the positions of assistant, associate, or full professor $(19.4 \%, 24.9 \%$, and $25.4 \%$, respectively); 30\% were instructors or lecturers, and the remaining faculty were employed as lab coordinators or held other teaching positions. Sixteen percent of the faculty had limited experiences teaching within higher education (1-5 years) while 18\% had 6-10 years of experience. Approximately 30\% of faculty possessed 11-20 years of collegiate-level experience (15\% reported 11-15 years of experience, and 15\% reported 16-20 years of experience); nearly 35\% reported more than 20 years of experience in higher education. The instructors' primary area of teaching responsibilities also varied considerably. More than one-fourth of the respondents taught within the social sciences (26.9\%); almost one-third taught within the STEM fields (3\% taught engineering, 17\% math or science, and $9 \%$ taught within nursing/health professions). Fourteen percent of the faculty reported teaching interdisciplinary courses while approximately $11 \%$ (respectively) taught either business or humanities courses. The remaining 9\% were divided between the arts (4.5\%) and communications/journalism (4\%). 
Nearly $17 \%$ of faculty-respondents reported teaching lower level undergraduates (freshmen and sophomores) while $55.2 \%$ of faculty taught upper level undergraduates (juniors and seniors), and 27.9\% taught graduate students. Seventy-seven percent of respondents reported teaching on campus, while 22\% reported either teaching hybrid/blended or fully online courses (11.9\% and $10.9 \%$, respectively). Fifteen percent of faculty-respondents asserted that their largest courses had an enrollment of 1-25 students; however, a considerable number of faculty (46.3\%) reported courses with an enrollment of 26-49 students. Nineteen percent of respondents taught courses with 50-74 students, and 19.4\% taught courses with enrollments of 75 or more students. Forty-seven percent of the faculty-respondents were men and 53\% were women. 
Table 2

Univariate Analyses for Faculty Demographics $(N=201)$.

\begin{tabular}{lrr}
\hline Variable & Frequency & Percent \\
\hline Carnegie Classification & & \\
Doctoral/Research University & 85 & 42.3 \\
High/Very High Research University & 51 & 25.4 \\
Master's College and University & 58 & 28.9 \\
Baccalaureate College & 7 & 3.5 \\
& & \\
Academic Rank & & \\
Assistant Professor & 39 & 19.4 \\
Associate Professor & 50 & 24.9 \\
Full Professor & 51 & 25.4 \\
Instructor/Lecturer & 60 & 29.9 \\
Lab Coordinator/Other & 1 & 0.5
\end{tabular}

Length of Time Teaching in Higher Ed

$1-5$ years

6-10 years

11-15 years

16-20 years

14.9

Over 20 years

Primary Area of Teaching Responsibility

Arts

Business

Communications/Journalism

Engineering

Humanities

Math or Science

Nursing/Health Professions

Social Sciences

Interdisciplinary

13.9

Level of Students Primarily Taught

Lower-level undergraduates

16.9

Upper-level undergraduates

Graduate Students 
Table 2

Univariate Analyses for Faculty Demographics ( $N=201)$ (continued).

\begin{tabular}{lrr}
\hline Variable & Frequency & Percent \\
\hline Course Setting & & \\
On campus/face-to-face & 155 & 77.1 \\
Hybrid/blended & 24 & 11.9 \\
Online & 22 & 10.9 \\
& & \\
Class Size & & \\
$1-25$ students & 30 & 14.9 \\
$26-49$ students & 93 & 46.3 \\
50-74 students & 39 & 19.4 \\
$75-99$ students & 11 & 5.5 \\
100 or more students & 28 & 13.9 \\
& & \\
Gender & & 47.3 \\
Male & 95 & 52.7 \\
Female & 106 & \\
\hline
\end{tabular}

\section{Perceptions of Student Behaviors}

Next, faculty rated their perceptions of student engagement in academically dishonest behaviors. Table 3 shows their perceptions about the frequency with which students engaged in certain behaviors. The majority of the faculty (57.3\%) believed that undergraduate students commonly plagiarize written assignments, and 67.6\% believed that undergraduate students inappropriately share work in group assignments with regularity. Nearly one-third (32.4\%) of faculty-respondents asserted that undergraduate students regularly cheat on exams while $46.3 \%$ of faculty believed that undergraduate students regularly violate academic integrity policies.

Respondents answered the same questions about the behaviors of graduate students. The vast majority of faculty-respondents believed that graduate students rarely, 
if ever, engage in academic misconduct. More specifically, $86.1 \%$ believed graduate students never or rarely plagiarize assignments. Approximately 93\% of faculty asserted that graduate students never or rarely cheat on exams, and $77.1 \%$ of respondents believed that graduate students frequently comply with faculty members' directives prohibiting the sharing of work in group assignments. Last, $89.1 \%$ of faculty asserted that graduate students never or rarely violate academic integrity policies.

Table 3

Univariate Statistics for Undergraduate and Graduate Student Engagement in Academic Misconduct $(N=201)$.

\begin{tabular}{|c|c|c|c|c|}
\hline Variable & $\begin{array}{r}\text { Never } \\
(\%)\end{array}$ & $\begin{array}{r}\text { Seldom } \\
(\%)\end{array}$ & $\begin{array}{r}\text { Often } \\
(\%)\end{array}$ & $\begin{array}{r}\begin{array}{r}\text { Very Often } \\
(\%)\end{array} \\
\end{array}$ \\
\hline \multicolumn{5}{|l|}{ Undergraduates misconduct } \\
\hline Plagiarizing written assignments & $\begin{array}{r}2 \\
(1.0)\end{array}$ & $\begin{array}{r}84 \\
(41.8)\end{array}$ & $\begin{array}{r}95 \\
(47.3)\end{array}$ & $\begin{array}{r}20 \\
(10.0)\end{array}$ \\
\hline Wrongfully sharing group assignments & $\begin{array}{r}2 \\
(1.0)\end{array}$ & $\begin{array}{r}63 \\
(31.3)\end{array}$ & $\begin{array}{r}102 \\
(50.7)\end{array}$ & $\begin{array}{r}34 \\
(16.9)\end{array}$ \\
\hline Cheating during tests/exams & $\begin{array}{r}5 \\
(2.5)\end{array}$ & $\begin{array}{r}131 \\
(65.2)\end{array}$ & $\begin{array}{r}57 \\
(28.4)\end{array}$ & $\begin{array}{r}8 \\
(4.0)\end{array}$ \\
\hline Violating academic integrity policies & $\begin{array}{r}3 \\
(1.5)\end{array}$ & $\begin{array}{r}105 \\
(52.2)\end{array}$ & $\begin{array}{r}82 \\
(40.8)\end{array}$ & $\begin{array}{r}11 \\
(5.5)\end{array}$ \\
\hline \multicolumn{5}{|l|}{ Graduates misconduct } \\
\hline Plagiarizing written assignments & $\begin{array}{r}13 \\
(6.5)\end{array}$ & $\begin{array}{r}160 \\
(79.6)\end{array}$ & $\begin{array}{r}23 \\
(11.4)\end{array}$ & $\begin{array}{r}5 \\
(2.5)\end{array}$ \\
\hline Wrongfully sharing group assignments & $\begin{array}{r}13 \\
(6.5)\end{array}$ & $\begin{array}{r}142 \\
(70.6)\end{array}$ & $\begin{array}{r}36 \\
(17.9)\end{array}$ & $\begin{array}{r}10 \\
(5.0)\end{array}$ \\
\hline Cheating during tests/exams & $\begin{array}{r}33 \\
(16.4)\end{array}$ & $\begin{array}{r}153 \\
(76.1)\end{array}$ & $\begin{array}{r}12 \\
(6.0)\end{array}$ & $\begin{array}{r}3 \\
(1.5)\end{array}$ \\
\hline Violating academic integrity principles & $\begin{array}{r}12 \\
(6.0) \\
\end{array}$ & $\begin{array}{r}167 \\
(83.1) \\
\end{array}$ & $\begin{array}{r}20 \\
(10.0) \\
\end{array}$ & $\begin{array}{r}2 \\
(1.0) \\
\end{array}$ \\
\hline
\end{tabular}




\section{Perceptions of the Seriousness of Academic Offenses}

The faculty also rated the severity of specific academic offenses. Table 4 summarizes their perceptions. Faculty perceived the following behaviors as particularly egregious with upwards of $80 \%$ of faculty rating the infractions as serious cheating: copying material, almost word for word, from any written source and turning it in as one’s own; copying the homework assignment of another student; copying from another student during an exam with that student's knowledge; copying from another student during an exam without that student's knowledge; using digital technology to get unpermitted assistance during an exam; fabricating or falsifying labs; fabricating or falsifying research; helping others cheat on exams; turning in a paper obtained from a paper mill and claiming it as one’s own; purchasing a paper from a website and claiming it as one's own; and turning in the work of another student. However, the respondents did not perceive fabricating or falsifying a bibliography; using a false excuse to obtain an extension for an assignment or exam; paraphrasing or copying a few sentences from books, magazines, or journals without proper citation; receiving unpermitted help on an assignment; turning in a paper that was already submitted to another faculty member for a grade; and working with others when the professor had asked for individual work as serious academic infractions. In fact, approximately $15 \%$ of respondents rated fabricating or falsifying a bibliography, receiving unpermitted help on an assignment, or turning in a paper that had already been submitted to another faculty member for evaluation as either not cheating or trivial cheating (14.4\%, 15.4\% and 13.4\%, respectively) while nearly one-fourth of faculty rated paraphrasing (or copying) a few 
sentences from a written text without proper citation or working with others when the professor had asked for individual work as not cheating or trivial (22.4\%, each).

Table 4

Univariate Statistics for Perceptions of Seriousness of Academic Offense $(N=201)$.

\begin{tabular}{|c|c|c|}
\hline Variable & Frequency & Percent \\
\hline \multicolumn{3}{|c|}{$\begin{array}{l}\text { Copying material, word for word, and turning it } \\
\text { in as one's own }\end{array}$} \\
\hline Not Cheating/Trivial Cheating & 4 & 2.0 \\
\hline Moderate Cheating & 24 & 11.9 \\
\hline Serious Cheating & 173 & 86.1 \\
\hline \multicolumn{3}{|c|}{ Copying another student's homework assignment } \\
\hline Not Cheating/Trivial Cheating & 5 & 2.5 \\
\hline Moderate Cheating & 24 & 11.9 \\
\hline Serious Cheating & 172 & 85.6 \\
\hline \multicolumn{3}{|c|}{$\begin{array}{l}\text { Copying from another student during a test with } \\
\text { that student's knowledge }\end{array}$} \\
\hline Not Cheating/Trivial Cheating & 6 & 3.0 \\
\hline Moderate Cheating & 12 & 6.0 \\
\hline Serious Cheating & 183 & 91.0 \\
\hline \multicolumn{3}{|c|}{$\begin{array}{l}\text { Copying from another student during a test } \\
\text { without that student's knowledge }\end{array}$} \\
\hline Not Cheating/Trivial Cheating & 5 & 2.5 \\
\hline Moderate Cheating & 16 & 8.0 \\
\hline Serious Cheating & 180 & 89.6 \\
\hline
\end{tabular}

Using digital technology to get unpermitted help

during a test

Not Cheating/Trivial Cheating

4.5

Moderate Cheating 24

11.9

Serious Cheating

168

83.6

Using electronics/digital devices as unauthorized

help during a test

$\begin{array}{lll}\text { Not Cheating/Trivial Cheating } & 6 & 3.0\end{array}$

$\begin{array}{lll}\text { Moderate Cheating } & 36 & 17.9\end{array}$

$\begin{array}{lll}\text { Serious Cheating } & 159 & 79.1\end{array}$ 
Table 4

Univariate Statistics for Perceptions of Seriousness of Academic Offense $(N=201)$ (continued).

\begin{tabular}{lrr}
\hline Variable & Frequency & Percent \\
\hline $\begin{array}{l}\text { Getting the questions/answer from someone who } \\
\text { already took the test }\end{array}$ & & \\
Not Cheating/Trivial Cheating & 14 & 7.0 \\
Moderate Cheating & 45 & 22.4 \\
Serious Cheating & 142 & 70.6
\end{tabular}

Helping another student cheat on a test

Not Cheating/Trivial Cheating 5

$5 \quad 2.5$

$\begin{array}{lrr}\text { Moderate Cheating } & 29 & 14.4\end{array}$

$\begin{array}{lll}\text { Serious Cheating } & 167 & 83.1\end{array}$

Turning in a paper obtained from a paper mill

and claiming it as one's own

$\begin{array}{lrr}\text { Not Cheating/Trivial Cheating } & 5 & 2.5\end{array}$

$\begin{array}{lll}\text { Moderate Cheating } & 8 & 4.0\end{array}$

$\begin{array}{lll}\text { Serious Cheating } & 185 & 93.5\end{array}$

Turning in a paper purchased from a website

and claiming it as one's own

$\begin{array}{lll}\text { Not Cheating/Trivial Cheating } & 5 & 2.5\end{array}$

$\begin{array}{lll}\text { Moderate Cheating } & 7 & 3.5\end{array}$

$\begin{array}{lll}\text { Serious Cheating } & 189 & 94.0\end{array}$

Receiving unpermitted help on an assignment

$\begin{array}{lrr}\text { Not Cheating/Trivial Cheating } & 31 & 15.4\end{array}$

$\begin{array}{lll}\text { Moderate Cheating } & 100 & 49.8\end{array}$

$\begin{array}{lll}\text { Serious Cheating } & 70 & 34.8\end{array}$

Turning in a paper already submitted to another

instructor for evaluation

$\begin{array}{lll}\text { Not Cheating/Trivial Cheating } & 27 & 13.4\end{array}$

Moderate Cheating $\quad 63 \quad 31.3$

Serious Cheating $\quad 111 \quad 55.2$ 
Table 4

Univariate Statistics for Perceptions of Seriousness of Academic Offense $(N=201)$ (continued).

\begin{tabular}{lrr} 
Variable & Frequency & Percent \\
\hline $\begin{array}{l}\text { Turning in the work of another student and } \\
\text { claiming it as one's own }\end{array}$ & & \\
Not Cheating/Trivial Cheating & 6 & 3.0 \\
Moderate Cheating & 11 & 5.5 \\
Serious Cheating & 184 & 91.5
\end{tabular}

Working with others when the instructor asked

for individual work

Not Cheating/Trivial Cheating 45

$45 \quad 22.4$

Moderate Cheating $\quad 105 \quad 52.2$

$\begin{array}{lll}\text { Serious Cheating } & 51 & 25.4\end{array}$

Fabricating or falsifying a bibliography

$\begin{array}{lll}\text { Not Cheating/Trivial Cheating } & 29 & 14.4\end{array}$

$\begin{array}{lll}\text { Moderate Cheating } & 91 & 45.3\end{array}$

$\begin{array}{lll}\text { Serious Cheating } & 81 & 40.3\end{array}$

Fabricating or falsifying labs

$\begin{array}{lll}\text { Not Cheating/Trivial Cheating } & 6 & 3.0\end{array}$

$\begin{array}{lrr}\text { Moderate Cheating } & 18 & 9.0\end{array}$

$\begin{array}{lll}\text { Serious Cheating } & 177 & 88.1\end{array}$

Fabricating or falsifying research

$\begin{array}{lll}\text { Not Cheating/Trivial Cheating } & 7 & 3.5\end{array}$

Moderate Cheating $\quad 9 \quad 4.5$

$\begin{array}{lrr}\text { Serious Cheating } & 185 & 92.0\end{array}$

Providing a false excuse to get an extension for an assignment or test

$\begin{array}{lll}\text { Not Cheating/Trivial Cheating } & 30 & 14.9\end{array}$

$\begin{array}{lll}\text { Moderate Cheating } & 64 & 31.8\end{array}$

\begin{tabular}{lll} 
Serious Cheating & 107 & 53.2 \\
\hline
\end{tabular} 


\section{Perceptions and Understanding of Academic Integrity Policies}

Tables 5 and 6 present the descriptive statistics pertaining to faculty knowledge of institutional policies prohibiting academic dishonesty. First, the faculty identified the sources from which they learned about their institutions’ academic integrity policies; they were permitted to select multiple sources. The majority of the faculty discovered information about policies from either the faculty handbook (59.7\%) or other faculty (56.2\%). Slightly less than half of the respondents reported hearing about the policies during faculty orientation (44.8\%) or from their department chairs (43.5\%). More than one-third of faculty reported learning about institutional policies from the university catalog (38.3\%) or the campus website (38.5\%). Twenty-five percent learned about the policies from deans or other administrators. Less than $10 \%$ of respondents reported discovering information about the policies from students or from the publicized outcomes of judicial hearings ( $7.5 \%$ and 5\%, respectively). Finally, 3\% of the faculty asserted that they were never informed of institutional policies.

Next, faculty rated the severity of penalties for violating their institutions' academic integrity policies. Nearly $83 \%$ of the faculty-respondents indicated that the severity of penalties for cheating at their institution as moderate or high (55.7\% and $26.4 \%$, respectively) while the remaining $17.9 \%$ asserted minimal penalties. The majority of the respondents rated the faculty's understanding of the academic integrity policies as moderate (56.2\%) while $11.4 \%$ and $32.3 \%$ assessed faculty understanding of policies as low and high, respectively. Approximately $12 \%$ of the respondents rated faculty support of these policies as low, $45 \%$ rated faculty support as moderate, and the remaining $43 \%$ rated faculty support as high. Last, the majority of faculty rated policy 
effectiveness as moderate or high (59.2\% and 13.4\%, respectively), while the remaining 27.4\% rated effectiveness as low.

Eighty-seven percent of faculty-respondents reported the existence of an institutional procedure to deal with student engagement in academically dishonest behaviors. Of those faculty reporting established procedures, $67.8 \%$ indicated that the policies were clear and easy to follow whereas $32.2 \%$ indicated that the policies were not.

Table 5

Univariate Statistics for Sources of Information for Academic Integrity Policies $(N=201)$.

\begin{tabular}{lrrr}
\hline Variable & Frequency & $\begin{array}{r}\text { Percent of } \\
\text { Responses }\end{array}$ & $\begin{array}{r}\text { Percent of } \\
\text { Cases }\end{array}$ \\
\hline Sources of Information & & & 44.8 \\
Faculty Orientation & 120 & 18.6 & 59.7 \\
Faculty Handbook & 87 & 13.5 & 43.3 \\
Department Chair & 113 & 17.5 & 56.2 \\
Other Faculty & 50 & 7.8 & 24.9 \\
Deans or Administrators & 15 & 2.3 & 7.5 \\
Students & 77 & 11.9 & 38.3 \\
University Catalog & 10 & 1.6 & 5.0 \\
Publicized Outcome of Hearings & 77 & 11.9 & 38.3 \\
Campus Website & 6 & 0.9 & 3.0 \\
Never Informed & 645 & $100 \%$ & \\
\hline Total & & & \\
\hline
\end{tabular}


Table 6

Univariate Statistics for Perceptions and Understanding Academic Integrity Policies $(N=201)$.

\begin{tabular}{lrr}
\hline Variable & Frequency & Percent \\
\hline Severity of penalties for cheating & & \\
Low & 36 & 17.9 \\
Moderate & 112 & 55.7 \\
High & 53 & 26.4
\end{tabular}

Faculty understanding of policies

Low

Moderate

113

56.2

High

65

32.3

Faculty support of policies

Low

Moderate

High

Policy effectiveness

Low

Moderate

High

Established institutional procedure

Yes

No

I don't know

22

10.9

Procedure clear and easy to follow

Yes

$\begin{array}{rr}118 & 67.8 \\ 56 & 32.2\end{array}$

\section{Perceptions of Institutional Support}

Table 7 summarizes respondents’ perceptions of institutional support in identifying and handling student engagement in academically dishonest behaviors. Faculty-respondents indicated (agree or strongly agree) that the department chairs, deans, 
and administrators, for the most part, were supportive and encouraged faculty to report instances of academic dishonesty (80.6\%, 78.6\%, and 74.1\%, respectively). Notwithstanding, $19.8 \%$ of department chairs, $21.4 \%$ of deans, and $25.9 \%$ of administrators were perceived as being neither supportive nor encouraging in the quest to combat academically dishonest behaviors.

Faculty answered questions regarding whether or not they had ever referred a student accused of academic misconduct to the appropriate administrator. More than half of the faculty (53.2\%) had referred students to administrators. Of those who referred students, $27.1 \%$ were either unsatisfied or very unsatisfied (15\% and $12.1 \%$, respectively) with the administrator's response. Forty-five percent were satisfied with the way the case(s) were handled and $28 \%$ were very satisfied. Nearly $80 \%$ of all of the facultyrespondents asserted that, if the situation so warranted, they would report future incidents of academic integrity policy violations. 
Table 7

Univariate Statistics for Perceptions of Institutional Support $(N=201)$.

\begin{tabular}{|c|c|c|}
\hline Variable & Frequency & Percent \\
\hline \multicolumn{3}{|c|}{ Dept. chairs are supportive and encouraging } \\
\hline Strongly disagree & 2 & 1 \\
\hline Disagree & 37 & 18.4 \\
\hline Agree & 107 & 53.2 \\
\hline Strongly agree & 55 & 27.4 \\
\hline \multicolumn{3}{|c|}{ Deans are supportive and encouraging } \\
\hline Strongly disagree & 5 & 2.5 \\
\hline Disagree & 38 & 18.9 \\
\hline Agree & 105 & 52.2 \\
\hline Strongly agree & 53 & 26.4 \\
\hline \multicolumn{3}{|c|}{ Administrators are supportive and encouraging } \\
\hline Strongly disagree & 12 & 6 \\
\hline Disagree & 40 & 19.9 \\
\hline Agree & 105 & 52.2 \\
\hline Strongly agree & 44 & 21.9 \\
\hline \multicolumn{3}{|c|}{ Faculty referred student to administration } \\
\hline Yes & 107 & 53.2 \\
\hline No & 94 & 46.8 \\
\hline \multicolumn{3}{|c|}{ Level of satisfaction with institutional response } \\
\hline Very unsatisfied & 13 & 12.1 \\
\hline Unsatisfied & 16 & 15.0 \\
\hline Satisfied & 48 & 44.9 \\
\hline Very satisfied & 30 & 28.0 \\
\hline \multicolumn{3}{|c|}{ Faculty will report in future } \\
\hline Yes & 159 & 79.1 \\
\hline No & 5 & 2.5 \\
\hline I don’t know & 37 & 18.4 \\
\hline
\end{tabular}




\section{Understanding of Self-Plagiarism}

In the next section, faculty-respondents indicated their level of agreement that certain behaviors constituted self-plagiarism as well as with faculty roles and responsibilities. Table 8 presents the results. The majority of faculty (75.1\%) did not believe that self-plagiarism was clearly defined. Seventy-one percent of respondents asserted that faculty did not understand self-plagiarism, yet nearly $87 \%$ of them believed that faculty bore the responsibility of teaching students about appropriate behaviors regarding self-plagiarism. Nevertheless, only $18 \%$ of faculty assumed that students had been educated about acceptable practices.

Faculty perceptions of the relationship between student learning and selfplagiarism warranted attention. To begin, $28.9 \%$ of respondents believed that faculty should encourage students to reuse parts of their previously submitted papers for written assignments. Ninety-three percent of faculty asserted that students who built on previous assignments could increase their depth of learning, and $73.7 \%$ believed that students who incorporated previous assignments into new assignments in appropriate ways were using their time wisely. On the other hand, approximately $68 \%$ of faculty claimed that students who reused part of previously written papers for new assignments could expect potential problems. The vast majority of faculty asserted that students who reused a part of a previous paper for a new assignment without citing the previous paper, who reused assignments that were completed by a group of students in a course, or who reused a completed paper for a new assignment were self-plagiarizing (76.1\%, 82.1\%, and 86.5\%, respectively). Last, nearly $80 \%$ of faculty agreed that the failure to secure the instructor's permission when recycling their work constituted self-plagiarism. 
Table 8

Univariate Statistics for Understanding Self-Plagiarism, Faculty Roles and Responsibilities, and Student Learning $(N=201)$.

\begin{tabular}{|c|c|c|c|c|}
\hline Variable & $\begin{array}{r}\text { Strongly } \\
\text { Disagree } \\
N(\%)\end{array}$ & $\begin{array}{r}\text { Disagree } \\
N(\%)\end{array}$ & $\begin{array}{l}\text { Agree } \\
N(\%)\end{array}$ & $\begin{array}{r}\text { Strongly } \\
\text { Agree } \\
N(\%)\end{array}$ \\
\hline \multicolumn{5}{|l|}{ Understanding self-plagiarism } \\
\hline Self-plagiarism is clearly defined & $37(18.4)$ & $114(56.7)$ & $38(18.9)$ & $12(6.0)$ \\
\hline Self-plagiarism is clearly understood by faculty & $33(16.4)$ & $110(54.7)$ & $49(24.4)$ & $9(4.5)$ \\
\hline \multicolumn{5}{|l|}{ Faculty roles and responsibilities } \\
\hline $\begin{array}{l}\text { Faculty should teach students about appropriate behaviors regarding } \\
\text { self-plagiarism }\end{array}$ & $3(1.5)$ & $24(11.9)$ & $126(62.7)$ & $48(23.7)$ \\
\hline $\begin{array}{l}\text { Faculty should assume students have been educated about } \\
\text { acceptable practices }\end{array}$ & $45(22.4)$ & $119(59.2)$ & $25(12.4)$ & $12(6.0)$ \\
\hline Faculty should assume students do not engage in self-plagiarism & $56(27.5)$ & $114(56.7)$ & $26(12.9)$ & $5(2.5)$ \\
\hline $\begin{array}{l}\text { Faculty should encourage students to reuse parts of their previously } \\
\text { submitted papers for new assignments }\end{array}$ & $44(21.9)$ & $99(49.3)$ & $49(24.4)$ & $9(4.5)$ \\
\hline Student learning & & & & \\
\hline $\begin{array}{l}\text { Students who build on previous assignments can increase their depth } \\
\text { of learning }\end{array}$ & $2(1.0)$ & $12(6.0)$ & $152(75.6)$ & $35(17.4)$ \\
\hline $\begin{array}{l}\text { Students who incorporate previous assignments in new assignments } \\
\text { in appropriate ways use their time wisely }\end{array}$ & $4(2.0)$ & $49(24.4)$ & $128(63.7)$ & $20(10.0)$ \\
\hline Students who reuse part of previously written papers for new & $3(1.5)$ & $62(30.8)$ & $119(59.2)$ & $17(8.5)$ \\
\hline
\end{tabular}


Table 8

Univariate Statistics for Understanding Self-Plagiarism, Faculty Roles and Responsibilities, and Student Learning $(N=201)$ (continued).

\begin{tabular}{|c|c|c|c|c|}
\hline Variable & $\begin{array}{r}\text { Strongly } \\
\text { Disagree } \\
N(\%)\end{array}$ & $\begin{array}{r}\text { Disagree } \\
N(\%)\end{array}$ & $\begin{array}{l}\text { Agree } \\
N(\%)\end{array}$ & $\begin{array}{r}\text { Strongly } \\
\text { Agree } \\
N(\%)\end{array}$ \\
\hline $\begin{array}{l}\text { Students who reuse a part of a previous paper for a new assignment } \\
\text { without citing the previous paper are self-plagiarizing }\end{array}$ & $4(2.0)$ & 44 (21.9) & 117 (58.2) & 36 (17.9) \\
\hline $\begin{array}{l}\text { Students who reuse assignments that were completed by a group of } \\
\text { students in a course are self-plagiarizing }\end{array}$ & $2(1.0)$ & 34 (16.9) & 120 (59.7) & 45 (22.4) \\
\hline $\begin{array}{l}\text { Students who reuse a completed paper for a new assignment are self- } \\
\text { plagiarizing }\end{array}$ & & & & \\
\hline $\begin{array}{l}\text { Students who do NOT get permission when they recycle their work in } \\
\text { my courses are self-plagiarizing }\end{array}$ & $2(1.0)$ & 25 (12.4) & 104 (51.7) & $70(34.8)$ \\
\hline $\begin{array}{l}\text { Students do NOT need to cite themselves if they use an excerpt they } \\
\text { wrote for a previous paper to prevent self-plagiarism }\end{array}$ & $41(20.4)$ & 38 (18.9) & 98 (48.8) & $61(30.3)$ \\
\hline
\end{tabular}




\section{Bivariate Analyses}

I tested the bivariate relationships between each of the independent and dependent variables for statistical significance using Pearson’s chi-square. To facilitate understanding of statistically significant relationships and to reduce the proportion of cells with less than five cases, I recoded the variables of interest, as necessary, to reflect dichotomous relationships.

\section{Perceptions of Academic Misconduct Among Students}

Pearson's chi-square was used to ascertain if there were any significant associations between faculty perceptions of student engagment in academically dishonest behaviors and the independent variables. The results are presented in Tables 9 through 16. The analysis revealed that only one independent variable, gender, varied with perceptions of undergraduate student behaviors. Female faculty were significantly more likely than male faculty to believe that undergraduate students plagiarize on written assignments (66\% and 47.4\%, respectively), $\chi^{2}(1, N=201)=7.133, p<.01$, and to believe (44.3\% and $18.9 \%$, respectively) that undergraduate students regularly cheat on exams, $\left.\chi^{2}(1, N=201)=14.763, p<.01\right)$. Women were also more likely than men to believe that undergraduate students wrongfully share their work (74.5\% and 60\%, respectively), $\chi^{2}(1, N=201)=4.833, p<.05$, and violate institutional integrity policies $\left(55.7 \%\right.$ and $35.8 \%$, respectively), $\left.\chi^{2}(1, N=201)=7.957, p<.01\right)$ with some degree of regularity. 
Table 9

Bivariate Results for Perceptions of Undergraduate Students Cheat by Faculty Rank, Course Setting, Level of Students Taught, and Gender $(N=201 ; d f=1)$.

\begin{tabular}{|c|c|c|c|c|}
\hline Variable & $\begin{array}{r}\text { Undergraduate } \\
\text { Students Cheat on } \\
\text { Exams } \\
\end{array}$ & $\begin{array}{l}\text { Undergraduate } \\
\text { Students Do Not } \\
\text { Cheat on Exams }\end{array}$ & $\chi^{2}$ & $p$ \\
\hline & $N(\%)$ & $N(\%)$ & & \\
\hline Faculty Rank & & & 0.556 & 0.456 \\
\hline Tenured/Tenure-track & $43(30.7 \%)$ & 97 (69.3\%) & & \\
\hline Non-tenure track & $22(36.1 \%)$ & 39 (63.9\%) & & \\
\hline Course setting & & & 3.383 & 0.066 \\
\hline On campus & $45(29.0 \%)$ & $110(71.0 \%)$ & & \\
\hline Hybrid/Online & $20(43.5 \%)$ & $26(56.5 \%)$ & & \\
\hline Level of students & & & 1.712 & 0.191 \\
\hline Undergraduates & $43(29.7 \%)$ & $102(70.3 \%)$ & & \\
\hline Graduates & $22(39.3 \%)$ & $34(60.7 \%)$ & & \\
\hline Gender & & & 14.763 & $<0.001^{* *}$ \\
\hline Male & $18(18.9 \%)$ & 77 (81.1\%) & & \\
\hline Female & $47(44.3 \%)$ & $59(55.7 \%)$ & & \\
\hline
\end{tabular}

Notes: *Significant at .05 level

**Significant at .01 level 
Table 10

Bivariate Results for Perceptions of Undergraduate Students Plagiarize Written Assignments by Faculty Rank, Course Setting, Level of Students Taught, and Gender $(N=201 ; d f=1)$.

Variable Undergraduates $\quad$ Undergraduates Do $\quad \chi^{2} \quad p$ Plagiarize Not Plagiarize Assignments Assignments

$$
N(\%) \quad N(\%)
$$

Faculty Rank

Tenured/Tenure-track

$80(57.1 \%)$

$35(57.4 \%)$

$60(42.9 \%)$

Non-tenure track

26 (42.6\%)

Course setting

$83(53.5 \%)$

$3.717 \quad 0.054$

On campus

$32(69.6 \%)$

72 (46.5\%)

Hybrid/Online

$$
\text { (32) }
$$$$
14 \text { (30.4\%) }
$$

Level of students

$84(57.9 \%)$

Undergraduates

31 (55.4\%)

$61(42.1 \%)$

Graduates

\section{$31(55.4 \%)$}

25 (44.6\%)

Gender

$45(47.4 \%)$

70 (66.0\%)

50 (52.6\%)

Female

Notes: *Significant at .05 level

**Significant at .01 level

$0.001 \quad 0.975$
$0.109 \quad 0.741$
$0.109 \quad 0.741$

$7.1330 .008 * *$ 
Table 11

Bivariate Results for Perceptions of Undergraduate Students Wrongfully Share Work by Faculty Rank, Course Setting, Level of Students Taught, and Gender $(N=201, d f=1)$.

Variable

$\begin{array}{rccc}\begin{array}{r}\text { Undergraduates } \\ \text { Wrongfully Share } \\ \text { Work }\end{array} & \begin{array}{r}\text { Undergraduates Do } \\ \text { Not Share Work }\end{array} & \chi^{2} & p \\ N(\%) & N(\%) & \end{array}$

Faculty Rank

$1.494 \quad 0.222$

Tenured/Tenure-track

$91(65.0 \%)$

$49(35.0 \%)$

Non-tenure track

$45(73.8 \%)$

$16(26.2 \%)$

Course setting

On campus

$103(66.5 \%)$

$52(33.5 \%)$

$0.453 \quad 0.501$

Hybrid/Online

$33(71.7 \%)$

$13(28.3 \%)$

Level of students

97 (66.9\%)

$0.139 \quad 0.709$

Undergraduates

39 (69.6\%)

48 (33.1\%)

Graduates

(69.6\%)

17 (30.4\%)

Gender

57 (60.0\%)

$4.8330 .028^{*}$

Male

79 (74.5\%)

38 (40.0\%)

Female

Notes: *Significant at .05 level

**Significant at .01 level 27 (25.5\%) 
Table 12

Bivariate Results for Perceptions of Undergraduate Students Violate Integrity Policies by Faculty Rank, Course Setting, Level of Students Taught, and Gender $(N=201, d f=1)$.

\begin{tabular}{|c|c|c|c|c|}
\hline Variable & $\begin{array}{l}\text { Undergraduates } \\
\text { Violate Policies }\end{array}$ & $\begin{array}{r}\text { Undergraduates Do } \\
\text { Not Violate } \\
\text { Policies }\end{array}$ & $\chi^{2}$ & $p$ \\
\hline & $N(\%)$ & $N(\%)$ & & \\
\hline Faculty Rank & & & 0.730 & 0.393 \\
\hline Tenured/Tenure-track & $62(44.3 \%)$ & 78 (55.7\%) & & \\
\hline Non-tenure track & $31(50.8 \%)$ & $30(49.2 \%)$ & & \\
\hline \multicolumn{5}{|l|}{ Course setting } \\
\hline On campus & $70(45.2 \%)$ & 85 (54.8\%) & 0.334 & 0.563 \\
\hline Hybrid/Online & $23(50.0 \%)$ & $23(50.0 \%)$ & & \\
\hline Level of students & & & 0.118 & 0.731 \\
\hline Undergraduates & $66(45.5 \%)$ & 79 (54.5\%) & & \\
\hline Graduates & $27(48.2 \%)$ & $29(51.8 \%)$ & & \\
\hline Gender & & & 7.957 & $0.005^{* *}$ \\
\hline Male & $34(35.8 \%)$ & $61(64.2 \%)$ & & \\
\hline Female & $59(55.7 \%)$ & $47(44.3 \%)$ & & \\
\hline
\end{tabular}

Notes: *Significant at .05 level

**Significant at .01 level

I repeated the same analysis for faculty perceptions of graduate students’

involvement in academically dishonest behaviors. Chi-square analyses revealed that neither faculty rank nor academic level of students taught were associated with the frequency with which faculty believed that graduate students engaged in academically dishonest behaviors. Nevertheless, faculty perceptions varied in accordance with gender and course setting. More specifically, female faculty (12.3\%) were more likely than male faculty $(2.1 \%)$ to believe that graduate students regularly cheated on exams, $\chi^{2}(1, N=$ $201)=7.487, p<.01$, and violated institutional policies, $\chi^{2}(1, N=201)=3.961, p<.05$, (15.1\% of women and $6.3 \%$ of men). Additionally, online faculty (23.9\%) were more 
likely than campus-based faculty (11\%) to believe that graduate students plagiarized written assignments with some degree of regularity, $\chi^{2}(1, N=201)=4.958, p<.05$. Notwithstanding, no differences were revealed between course setting and the frequency of cheating on exams, wrongfully sharing work with others, and violating academic integrity policies.

Table 13

Bivariate Results for Perceptions of Graduate Students Cheat by Faculty Rank, Course Setting, Level of Students Taught, and Gender $(N=201, d f=1)$.

\begin{tabular}{rrrrr}
\hline Variable & $\begin{array}{r}\text { Graduate } \\
\begin{array}{r}\text { Students Cheat } \\
\text { on Exams }\end{array}\end{array}$ & $\begin{array}{r}\text { Graduate Students } \\
\text { Do Not Cheat on } \\
\text { Exams }\end{array}$ & $\chi^{2}$ & \\
\hline$N(\%)$ & $N(\%)$ &
\end{tabular}

Faculty Rank

$0.104 \quad 0.747$

Tenured/Tenure-track

$11(7.9 \%)$

$4(6.6 \%)$

$129(92.1 \%)$

Non-tenure track 57 (93.4\%)

Course setting

$10(6.5 \%) \quad 145(93.5 \%)$

On campus

$5(10.9 \%)$ $41(89.1 \%)$

Level of students

8 (5.5\%) $\quad 137(94.5 \%)$

$2.852 \quad 0.091$

Undergraduates

$7(12.5 \%)$

$49(87.5 \%)$

Gender

$7.487 \quad .006^{* *}$

Male

93 (97.9\%)

Female $13(12.3 \%)$ $93(87.7 \%)$

Notes: *Significant at .05 level

**Significant at .01 level 
Table 14

Bivariate Results for Perceptions of Graduate Students Plagiarize Written Assignments by Faculty Rank, Course Setting, Level of Students Taught, and Gender $(N=201, d f=1)$.

Variable Graduate Students Graduate Students Do

Plagiarize

Not Plagiarize

Assignments Assignments

$N(\%) \quad N(\%)$

Faculty Rank

Tenured/Tenure-track

Non-tenure track

$7(11.5 \%)$

$119(85 \%)$

$54(88.5 \%)$

Course setting

$17(11 \%)$

$11(23.9 \%)$

138 (89\%)

Hybrid/Online

$35(76.1 \%)$

Level of students

$2.113 \quad 0.146$

Undergraduates

$17(11.7 \%)$

$128(88.3 \%)$

Graduates

$11(19.6 \%)$

$45(80.4 \%)$

Gender

$2.984 \quad 0.084$

Male

$9(9.5 \%)$

$86(90.5 \%)$

Female

19 (17.9\%)

$87(82.1 \%)$

Notes: *Significant at .05 level

**Significant at .01 level 
Table 15

Bivariate Results for Perceptions of Graduate Students Wrongfully Share Work by Faculty Rank, Course Setting, Level of Students Taught, and Gender $(N=201, d f=1)$

\begin{tabular}{|c|c|c|c|c|}
\hline Variable & $\begin{array}{r}\text { Graduate } \\
\text { Students } \\
\text { Wrongfully Share } \\
\text { Work } \\
\end{array}$ & $\begin{array}{l}\text { Graduate Students } \\
\text { Do Not Share Work }\end{array}$ & $\chi^{2}$ & $p$ \\
\hline & $N(\%)$ & $N(\%)$ & & \\
\hline Faculty Rank & & & 3.387 & 0.066 \\
\hline Tenured/Tenure-track & 27 (19.3\%) & $113(80.7 \%)$ & & \\
\hline Non-tenure track & 19 (31.1\%) & 42 (68.9\%) & & \\
\hline Course setting & & & 3.195 & 0.074 \\
\hline On campus & 31 (20\%) & $124(80 \%)$ & & \\
\hline Hybrid/Online & $15(32.6 \%)$ & $31(67.4 \%)$ & & \\
\hline Level of students taught & & & 0.005 & 0.945 \\
\hline Undergraduates & $33(22.8 \%)$ & $112(77.2 \%)$ & & \\
\hline Graduates & $13(23.2 \%)$ & $43(76.8 \%)$ & & \\
\hline Gender & & & 1.583 & 0.208 \\
\hline Male & $18(18.9 \%)$ & 77 (81.1\%) & & \\
\hline Female & $28(26.4 \%)$ & $78(73.6 \%)$ & & \\
\hline
\end{tabular}

Notes: *Significant at .05 level

**Significant at .01 level 
Table 16

Bivariate Results for Perceptions of Graduate Students Violate Integrity Policies by Faculty Rank, Course Setting, Level of Students Taught, and Gender $(N=201, d f=1)$

\begin{tabular}{|c|c|c|c|c|}
\hline Variable & $\begin{array}{r}\text { Graduate Students } \\
\text { Violate Policies }\end{array}$ & $\begin{array}{r}\text { Graduate Students } \\
\text { Do Not Violate } \\
\text { Policies }\end{array}$ & $\chi^{2}$ & $p$ \\
\hline & $N(\%)$ & $N(\%)$ & & \\
\hline Faculty Rank & & & 0.025 & 0.874 \\
\hline Tenured/Tenure-track & $15(10.7 \%)$ & 125 (89.3\%) & & \\
\hline Non-tenure track & $7(11.5 \%)$ & $54(88.5 \%)$ & & \\
\hline \multicolumn{5}{|l|}{ Course setting } \\
\hline On campus & $17(11 \%)$ & 138 (89\%) & 0 & 0.985 \\
\hline Hybrid/Online & $5(10.9 \%)$ & $41(89.1 \%)$ & & \\
\hline Level of students & & & 0.193 & 0.661 \\
\hline Undergraduates & $15(10.3 \%)$ & $130(89.7 \%)$ & & \\
\hline Graduates & $7(12.5 \%)$ & $49(87.5 \%)$ & & \\
\hline Gender & & & 3.961 & $0.047^{*}$ \\
\hline Male & $6(6.3 \%)$ & $89(93.7 \%)$ & & \\
\hline Female & $16(15.1 \%)$ & $90(84.9 \%)$ & & \\
\hline
\end{tabular}

Notes: *Significant at .05 level

$* *$ Significant at .01 level

\section{Perceptions of Academic Integrity Polices}

The analyses revealed that faculty rank, course setting, and gender were not associated with faculty understanding and support of the academic integrity policies, severity of the policies, or policy effectiveness. Notwithstanding, faculty understanding of academic integrity policies varied by the level of students taught, $\chi^{2}(1, N=201)=$ 5.151, $p$ <.05; faculty who taught undergraduate students were more likely than those teaching graduate students to understand academic integrity policies (91.7\% and 80.4\%, respectively). 


\section{Perceptions of Institutional Responses to Policy Violations}

The results for bivariate analyses of faculty understanding of institutional responses by the independent variables are presented in Tables 17 through 19. Chisquare analyses revealed a statistically significant association between faculty rank and perceptions of administrative support and encouragement of faculty who report policy violations, $\chi^{2}(1, N=201)=4.102, p<.05$. Non-tenured faculty were significantly more likely than their tenured/tenure-track counterparts to perceive the university administration as supportive and encouraging (83.6\% and 70\%, respectively). They were also significantly more likely (90.2\%) than tenured/tenure-track faculty (73.6\%) to perceive their deans as supportive and encouraging, $\left.\chi^{2}(1, N=201)=6.956, p<.01\right)$. None of the remaining independent variables bore significant relationships with faculty perceptions of institutional responses to policy violations. 
Table 17

Bivariate Results for Perceptions of Administrative Support by Faculty Rank, Course Setting, Level of Students Taught, and Gender $(N=201, d f=1)$.

\begin{tabular}{|c|c|c|c|c|}
\hline Variable & $\begin{array}{r}\text { Administration } \\
\text { Supportive and } \\
\text { Encouraging }\end{array}$ & $\begin{array}{r}\text { Administration } \\
\text { Neither Supportive } \\
\text { Nor Encouraging }\end{array}$ & $\chi^{2}$ & $p$ \\
\hline & $N(\%)$ & $N(\%)$ & & \\
\hline Faculty Rank & & & 4.102 & $0.043^{*}$ \\
\hline Tenured/Tenure-track & $98(70 \%)$ & $42(30 \%)$ & & \\
\hline Non-tenure track & $51(83.6 \%)$ & $10(16.5 \%)$ & & \\
\hline Course setting & & & 0.001 & 0.970 \\
\hline On campus & 115 (74.2\%) & $40(25.8 \%)$ & & \\
\hline Hybrid/Online & 34 (73.9\%) & $12(26.1 \%)$ & & \\
\hline Level of students & & & 0.295 & 0.587 \\
\hline Undergraduates & 109 (75.2\%) & $36(24.8 \%)$ & & \\
\hline Graduates & 40 (71.4\%) & $16(28.6 \%)$ & & \\
\hline Gender & & & 0.035 & 0.852 \\
\hline Male & $71(74.7 \%)$ & $24(25.3 \%)$ & & \\
\hline Female & $78(73.6 \%)$ & $28(26.4 \%)$ & & \\
\hline
\end{tabular}

Notes: *Significant at .05 level

**Significant at .01 level 
Table 18

Bivariate Results for Perceptions of Dean Support by Faculty Rank, Course Setting, Level of Students Taught, and Gender $(N=201, d f=1)$.

\begin{tabular}{|c|c|c|c|c|}
\hline Variable & $\begin{array}{l}\text { Dean Supportive } \\
\text { and Encouraging }\end{array}$ & $\begin{array}{r}\text { Dean Neither } \\
\text { Supportive nor } \\
\text { Encouraging } \\
\end{array}$ & $\chi^{2}$ & $p$ \\
\hline & $N(\%)$ & $N(\%)$ & & \\
\hline Faculty Rank & & & 6.956 & $0.008 * *$ \\
\hline Tenured/Tenure-track & 103 (73.6\%) & $37(26.4 \%)$ & & \\
\hline Non-tenure track & 55 (90.2\%) & $6(9.8 \%)$ & & \\
\hline Course setting & & & 0.225 & 0.635 \\
\hline On campus & 123 (79.4\%) & $32(20.6 \%)$ & & \\
\hline Hybrid/Online & 35 (76.1\%) & $11(23.9 \%)$ & & \\
\hline Level of students & & & 2.379 & 0.123 \\
\hline Undergraduates & 118 (81.4\%) & 27 (18.6\%) & & \\
\hline Graduates & 40 (71.4\%) & $16(28.6 \%)$ & & \\
\hline Gender & & & 1.311 & 0.252 \\
\hline Male & 78 (82.1\%) & $17(17.9 \%)$ & & \\
\hline Female & $80(75.5 \%)$ & $26(24.5 \%)$ & & \\
\hline
\end{tabular}

Notes: *Significant at .05 level

**Significant at .01 level 
Table 19

Bivariate Results for Perceptions of Chair Support by Faculty Rank, Course Setting, Level of Students Taught, and Gender $(N=201, d f=1)$

\begin{tabular}{|c|c|c|c|c|}
\hline Variable & $\begin{array}{r}\text { Chair } \\
\text { Supportive } \\
\text { and } \\
\text { Encouraging } \\
\end{array}$ & $\begin{array}{r}\text { Chair Not } \\
\text { Supportive and } \\
\text { Encouraging }\end{array}$ & $\chi^{2}$ & $p$ \\
\hline & $N(\%)$ & $N(\%)$ & & \\
\hline Faculty Rank & & & 0.507 & 0.476 \\
\hline Tenured/Tenure-track & $111(79.3 \%)$ & $29(20.7 \%)$ & & \\
\hline Non-tenure track & 51 (83.6\%) & $10(16.4 \%)$ & & \\
\hline Course setting & & & 0.776 & 0.378 \\
\hline On campus & 127 (81.9\%) & $28(18.1 \%)$ & & \\
\hline Hybrid/Online & 35 (76.1\%) & $11(23.9 \%)$ & & \\
\hline Level of students taught & & & 1.555 & 0.212 \\
\hline Undergraduates & 120 (82.8\%) & $25(17.2 \%)$ & & \\
\hline Graduates & $42(75 \%)$ & $14(25 \%)$ & & \\
\hline Gender & & & 0.262 & 0.609 \\
\hline Male & 78 (82.1\%) & 17 (17.9\%) & & \\
\hline Female & $84(79.2 \%)$ & $22(20.8 \%)$ & & \\
\hline
\end{tabular}

Notes: *Significant at .05 level

**Significant at .01 level 


\section{Understanding of Self-Plagiarism}

Tables 20 through 23 present the bivariate analyses of faculty understanding of self-plagiarism by the independent variables. Chi-square tests revealed that there were statistically significant differences between faculty rank and whether or not faculty believed that students who fail to secure permission prior to recycling their work were self-plagiarizing, $\chi^{2}(1, N=201)=4.702, p<.05$, as well as between rank and whether or not reusing material that was originally part of a group assignment amounted to selfplagiarism, $\chi^{2}(1, N=201)=3.883, p<.05$. The majority of tenured/tenure-track and non-tenured faculty believed that students who failed to secure permission to recycle their work were self-plagiarizing (75\% and $88.5 \%$, respectively) and that submitting work that originated from a previously submitted group assignment constituted self-plagiarism (78.6\% and 90.2\%, respectively); however, non-tenured faculty were significantly more likely to have these beliefs. The relationships between faculty rank and reusing a completed paper or part of a paper were not statistically significant.

Although the analyses revealed that faculty understanding of self-plagiarism was not associated with academic level of students taught (undergraduate versus graduate students) or course setting (i.e., on campus versus online), gender, however, was associated with faculty perceptions of self-plagiarism. Female faculty were significantly more likely than their male counterparts to believe that instructor permission $(85.8 \%$ and $71.6 \%$, respectively) was needed to avoid self-plagiarism, $\chi^{2}(1, N=201)=6.172, p<.05$, and that students who recycled previously submitted papers, in their entirety, had selfplagiarized (91.5\% of women and $81.1 \%$ of men), $\chi^{2}(1, N=201)=4.711, p<.05$. 
Table 20

Bivariate Results for Permission Needed to Recycle Previously Submitted Assignment by Faculty Rank, Course Setting, Level of Students Taught, and Gender $(N=201, d f=1)$.

\begin{tabular}{lrrrr}
\hline Variable & $\begin{array}{r}\text { Permission Needed to } \\
\text { Recycle }\end{array}$ & $\begin{array}{r}\text { Permission Not } \\
\text { Needed to Recycle }\end{array}$ & $\chi^{2}$ & $p$ \\
\hline Faculty Rank & $N(\%)$ & $N(\%)$ & & \\
$\begin{array}{l}\text { Tenured/Tenure-track } \\
\text { Non-tenure track }\end{array}$ & $105(75 \%)$ & $35(25 \%)$ & & \\
& $54(88.5 \%)$ & $7(11.5 \%)$ & & \\
Course setting & & & & \\
On campus & $122(78.7 \%)$ & $33(21.3 \%)$ & & \\
Hybrid/Online & $37(80.4 \%)$ & $9(19.6 \%)$ & & \\
& & & & \\
Level of students & & & & \\
Undergraduates & $115(79.3 \%)$ & $30(20.7 \%)$ & & \\
Graduates & $44(78.6 \%)$ & $12(21.4 \%)$ & & \\
& & & & \\
Gender & & & & \\
Male & & & & \\
Female & $68(71.6 \%)$ & $15(14.2 \%)$ & & \\
\hline
\end{tabular}

Notes: *Significant at .05 level

**Significant at .01 level 
Table 21

Bivariate Results for Reusing Group Work by Faculty Rank, Course Setting, Level of Students Taught, and Gender $(N=201, d f=1)$.

\begin{tabular}{|c|c|c|c|c|}
\hline Variable & $\begin{array}{r}\text { Reusing Group } \\
\text { Work is Self- } \\
\text { Plagiarism } \\
\end{array}$ & $\begin{array}{c}\text { Reusing Group } \\
\text { Work Not Self- } \\
\text { Plagiarism } \\
\end{array}$ & $\chi^{2}$ & $p$ \\
\hline & $N(\%)$ & $N(\%)$ & & \\
\hline Faculty Rank & & & 3.883 & $.049 *$ \\
\hline Tenured/Tenure-track & $110(78.6 \%)$ & $30(21.4 \%)$ & & \\
\hline Non-tenure track & 55 (90.2\%) & $6(9.8 \%)$ & & \\
\hline Course setting & & & 0.294 & .588 \\
\hline On campus & $126(81.3 \%)$ & $29(18.7 \%)$ & & \\
\hline Hybrid/Online & 39 (84.8\%) & $7(15.2 \%)$ & & \\
\hline Level of students & & & 0.000 & .990 \\
\hline Undergraduates & 119 (82.1\%) & $26(17.9 \%)$ & & \\
\hline Graduates & $46(82.1 \%)$ & $10(17.9 \%)$ & & \\
\hline Gender & & & 0.132 & .717 \\
\hline Male & 77 (81.1\%) & 18 (18.9\%) & & \\
\hline Female & $88(83 \%)$ & $18(17 \%)$ & & \\
\hline
\end{tabular}

Notes: *Significant at .05 level

**Significant at .01 level 
Table 22

Bivariate Results for Reusing Completed Paper is Self-Plagiarism by Faculty Rank, Course Setting, Level of Students Taught, and Gender $(N=201, d f=1)$.

\begin{tabular}{|c|c|c|c|c|}
\hline Variable & $\begin{array}{r}\text { Reusing } \\
\text { Completed } \\
\text { Paper is Self- } \\
\text { Plagiarism }\end{array}$ & $\begin{array}{r}\text { Reusing } \\
\text { Completed Paper } \\
\text { Not Self- } \\
\text { Plagiarism } \\
\end{array}$ & $\chi^{2}$ & $p$ \\
\hline & $N(\%)$ & $N(\%)$ & & \\
\hline Faculty Rank & & & 3.560 & .059 \\
\hline Tenured/Tenure-track & 117 (83.6\%) & $23(16.4 \%)$ & & \\
\hline Non-tenure track & 57 (93.4\%) & $4(6.6 \%)$ & & \\
\hline Course setting & & & 0.337 & .562 \\
\hline On campus & $133(85.8 \%)$ & $22(14.2 \%)$ & & \\
\hline Hybrid/Online & $41(89.1 \%)$ & 5 (10.9\%) & & \\
\hline Level of students & & & 1.307 & .253 \\
\hline Undergraduates & $128(88.3 \%)$ & $17(11.7 \%)$ & & \\
\hline Graduates & $46(82.1 \%)$ & $10(17.9 \%)$ & & \\
\hline Gender & & & 4.711 & $.030 *$ \\
\hline Male & 77 (81.1\%) & $18(18.9 \%)$ & & \\
\hline Female & 97 (91.5\%) & $9(8.5 \%)$ & & \\
\hline
\end{tabular}

Notes: *Significant at .05 level

**Significant at .01 level 
Table 23

Bivariate Results for Reusing Part of a Previously Submitted Paper by Faculty Rank, Course Setting, Level of Students Taught, and Gender $(N=201, d f=1)$

\begin{tabular}{|c|c|c|c|c|}
\hline Variable & $\begin{array}{r}\text { Reusing Part } \\
\text { of Paper is } \\
\text { Self- } \\
\text { Plagiarism }\end{array}$ & $\begin{array}{l}\text { Reusing Part of } \\
\text { Paper Not Self- } \\
\text { Plagiarism }\end{array}$ & $\chi^{2}$ & $p$ \\
\hline & $N(\%)$ & $N(\%)$ & & \\
\hline Faculty Rank & & & 0.8 & .371 \\
\hline Tenured/Tenure-track & $92(65.7 \%)$ & 48 (34.3\%) & & \\
\hline Non-tenure track & $44(72.1 \%)$ & 17 (27.9\%) & & \\
\hline Course setting & & & 0.453 & .501 \\
\hline On campus & $103(66.5 \%)$ & 52 (33.5\%) & & \\
\hline Hybrid/Online & $33(71.7 \%)$ & $13(28.3 \%)$ & & \\
\hline Level of students taught & & & 0.404 & .525 \\
\hline Undergraduates & 100 (69\%) & 45 (31\%) & & \\
\hline Graduates & 36 (64.3\%) & 20 (35.7\%) & & \\
\hline Gender & & & 0.149 & 699 \\
\hline Male & 63 (66.3\%) & 32 (33.7\%) & & \\
\hline Female & $73(68.9 \%)$ & $33(31.1 \%)$ & & \\
\hline
\end{tabular}

\section{Multivariate Analyses}

I used hierarchical log-linear analyses to test the null hypotheses of no association between the variables measuring faculty perceptions of academic integrity policies, perceptions of institutional responses, and understanding of self-plagiarism. The results are listed below.

\section{Analysis of Hypothesis 1}

Hypothesis 1 posited that there was no relationship among the variables used to measure faculty perceptions of academic integrity policies. The interaction between the following variables were examined: severity of institutional penalties for academic 
dishonesty, faculty support of academic integrity policies, faculty understanding of those policies, and policy effectiveness.

The $\chi^{2}$ result of the final model indicated a good fit between observed frequencies and expected frequencies generated by the model (Likelihood Ratio $\chi^{2}=3.253, p>.05$ ). The tests of Partial Associations revealed the following significant interactions: the three way interaction of policy effectiveness, severity of penalties, and faculty understanding of the policies $\left(\chi^{2}=9.553, p<.01\right)$ and several two-way interactions of policy effectiveness and faculty support $\left(\chi^{2}=14.569, p<.001\right)$, severity of penalties and faculty support $\left(\chi^{2}=10.915, p<.01\right)$, faculty support and faculty understanding of policies $\left(\chi^{2}=\right.$ $11.751, p<.01)$, and policy effectiveness and severity of penalties $\left(\chi^{2}=10.168, p<.001\right)$. The crosstabulation tables revealed that faculty with both low understanding and low perceptions of policy effectiveness were more likely to perceive the penalties for academic dishonesty as less severe (58.8\%). Those respondents with low understanding who perceive policy effectiveness as moderate or severe were equally as likely to categorize the penalties as being low or moderate/high ( $50 \%$ each). Faculty-respondents who possessed moderate/high understanding of institutional policies but perceived those policies as lacking in efficacy were significantly more likely to believe that the penalties were severe (57.9\%) while those with moderate/high understanding who also believed that the policies were effective were more likely to perceive the penalties as severe (95\%).

The two-way interaction of Effectiveness*Severity $\left(\chi^{2}=10.168, p<.01\right)$ was significant. Faculty who perceived institutional policies as lacking in efficacy showed similar numbers in terms of rating the penalties as low or moderate/high (47.3\% and 
52.7\%, respectively). However, faculty who construed the policies as effective were more likely to perceive the severity of the penalties as moderate/high (93.2\%).

The two-way interaction of Effectiveness*Faculty Support $\left(\chi^{2}=14.569, p<.01\right)$ was significant. The crosstabulation of faculty support by policy effectiveness revealed significantly different associations. Faculty who perceived the policies as effective were more likely to report high levels of support for those policies (98.6\%) compared to faculty who perceived academic integrity policies as ineffective (60\%).

The two-way interaction of Severity*Support $\left(\chi^{2}=10.915, p<.01\right)$ was significant. Faculty-respondents who rated the severity of the penalties as moderate/high were more likely (96.4\%) than those who did not rate penalties as severe (50\%) to report high levels of policy support. Finally, the two-way interaction of Support*Understanding $\left(\chi^{2}=13.423, p<.01\right)$ was significant. Faculty who understood institutional policies were more likely (94.4\%) than their counterparts to support those policies as indicated by moderate/high levels of policy support. To the contrary, faculty who did not understand institutional policies were likely to have low levels of support for said policies (60.9\%). Therefore, the null hypothesis of no association was rejected; there were significant associations between the variables used to examine faculty perceptions of academic integrity policies. 
Table 24

K-way and Higher-Order Effects for Faculty Understanding of Academic Integrity Policies

\begin{tabular}{lrrrr}
\hline K-way & K & Df & $\begin{array}{r}\text { Likelihood Ratio } \\
\text { Chi-Square }\end{array}$ & $\begin{array}{r}\text { Pearson } \\
\text { Chi-Square }\end{array}$ \\
\hline K-way and Higher Order Effects & 1 & 15 & $561.447^{* *}$ & $1243.537^{* *}$ \\
& 2 & 11 & $161.734^{* *}$ & $823.853^{* *}$ \\
& 3 & 5 & 10.622 & 10.951 \\
K-way Effects & 4 & 1 & 0.565 & 0.295 \\
& 1 & 4 & $399.713^{* *}$ & $419.684^{* *}$ \\
& 2 & 6 & $151.112^{* *}$ & $812.902^{* *}$ \\
& 3 & 4 & $10.058^{*}$ & $10.657^{*}$ \\
& 4 & 1 & 0.565 & 0.587 \\
\hline
\end{tabular}

Notes: *Significant at .05 level

**Significant at .01 level

Table 25

Partial Associations for Faculty Understanding of Academic Integrity Policies.

\begin{tabular}{lr}
\hline Effect $(\mathrm{df}=1)$ & Partial Chi-Square \\
\hline Effective*Severity*Support & 0.501 \\
Effective*Severity*Understanding & $9.553^{* *}$ \\
Effective*Support*Understanding & 0.219 \\
Severity*Support*Understanding & 2.309 \\
Effective*Severity & $10.168^{* *}$ \\
Effective*Support & $14.569 * *$ \\
Severity*Support & $10.915^{* *}$ \\
Effective*Understanding & 2.304 \\
Severity*Understanding & 0.472 \\
Support*Understanding & $11.751^{* *}$ \\
Effective & $42.736^{* *}$ \\
Severity & $89.692^{* *}$ \\
Support & $131.620^{* *}$ \\
Understanding & $135.664^{* *}$ \\
\hline Notes: &
\end{tabular}

Notes: *Significant at .05 level

**Significant at .01 level 
Table 26

Parameter Estimates for Faculty Understanding of Academic Integrity Policies.

\begin{tabular}{lrr}
\hline Effect (Parameter 1) & Estimate & Std. Error \\
\hline Effective*Severity*Support*Understanding & 0.110 & 0.192 \\
Effective*Severity*Support & 0.122 & 0.192 \\
Effective*Severity*Understanding & $-0.385^{*}$ & 0.192 \\
Effective*Support*Understanding & 0.025 & 0.192 \\
Severity*Support*Understanding & 0.068 & 0.192 \\
Effective*Severity & 0.152 & 0.192 \\
Effective*Support & $0.631^{* *}$ & 0.192 \\
Severity*Support & $0.523^{* *}$ & 0.192 \\
Effective*Understanding & 0.059 & 0.192 \\
Severity*Understanding & 0.207 & 0.192 \\
Support*Understanding & $0.617^{* *}$ & 0.192 \\
Effective & 0.258 & 0.192 \\
Severity & -0.249 & 0.192 \\
Support & $-0.575^{* *}$ & 0.192 \\
Understanding & $-0.533^{* *}$ & 0.192 \\
\hline
\end{tabular}

Notes: *Significant at .05 level

$* *$ Significant at .01 level

Table 27

Goodness-of-Fit Tests for Faculty Understanding of Academic Integrity Policies.

\begin{tabular}{lrrr}
\hline & Chi-Square & Df & Sig. \\
\hline Likelihood Ratio & 3.253 & 4 & 0.516 \\
Pearson & 2.059 & 4 & 0.725 \\
\hline
\end{tabular}


Table 28

Effective*Severity*Understanding Crosstabulation.

\begin{tabular}{|c|c|c|c|c|c|}
\hline \multicolumn{3}{|l|}{ Understanding } & \multicolumn{3}{|c|}{ Severity } \\
\hline & & & Low & Moderate/high & Total \\
\hline \multirow{3}{*}{ Low } & \multirow{3}{*}{ Effective (\% within Effective) } & Low & $10(58.8 \%)$ & $7(41.2 \%)$ & $17(100 \%)$ \\
\hline & & Moderate/high & $3(50.0 \%)$ & $3(50.0 \%)$ & $6(100 \%)$ \\
\hline & & Total & $13(56.5 \%)$ & $10(43.5 \%)$ & $23(100 \%)$ \\
\hline \multirow{3}{*}{ Moderate/high } & \multirow{3}{*}{ Effective (\% within Effective) } & Low & $16(42.1 \%)$ & $22(57.9 \%)$ & $38(100 \%)$ \\
\hline & & Moderate/high & $7(5.0 \%)$ & $133(95.0 \%)$ & $140(100 \%)$ \\
\hline & & Total & $23(12.9 \%)$ & $155(87.1 \%)$ & $178(100 \%)$ \\
\hline \multirow{3}{*}{ Total } & & Low & $26(47.3 \%)$ & $29(52.7 \%)$ & $55(100 \%)$ \\
\hline & Effective (\% within Effective) & Moderate/high & $10(6.8 \%)$ & $136(93.2 \%)$ & $156(100 \%)$ \\
\hline & Total & & $36(17.9 \%)$ & $165(82.1 \%)$ & $201(100 \%)$ \\
\hline
\end{tabular}

Table 29

Effective*Severity Crosstabulation.

\begin{tabular}{llrrr}
\hline & \multicolumn{3}{c}{ Severity } \\
\hline & & Low & Moderate/high & Total \\
Effective & Low & $26(47.3 \%)$ & $29(52.7 \%)$ & $55(100 \%)$ \\
(\% within Effective) & Moderate/high & $10(6.8 \%)$ & $136(93.2 \%)$ & $146(100 \%)$ \\
\hline
\end{tabular}


Table 30

Effective*Support Crosstabulation.

\begin{tabular}{llrrr}
\hline & \multicolumn{3}{c}{ Support } \\
\hline & & Low & Moderate/high & Total \\
Effective & Low & $22(40.0 \%)$ & $33(60.0 \%)$ & $55(100 \%)$ \\
(\% within Effective) & Moderate/high & $2(1.4 \%)$ & $144(98.6 \%)$ & $146(100 \%)$ \\
\hline
\end{tabular}

Table 31

Severity*Support Crosstabulation.

\begin{tabular}{llrrr}
\hline & \multicolumn{3}{c}{ Support } \\
& & Low & Moderate/high & Total \\
& Low & $18(50.0 \%)$ & $18(50.0 \%)$ & $36(100 \%)$ \\
Severity & Moderate/high & $6(3.6 \%)$ & $159(96.4 \%)$ & $165(100 \%)$ \\
(\% within Severity) & Total & $24(11.9 \%)$ & $177(88.1 \%)$ & $201(100 \%)$ \\
\hline
\end{tabular}

Table 32

Understanding*Support Crosstabulation.

\begin{tabular}{llrrr}
\hline & \multicolumn{3}{c}{ Support } \\
\hline & & Low & Moderate/high & Total \\
& Low & $14(60.9 \%)$ & $9(39.1 \%)$ & $23(100 \%)$ \\
Understanding & Moderate/high & $10(5.6 \%)$ & $168(94.4 \%)$ & $178(100 \%)$ \\
(\% within Understanding) & Total & $24(11.9 \%)$ & $177(88.1 \%)$ & $201(100 \%)$ \\
\hline
\end{tabular}




\section{Analysis of Hypothesis 2}

Hypothesis 2 suggested that the variables used to measure faculty perceptions of institutional responses to academic integrity violations were not related. The interactions between the following variables were analyzed: faculty support and encouragement to report instances of student academic misconduct as originating from the department chair, the dean, and university administrators, respectively.

The K-Way and Higher-Order Effects table showed that at least one of the twoway associations was significant. The test of the single three-way association was not significant. For the final model, the SPSS program selected Adminsupport*Chairsupport, Adminsupport*Deansupport, Chairsupport*Deansupport. The $\chi^{2}$ result of the final model (Adminsupport*Chairsupport, Adminsupport*Deansupport, Chairsupport*Deansupport) indicated a good fit between observed frequencies and expected frequencies generated by the model (Likelihood Ratio $\chi^{2}=0.088, p>.05$ ).

The Partial Associations table indicated that the interaction between Administrator Support and Chair Support (Partial $\left.\chi^{2}=8.279, p<.001\right)$ was significant. Faculty who perceived administrators as supportive were more likely to perceive their chairs as supportive (96.0\%); notwithstanding, 36.5\% of faculty who believed that their administrators were neither supportive nor encouraging considered their chairs to be supportive.

The association between Administrator Support and Dean Support $\left(\right.$ Partial $\chi^{2}=$ 52.194, $p<.001$ ) was significant. Faculty who perceived administrators as being supportive and encouraging in reporting academically dishonest behaviors were likely to perceive deans in the same manner (98\%). Notwithstanding, $23.1 \%$ of faculty who did 
not perceive their administrators as supportive still believed that their deans supported and encouraged reporting practices. Finally, the two-way association between Chair Support and Dean Support (Partial $\chi^{2}=12.614, p<.001$ ) was significant. Nearly 93\% of faculty who perceived their chairs as supportive and encouraging perceived their deans in the same manner. Nevertheless, $20.5 \%$ of faculty who did not perceive chairs as supportive perceived their deans to be both supportive and encouraging of faculty reporting academic integrity violations.

In light of these findings, the null hypothesis of no association between the variables used to examine faculty perceptions of institutional responses to academic integrity policy violations was rejected; these variables were related.

Table 33

K-way and Higher-Order Effects for Faculty Perceptions of Institutional Support.

\begin{tabular}{lrrrr}
\hline K-way & K & df & $\begin{array}{r}\text { Likelihood Ratio } \\
\text { Chi-Square }\end{array}$ & $\begin{array}{r}\text { Pearson } \\
\text { Chi-Square }\end{array}$ \\
\hline K-way and Higher Order Effects & 1 & 7 & $414.689^{* *}$ & $634.861^{* *}$ \\
& 2 & 4 & $215.052^{* *}$ & $442.735^{* *}$ \\
K-way Effects & 3 & 1 & 0.088 & 0.092 \\
& 1 & 3 & $199.637^{* *}$ & $192.126^{* *}$ \\
& 2 & 3 & $214.964^{* *}$ & $442.643^{* *}$ \\
& 3 & 1 & 0.088 & 0.092 \\
\hline
\end{tabular}

Notes: *Significant at .05 level

**Significant at .01 level

Table 34

Partial Associations for Faculty Perceptions of Institutional Support.

\begin{tabular}{lr} 
Effect $(\mathrm{df}=1)$ & Partial Chi-Square \\
\hline Administrationsupport*Chairsupport & $8.279^{* *}$ \\
Administrationsupport*Deansupport & $52.194^{* *}$ \\
Chairsupport*Deansupport & $12.614^{* *}$ \\
Administrationsupport & $48.822^{* *}$ \\
Chairsupport & $80.856^{* *}$ \\
Deansupport & $69.960^{* *}$ \\
\hline Notes: *Significant at .05 level & \\
&
\end{tabular}


Table 35

Parameter Estimates for Faculty Perceptions of Institutional Support.

\begin{tabular}{lrr}
\hline Effect (Parameter 1) & Estimate & Std. Error \\
\hline Administrationsupport*Chairsupport*Deansupport & -0.084 & 0.167 \\
Administrationsupport*Chairsupport & $0.478^{* *}$ & 0.167 \\
Aministrationsupport*Deansupport & $0.950^{* *}$ & 0.167 \\
Chairsupport*Deansupport & $0.600^{* *}$ & 0.167 \\
Administrationsupport & 0.162 & 0.167 \\
Chairsupport & $-0.451^{* *}$ & 0.167 \\
Deansupport & $-0.384^{*}$ & 0.167 \\
\hline
\end{tabular}

Notes: * Significant at 0.05 level

** Significant at .01 level

Table 36

Goodness-of-Fit Tests for Faculty Perceptions of Institutional Support.

\begin{tabular}{lrrr}
\hline & Chi-Square & df & Sig. \\
\hline Likelihood Ratio & 0.088 & 1 & 0.767 \\
Pearson & 0.092 & 1 & 0.762 \\
\hline
\end{tabular}


Table 37

Administrationsupport*Chairsupport Crosstabulation.

\begin{tabular}{llrrr}
\hline \multicolumn{3}{c}{ Chair Support } \\
\hline & & Not supportive & Supportive & Total \\
& Not supportive & $33(63.5 \%)$ & $19(36.5 \%)$ & $52(100 \%)$ \\
Administrative Support & Supportive & $6(4.0 \%)$ & $143(96.0 \%)$ & $149(100 \%)$ \\
$(\%$ within Support) & Total & $39(19.4 \%)$ & $162(80.6 \%)$ & $201(100 \%)$ \\
\hline
\end{tabular}

Table 38

Administrationsupport*Deansupport Crosstabulation.

\begin{tabular}{llrrr}
\hline & & \multicolumn{3}{c}{ Dean Support } \\
\hline & & Not supportive & Supportive & Total \\
& Not supportive & $40(76.9 \%)$ & $12(23.1 \%)$ & $52(100 \%)$ \\
Administrative Support & Supportive & $3(2.0 \%)$ & $146(98.0 \%)$ & $149(100 \%)$ \\
(\% within Support) & Total & $43(21.4 \%)$ & $158(78.6 \%)$ & $201(100 \%)$ \\
\hline
\end{tabular}

Table 39

Chairsupport*Deansupport Crosstabulation.

\begin{tabular}{llrrr}
\hline & & \multicolumn{3}{c}{ Dean Support } \\
\hline & & Not supportive & Supportive & Total \\
& Not supportive & $31(79.5 \%)$ & $8(20.5 \%)$ & $39(100 \%)$ \\
Chair Support & Supportive & $12(7.4 \%)$ & $150(92.6 \%)$ & $162(100 \%)$ \\
(\% within Support) & Total & $43(21.4 \%)$ & $158(78.6 \%)$ & $201(100 \%)$ \\
\hline
\end{tabular}




\section{Analysis of Hypothesis 3}

Hypothesis 3 stated that there was no relationship among the variables used to measure faculty understanding of self-plagiarism. I examined the interaction between the following variables: students obtaining faculty permission to recycle their work, students reusing part of a previous paper for a new assignment without citing the previous paper, students reusing assignments that were completed by a group of students in a course, and students reusing a completed paper for a new assignment.

The K-Way and Higher-Order Effects table suggested that at least one of the twoway associations was statistically significant; yet, neither of the tests of three-way associations were significant. For the final model, the SPSS program selected Reusegroup*Permission, Reuseall*Permission, Reuseall*Reusegroup, and Reusegroup*Reusepart. The $\chi^{2}$ result of the final model indicated a good fit between the observed frequencies and expected frequencies generated by the model (Likelihood Ratio $\left.\chi^{2}=6.345, p>.05\right)$.

The Partial Associations table indicated that Reuseall*Reusegroup $\left(\right.$ Partial $\chi^{2}=$ $14.438, p<.001$ ) was significant. Faculty who agreed that reusing a completed paper for a new assignment constituted self-plagiarism were more likely to perceive reusing assignments that were completed by a group of students as self-plagiarism (90.2\%). However, nearly $30 \%$ of faculty who disagreed with the idea that recycling a paper in its entirety constituted self-plagiarism also believed that submitting assignments that were completed by a group of students was self-plagiarism. Additionally, the interactions between Reusegroup*Reusepart $\left(\right.$ Partial $\left.\chi^{2}=9.369, p<.01\right)$ and Reuseall*Permission (Partial $\left.\chi^{2}=24.490, p<.001\right)$ were statistically significant. Faculty who agreed that 
reusing work that was originally submitted as a group assignment amounted to selfplagiarism were more likely to agree (73.3\%) that reusing part of a previously submitted assignment, without citing the previous paper, constituted self-plagiarism. Faculty who believed that reusing a completed paper for a new written assignment amounted to selfplagiarism were more likely to agree that students needed permission to double-dip assignments and, thus, avoid self-plagiarism (87.9\%). Nevertheless, $22.2 \%$ of faculty who believed that recycling an entire paper did not, in and of itself, constitute selfplagiarism believed that students needed to obtain faculty permission prior to recycling the assignment. Finally, the interaction between Reusegroup*Permission (Partial $\chi^{2}=$ 7.193, $p<.05$ ) was significant. Faculty who agreed that reusing previously submitted group work constituted self-plagiarism were more likely to believe (87.3\%) that students who failed to secure faculty permission prior to double-dipping had self-plagiarized. Notwithstanding, $41.7 \%$ of those who disagreed with the plagiarism categorization of reusing previously submitted group work still believed that students needed faculty permission to recycle their work and, thus, prevent self-plagiarism.

Overall, the results of the Parameter Estimates confirmed the results from the Partial Associations except for the two-way interaction between Reusegroup and Reusepart. However, it could not be determined whether the faculty belief that reusing a part of a previously submitted assignment constituted self-plagiarism truly varied by faculty belief that reusing work that was originally submitted as a group assignment amounted to self-plagiarism until the Pearson chi-square was determined to be significant. In the Chi Square Tests table, the Pearson chi-square value of 13.544 and the 
test of significance (Asymp. Sig.) value of $p<.001$ showed that the differences in perceptions of self-plagiarism by type of assignment were statistically significant.

Based upon these findings, the null hypothesis was rejected; the variables used to examine faculty perceptions of self-plagiarism were related.

Table 40

K-way and Higher-Order Effects for Faculty Understanding of Self-Plagiarism

\begin{tabular}{llrrr}
\hline \multirow{2}{*}{ K-way } & K & df & $\begin{array}{r}\text { Likelihood Ratio } \\
\text { Chi-Square }\end{array}$ & $\begin{array}{r}\text { Pearson } \\
\text { Chi-Square }\end{array}$ \\
\hline K-way and Higher Order Effects & 1 & 15 & $426.714^{* *}$ & $781.687^{* *}$ \\
& 2 & 11 & $118.758^{* *}$ & $347.765^{* *}$ \\
& 3 & 5 & 3.733 & 3.542 \\
K-way Effects & 4 & 1 & 0.004 & 0.004 \\
& 1 & 4 & $307.956^{* *}$ & $433.922^{* *}$ \\
& 2 & 6 & $115.025^{* *}$ & $344.223^{* *}$ \\
& 3 & 4 & 3.729 & 3.537 \\
& 4 & 1 & 0.004 & 0.004 \\
\hline
\end{tabular}

Notes: *Significant at .05 level

**Significant at .01 level

Table 41

Partial Associations for Faculty Understanding of Self-Plagiarism.

\begin{tabular}{lr} 
Effect $(\mathrm{df}=1)$ & Partial Chi-Square \\
\hline Reuseall*Reusegroup*Reusepart & 2.208 \\
Reuseall*Reusegroup*Permission & 0.433 \\
Reuseall*Reusepart*Permission & 0.647 \\
Reusegroup*Reusepart*Permission & 0.024 \\
Reuseall*Reusegroup & $14.438 * *$ \\
Reuseall*Reusepart & 1.127 \\
Reusegroup*Reusepart & $9.369 * *$ \\
Reuseall*Permission & $24.49 * *$ \\
Reusegroup*Permission & $7.193 * *$ \\
Reusepart*Permission & 2.447 \\
Reuseall & $120.043 * *$ \\
Reusegroup & $89.692 * *$ \\
Reusepart & $25.629 * *$ \\
Permission & $72.592 * *$ \\
\hline Notes: *Significant at .05 level & \\
$*$ **Significant at .01 level &
\end{tabular}


Table 42

Parameter Estimates for Faculty Understanding of Self-Plagiarism.

\begin{tabular}{lrr}
\hline Effect (Parameter 1) & Estimate & Std. Error \\
\hline Reuseall*Reusegroup*Reusepart*Permission & 0.001 & 0.137 \\
Reuseall*Reusegroup*Reusepart & -0.215 & 0.137 \\
Reuseall*Reusegroup*Permission & 0.055 & 0.137 \\
Reuseall*Reusepart*Permission & 0.106 & 0.137 \\
Reusegroup*Reusepart*Permission & 0.013 & 0.137 \\
Reuseall*Reusegroup & $0.493 * *$ & 0.137 \\
Reuseall*Reusepart & 0.135 & 0.137 \\
Reusegroup*Reusepart & 0.229 & 0.137 \\
Reuseall*Permission & $0.633 * *$ & 0.137 \\
Reusegroup*Permission & $0.393 * *$ & 0.137 \\
Reusepart*Permission & -0.093 & 0.137 \\
Reuseall & $-0.541 * *$ & 0.137 \\
Reusegroup & $-0.301 *$ & 0.137 \\
Reusepart & -0.122 & 0.137 \\
Permission & -0.185 & 0.137 \\
\hline
\end{tabular}

Notes: *Significant at .05 level

**Significant at .01 level

Table 43

Goodness-of-Fit Tests for Faculty Understanding of Self-Plagiarism.

\begin{tabular}{lrrr}
\hline & Chi-Square & Df & Sig. \\
\hline Likelihood Ratio & 6.345 & 7 & 0.5 \\
Pearson & 6.462 & 7 & 0.487 \\
\hline
\end{tabular}

Table 44

Reuseall*Reusegroup Crosstabulation.

\begin{tabular}{llrrr}
\hline \multicolumn{4}{c}{ Reusegroup Assignment } \\
\hline & Disagree & Agree & Total \\
& Disagree & $19(70.4 \%)$ & $8(29.6 \%)$ & $27(100 \%)$ \\
Reuseall & Agree & $17(9.8 \%)$ & $157(90.2 \%)$ & $174(100 \%)$ \\
(\% within Reuseall) & Total & $36(17.9 \%)$ & $165(82.1 \%)$ & $201(100 \%)$ \\
\hline
\end{tabular}


Table 45

Reusegroup*Reusepart Crosstabulation

\begin{tabular}{llrrr}
\hline \multicolumn{5}{c}{ Reusepart } \\
\hline & Disagree & $21(58.3 \%$ & $15(41.7 \%)$ & $36(100 \%)$ \\
& Agree & $44(26.7 \%)$ & $121(73.3 \%)$ & $165(100 \%)$ \\
Reusegroup & Total & $65(32.3 \%)$ & $136(67.7 \%)$ & $201(100 \%)$ \\
\hline
\end{tabular}

Table 46

Chi-Square Table (Reusegroup * Reusepart).

\begin{tabular}{lr}
\hline Tests $(\mathrm{df}=1)$ & Value \\
\hline Pearson's Chi-Square & $13.544^{* *}$ \\
Continuity Correction & $12.135^{* *}$ \\
Likelihood Ratio & $12.742^{* *}$ \\
Linear-by-Linear Association & $13.476^{* *}$ \\
N of Valid Cases & 201 \\
\hline
\end{tabular}

Table 47

Reuseall*Permission Crosstabulation.

\begin{tabular}{llrrr}
\hline \multicolumn{5}{c}{ Permission } \\
\hline & Disagree & $21(77.8 \%)$ & $6(22.2 \%)$ & $27(100 \%)$ \\
Reuseall & Agree & $21(12.1 \%)$ & $153(87.9 \%)$ & $174(100 \%)$ \\
(\% within Reuseall) & Total & $42(20.9 \%)$ & $159(79.1 \%)$ & $201(100 \%)$ \\
\hline
\end{tabular}

Table 48

Reusegroup*Permission Crosstabulation.

\begin{tabular}{llrrr}
\hline \multicolumn{5}{c}{ Permission } \\
& & Disagree & Agree & Total \\
& Disagree & $21(58.3 \%)$ & $15(41.7 \%)$ & $36(100 \%)$ \\
Reusegroup & Agree & $21(12.7 \%)$ & $144(87.3 \%)$ & $165(100 \%)$ \\
(\% within Reusegroup) & Total & $42(20.9 \%)$ & $159(79.1 \%)$ & $201(100 \%)$ \\
\hline
\end{tabular}

\section{Summary}

In this chapter, I provided a detailed analysis of the data and presented descriptive univariate statistics to show demographic characteristics of the faculty-respondents and their perceptions of student engagement in academically dishonest behaviors, academic 
integrity policies, institutional support, and self-plagiarism. I conducted bivariate analyses between each of the independent and dependent variables which permitted identification of factors that were related to perceptions and understanding. Specifically, gender was correlated with faculty perceptions of student academic dishonesty and selfplagiarism. Female faculty were more likely than their male counterparts to believe that undergraduate students regularly cheated on exams, wrongfully shared their work, plagiarized written assignments, and violated institutional integrity policies. Women were also more likely than men to believe that graduate students regularly cheated on exams and violated institutional policies as well as to believe that the failure to secure instructor-consent prior to recycling a paper and that recycling entire papers constituted self-plagiarism.

Whether or not faculty had tenure (or were tenure-track) or were non-tenured was correlated with perceptions of self-plagiarism and institutional support. Non-tenured faculty were more likely than tenured/tenure-track faculty to perceive that students who failed to obtain instructor-consent prior to recycling an assignment had self-plagiarized and that turning in previously submitted group work as an individual assignment constituted self-plagiarism. Moreover, non-tenured faculty were more likely than their tenured colleagues to perceive senior administrators, including their deans, as supportive and encouraging.

Additionally, whether courses were taught online or on campus was associated with faculty perceptions of academic misconduct. Online faculty were more likely than campus-based faculty to believe that plagiarism was commonplace among graduate students. 
Finally, I used hierarchical log linear analyses to examine the associations between the variables constituting the relevant dependent concepts. As significant associations existed between the variables, I rejected the three null hypotheses measuring the dependent variables. 


\section{CHAPTER V}

\section{CONCLUSION}

Chapter V summarizes the study and briefly discusses the data analyses.

Limitations and recommendations for future research are included as are policy issues and implications.

\section{Summary of the Study}

Much to the dismay of academicians, academic misconduct is perceived as a common occurrence among undergraduate students (Graham et al., 1994; Haines et al., 1986; McCabe \& Trevino, 1993; Whitley, 1998). As faculty often assume the responsibility of policing misconduct among students, their attitudes and perceptions warrant investigation. Therefore, the purpose of this descriptive study was to assess faculty perceptions regarding the frequency of academic dishonesty among students and faculty understanding of self-plagiarism, academic integrity policies, and institutional responses to policy violations.

The study was guided by three research questions: (a) how do university faculty perceive their institution's academic integrity policies; (b) how do university faculty perceive their institution's responses to policy violations; and (c) how do university faculty understand self-plagiarism? Accordingly, I tested the following hypotheses:

$\mathrm{H}_{1}$ : There is no relationship among the variables used to measure faculty perceptions of institutional academic integrity policies.

$\mathrm{H}_{2}$ : There is no relationship among the variables used to measure faculty perceptions of institutional responses to student engagement in academically dishonest behaviors. 
$\mathrm{H}_{3}$ : There is no relationship among the variables used to measure faculty understanding of self-plagiarism.

\section{Discussion of the Analyses}

As it is plausible that diverse faculty and those who chose not to participate in the study may have different perceptions of academic dishonesty, the following findings should be interpreted with caution.

\section{Research Question 1: How do faculty perceive their institution's academic integrity policies?}

The majority of the respondents rated understanding and support of the policies as well as policy effectiveness and the severity of the penalties for policy violations as moderate or high. Nearly $90 \%$ of the respondents indicated that institutional procedures were in place to deal with academic misconduct; however, of that group, only $68 \%$ indicated that the procedures were clear and easy to follow. Bivariate analyses revealed that faculty understanding of policies varied by the level of students taught. More specifically, faculty who taught undergraduate students were more likely than those teaching graduate students to understand academic integrity policies.

The corresponding hypothesis posited that there was no relationship among the variables used to measure perceptions of integrity policies. Hierarchical log linear analyses revealed several significant interactions:

1. Faculty with low understanding and low perceptions of policy efficacy were more likely to perceive the penalties as less severe.

2. Faculty with high perceptions of policy efficacy were more likely to perceive penalties for policy violations as severe. 
3. Faculty who perceived the policies as effective were more likely to support the policies as were faculty who perceived penalties as severe.

4. Faculty who understood the academic integrity policies were more likely to support them.

As there were multiple interactions among the variables, I rejected the null hypothesis of no association.

\section{Research Question 2: How do faculty perceive their institution's responses to policy violations?}

The vast majority of the faculty agreed or strongly agreed that the department chairs, deans, and administrators were supportive and encouraged faculty to report instances of academic dishonesty. More than half of the faculty had previously referred students accused of academic misconduct to the appropriate university administrator. Of those faculty who referred students, more than one-fourth were either unsatisfied or very unsatisfied with the result. Notwithstanding, nearly all of the faculty reported that they would report future incidents of policy violations.

The bivariate analyses revealed a relationship between faculty rank and perceptions of administrative support. Non-tenured faculty were significantly more likely than their tenured peers to perceive university administrators and deans as supportive. The corresponding hypothesis stated that there was no association among the variables used to measure perceptions of support, but the multiway frequency analyses indicated otherwise:

1. Faculty who perceived university administrators as supportive were more likely to perceive deans as well as department chairs as supportive. 
2. Those who perceived department chairs as supportive were also likely to perceive deans as supportive.

Therefore, I rejected the second null hypothesis.

\section{Research Question 3: How do faculty understand self-plagiarism?}

Most of the respondents believed that self-plagiarism was not clearly defined and asserted that faculty did not understand the concept. Nonetheless, they believed that faculty should teach students about self-plagiarism. Approximately one-third of the respondents believed that faculty should encourage students to reuse parts of previously graded papers for new assignments, and the majority of the faculty asserted that students who built on previous assignments could increase learning and that, by doing so, were using their time wisely. Notwithstanding, nearly three-fourths of the respondents claimed that students who reused part of previously written papers for new assignments could expect potential problems.

Overall, the faculty asserted that students who reused a part of a previous paper for a new assignment without citing the original, who reused group assignments for individual work, or who recycled a completed paper for a new assignment had selfplagiarized. Additionally, the majority of the respondents agreed that students who did not get the instructor's permission when double-dipping an assignment had selfplagiarized.

The bivariate analyses revealed that non-tenured faculty were more likely than tenured faculty to believe that students needed permission to double-dip assignments and that reusing group work as an individual assignment was self-plagiarism. Women were also more likely than men to believe that students needed permission to double-dip 
assignments and that students who recycled previously submitted papers, in their entirety, had self-plagiarized.

The final hypothesis stated that there was no association between the variables used to measure faculty understanding of self-plagiarism. Hierarchical log linear analyses revealed the following significant interactions:

1. Faculty who believed that self-plagiarism included recycling a completed paper for a new assignment were likely to believe that self-plagiarism also included reusing parts of group assignments.

2. Faculty who believed that self-plagiarism included recycling a completed paper for a new written assignment were also likely to believe that students needed permission to do so.

3. Faculty who believed that reusing group work for an individual assignment was inappropriate were more likely to believe that reusing part of a previously submitted paper, without citing the original, constituted self-plagiarism.

4. Faculty who agreed that reusing group work as an individual assignment was inappropriate were more likely to believe that students who failed to get permission to double-dip papers had self-plagiarized.

As there were multiple significant interactions, I rejected the null hypothesis.

There were several other noteworthy findings deserving of discussion. The analyses revealed that faculty perceptions of student engagement in academically dishonest behaviors as well as how faculty understood self-plagiarism varied by gender. Relative to men, women were significantly more likely to believe that undergraduate students plagiarize on written assignments, cheat on exams, wrongfully share their work, 
and violate institutional integrity policies with some degree of regularity. Female faculty were more likely than their colleagues to believe that graduate students regularly cheated on exams and undermined integrity policies. In addition, women were more likely than men to believe that students needed to obtain instructor-permission to avoid selfplagiarism and that self-plagiarism included recycling or double-dipping previously submitted papers.

Although the extant literature has extensively addressed the relationship between students' gender and academic dishonesty, the role of gender in faculty perceptions has been ignored. As such, there are no studies or theories available to explain these relationships. There is, however, literature examining the relationship between academic misconduct among students and gender. Ward and Beck (1990) suggested that female students were "socialized to obey rules, whereas the socialization of men ... [was] less insistent in this regard” (p. 333). All members of the professoriate were, at some point, students. Supposedly, they learned appropriate and inappropriate behaviors during their undergraduate and graduate education, respectively. If female students were taught to uphold the traditions of the academy and the male students were not, then it is possible that those same values were transferred to the professoriate. This would lend support to the study's findings that female faculty perceive higher levels of academic dishonesty.

Two other possible explanations for this phenomenon involve the maledomination of the professoriate and the perception of respect. Women aspiring to positions traditionally dominated by men may feel pressured to "act like men" by demonstrating tough and demanding personas (Stevens, 2013). The perception that such a demeanor is necessary for female faculty to be taken seriously by their colleagues may 
result in women considering all academic integrity violations, even the most minor and mundane, as serious offenses against the academy and, thus, could explain why women perceive higher rates of academic misconduct relative to men. Notwithstanding, female faculty may also believe that university students respect male professors more than female professors. The perceived lack of respect within the classroom environment, on course evaluations, or on individual assignments may contribute to female staff's increased perceptions of academic misconduct among their students.

The academic rank of faculty was also related to perceptions of self-plagiarism and institutional support. Non-tenured faculty were more likely than tenured/tenure-track faculty to believe that students who failed to secure permission to recycle their work or who submitted work that originated from a previously submitted group assignment had self-plagiarized. They were also significantly more likely than their peers to perceive university administrators and deans as supportive and encouraging in their efforts to combat student dishonesty.

Not surprisingly, the extant literature has also ignored the role of faculty rank in perceptions of academic misconduct. This study found that non-tenured faculty, relative to tenured-tenure track faculty, perceived higher rates of academic dishonesty among students. This may be the result of the perceived lack of job security afforded to nontenured faculty. In other words, non-tenured faculty may feel less secure about their positions and may, in turn, believe that strict adherence to institutional rules will provide them with increased job security and foster the impression that they not only follow the traditions of the academy, but they also regularly and consistently enforce academic integrity policies. An alternative explanation could be based upon a rationale involving 
tenure-track faculty, in particular, and the reasons that some faculty have reported for ignoring academic misconduct. Dealing with academic dishonesty is stressful, difficult, and time-consuming (Alschuler \& Blimling, 1995; Groark et al., 2001; Hughes \& McCabe, 2006; Keith-Spiegel et al., 1998; McCabe, 1993). Tenured/tenure track faculty may simply lack the time and desire to acknowledge misconduct because of their research, teaching, and service obligations. Consequently, they may ignore any unethical behaviors from students which would result in a perceived lower rate of student academic misconduct among tenured/tenure-track faculty.

Two other notable findings were that online faculty were significantly more likely than campus-based faculty to believe that graduate students plagiarized written assignments with some degree of regularity, and that faculty who taught undergraduate students were significantly more likely than those teaching graduate students to understand academic integrity policies. Much of the literature has shown that faculty perceive academic dishonesty as occurring more frequently within the online environment rather than the brick-and-mortar classroom (Grijalva et al., 2006; King et al., 2009). Kennedy and colleagues (2000) explored this idea, noting that the limited interaction between online students and faculty "breeds feelings of isolation as well as perceptions of inaccessibility and distance” (Robinson, 2013, p. 190), which, in turn, may reduce any trepidation associated with engaging in academic misconduct and the consequences thereof (Bailey \& Baily, 2011; Kennedy et al., 2000). Although the literature has limited its focus to the perceptions of academic dishonesty among undergraduates within the online environment, the same perceptions may be true for the 
graduate student population as there is no reason to believe that graduate students are not subjected to the same feelings of alienation and resulting temptation to cheat.

Additionally, faculty who taught undergraduate students were more likely than those teaching graduate students to understand academic integrity policies. The extant literature does not address this issue. Nonetheless, given the perception that undergraduates engage in academic misconduct much more frequently than graduate students, it is possible that undergraduate faculty simply have more experience in identifying academic dishonesty and implementing those policies in their classrooms.

Not to be overlooked, the findings revealed that approximately $20 \%$ of faculty believed that department chairs and deans neither encouraged nor supported faculty who chose to address, confront, and punish students accused of misconduct. In a similar vein, $25 \%$ of faculty perceived that their institutions' senior administrators were neither supportive nor encouraging. Faculty who do not feel supported by their institution's administrators may be reluctant to refer academically dishonest students to the appropriate administrators or pursue sanctions against those students, as necessary. In fact, both anecdotal evidence and the literature reveal that faculty sometimes feel attacked, rather than supported, by administrators responsible for disciplining students accused of academic misconduct (Spiegel et al., 1998; Williams \& Hosek, 2003).

\section{Limitations and Recommendations for Future Research}

In light of my findings, the limitations of this study should be addressed. As was expected, the most significant methodological limitation was the low response rate. Generally, faculty are poor survey respondents (Mitchell, 1998), and the study topic may have discouraged participation. The questionnaire was e-mailed to 1,000 full-time 
instructional faculty employed at six of the 12 institutions of higher education that comprise the Florida State University System. Two electronic follow-up reminders were sent at one-week intervals. Despite these efforts, only 218 surveys were completed, and a considerable amount of missing data required the listwise deletion of cases with missing variables (Allison, 2002). My efforts yielded a final sample size of 201 respondents, which greatly limit the generalizability of the findings. The next limitation was the lack of a definition of self-plagiarism within the survey instrument. The presence of a definition could have altered the respondents' perceptions regarding self-plagiarism as a form of academic dishonesty. Last, there were no theories available to explain how faculty perceive academic dishonesty. As such, the instant study only described the current perceptions of faculty and offered no predictors of the same.

Several of the limitations must be considered for future research. The lack of a universally accepted definition of academic misconduct remains problematic for faculty and staff responsible for disciplining students who violate academic integrity policies. Certainly, there are behaviors that are indubitably considered dishonest (i.e., copying from another student's exams, purchasing papers, and stealing exams); nevertheless, the appropriateness of other behaviors less commonly perceived as unethical (i.e., submitting one writing assignment for more than one course or collaborating on an assignment without permission) remain troublesome for some faculty (Bennett et al., 2011; Higbee \& Thomas, 2002). This is important as there are neither institutional nor industry standards on what student self-plagiarism, double-dipping, or recycling entails. Therefore, studies attempting to distinguish between the three may be worthwhile if a consensus is desired regarding which behaviors are or are not appropriate within the academy. 
Additional research should also include university administrators as well as students. University administrators are often involved in writing academic integrity policies and disciplining the students who violate those policies. Consequently, what they perceive as academic dishonesty warrants investigation. Research involving students' perceptions of faculty responses to academic dishonesty, on the other hand, may also reveal important relationships between faculty attitudes, responses, and student understanding of policies and appropriate behaviors.

As the study was limited by site selection and institutional type (i.e., using only public institutions of higher education within Florida), additional research must be conducted involving an assortment of institutions of higher education (i.e., community colleges, for-profit, and private institutions) that are, both, geographically and culturally diverse. A national sample might reveal geographical and cultural variations in the perceptions of behaviors traditionally considered as academically dishonest, and differences in perceptions of academic dishonesty and academic integrity policies among and within groups may be illuminated; the implication of both situations could be numerous.

Several of the findings also indicate a need for future research. A review of the literature revealed the assumption of faculty that online undergraduate students may be predisposed to engaging in academically dishonest behaviors (Grijalva et al., 2006; King et al., 2009). The current study, however, showed that perceptions of academic dishonesty varied only for online faculty and their perception of graduate students. Although the online faculty were no more likely than campus-based faculty to perceive high levels of academic dishonesty among undergraduate students, the perception of 
online faculty suggests that graduate student engagement in academic misconduct—at least in terms of plagiarism-may be increasing. As the extant literature focuses on the cheating behaviors of undergraduate students, additional research should be conducted with a larger sample to see if the differences between online and campus-based faculty perceptions remain as well as to examine the perceived and actual prevalence rates of academic dishonesty among graduate students.

Last, the multiway frequency analyses revealed significant interactions among the variables used to measure the three dependent concepts. Therefore, future research including more sophisticated analyses such as factor analysis may be warranted to determine the amount of variance attributed to each of the variables measuring faculty perceptions.

\section{Policy Issues and Implications}

Overall, faculty perceptions of academic dishonesty were not surprising. The respondents’ perceptions were similar to that of other faculty around the country. The faculty at Texas Tech University (TTU), for example, believed that plagiarism, inappropriately sharing group work, and cheating on exams was commonplace (DuPree \& Sattler, 2010). The majority of TTU faculty rated severity of penalties as low or medium whereas the majority of the Florida faulty in the current study rated the penalties as moderate or high. Both TTU faculty and the current study’s respondents rated understanding and support of the policies as medium/moderate or high. However, TTU faculty rated policy efficacy as low or medium while Florida faculty rated efficacy as moderate or high. Clearly, faculty assert that they understand and support policies; yet, 
their perceptions vary as they relate to the frequency of student engagement in academically dishonest behaviors, policy efficacy, and severity of penalties.

The instant study revealed that faculty perceptions of student engagement in academically dishonest behaviors as well as how faculty understand self-plagiarism varied by gender and academic rank. The fact that there are more female non-tenured faculty than male non-tenured faculty across the country (U.S. Department of Education, Institute of Education Sciences, National Center for Education Statistics, 2015) may provide insight into why the women and non-tenured faculty in the current study shared certain beliefs; put simply, these individuals may actually be one and the same. If women and non-tenured faculty possess greater understanding of misconduct and vigorously pursue academic integrity violations, then the students of said faculty would be expected to adhere to the traditional values and norms of the academy, thereby refraining from misconduct. The implication, in turn, is that students who are taught by men or tenured faculty may be more likely to engage in academically dishonest behaviors. Thus, attempts to resocialize men and tenured/tenure-track faculty to the traditions of the academy may be warranted.

The variations in the respondents' perceptions demonstrate the difficulty in aligning classroom policies and faculty-issued sanctions with institutional policies which, in turn, suggests that university administrators should focus on educating instructional staff about the various forms of academic dishonesty including, but not limited, to selfplagiarism. It is important for administrators to understand that graduate students aspiring to the professoriate as well as new and seasoned faculty may not have been exposed to the institution's academic integrity policies. Ignorance of such policies and 
available sanctions may adversely affect faculty response to academic dishonesty or may cause faculty to ignore incidents of misconduct altogether. Today's academic environment requires articulation of explicit definitions that acknowledge the subtle nuances and variations in acceptable behaviors and promotes the uniform and transparent application of penalties to the university community. Accordingly, institutions of higher education must review and revise their academic integrity policies, as appropriate. Moreover, although one would expect faculty to learn about academic integrity policies during new faculty orientation or periodic professional development events, as the faculty in the instant study noted, the faculty handbook is paramount in terms of teaching instructional staff about proscribed behaviors. Therefore, the faculty handbook should be modified to reflect any changes to institutional policies as this will indubitably enhance faculty understanding of academic misconduct and assist instructors in identifying academically dishonest behaviors.

The literature also supports the idea that faculty may feel attacked, rather than supported, by administrators responsible for disciplining students accused of academic misconduct (Spiegel et al., 1998; Williams \& Hosek, 2003). Therefore, university administrators must acknowledge that their action or perceived inaction may foster not only apathy among faculty but also the failure to respond, each of which may alter faculty perceptions.

Finally, continued reflection upon academic dishonesty within academy forced me to acknowledge that self-plagiarism is more problematic and controversial than this study revealed, in part, because of the variations in terminology used to describe undesirable behavior. Hence, the respondents' understanding of self-plagiarism warrants 
discussion. Similar to the faculty assessed by Bennett and colleagues (2011) and those in Halupa and Bolliger’s (2013) study, the respondents in the instant study struggled with self-plagiarism and asserted that the concept was not clearly defined. In fact, the vast majority of the respondents were unable to articulate a definition of the term or arrive at a consensus as to which behaviors constituted self-plagiarism. Notwithstanding, the faculty believed that they were responsible for teaching their students about the concept. The fact that most of the respondents concurred that building on previous assignments could increase the depth of learning and that students who incorporated previous assignments into new assignments were using their time wisely yet also asserted that recycling could lead to potential problems indicates that faculty may be troubled by the concept of self-plagiarism in and of itself. In fact, the members of my dissertation committee discussed the issue at length, suggesting that faculty may simply reject the idea that self-plagiarism is possible, particularly for students, as the term "plagiarism" involves "[t]he public misrepresentations of work as original, or any activity in which a person knowingly or unknowingly and for some form of gain, represents the work of another as his/her own” (Robinson-Zanartu \& Pena, 2005, p. 319). Faculty, on the other hand, may readily identify with and understand double-dipping-a concept describing an instance where "a student submits a whole paper or a substantial portion of a paper to fulfill a course requirement, even though that paper had earlier been submitted to satisfy the requirements for another course taught by a different professor” (U.S. Department of Health \& Human Services, 2011). If the premise that faculty deny the existence of selfplagiarism rings true, and faculty concur that double-dipping is actually the problem at hand, then the findings of the instant study are understandable, if not expected, as faculty 
may simply view “recycling one’s work ... [as] qualitatively different from claiming credit for someone else's work” (Bennett et al., 2011, p. 33).

In sum, this dissertation added to the extant literature by examining faculty perceptions of academic dishonesty and academic integrity policies. The study demonstrated the need for consistency in definitions and policies as well as for practitioners and educators to unite in their efforts to develop policies that address both industry and educational standards. Furthermore, it illustrated the importance of considering faculty perceptions when developing policies and deterrent strategies particularly as the "ability to alter the environment in which cheating takes place will be determined by our understanding of how... [faculty] perceive cheating and its seriousness” (Roberts \& Rabinowitz, 1992, p. 189). Hence, future research efforts must continue to extend this literature. 


\section{REFERENCES}

Aaron, R. M., \& George, R. T. (1994). Administrator perceptions of student academic dishonesty. NASPA Journal, 31(2), 83-91.

Alschuler, A. S., \& Blimling, G. S. (1995). Curbing epidemic cheating through systemic change. College Teaching, 43(4), 123-125.

American Psychological Association. (2010). Publication Manual of the American Psychological Association (6th ed.). Washington DC: Author.

Anderman, E. M., Griesinger, T., \& Westerfield, G. (1998). Motivation and cheating during early adolescence. Journal of Educational Psychology, 90(1), 84-93.

Ary, D., Jacobs, L. C., \& Sorenson, C. (2010). Introduction to research in education (8th ed.). Belmont, CA: Wadsworth.

Babbie, E. R. (1990). Survey research methods (2nd ed.). Belmont, CA: Wadsworth.

Bachmann, D. P., Elfrink, J., \& Vazzana, G. (2000). E-mail vs. snail mail face off in rematch. Marketing Research, 11(4), 10-15.

Bailey, W. C., \& Bailey, S. S. (2011). Do online and lecture students view cheating differently? Review of Business Research, 11(5), 33-45.

Baird, J. S. (1980). Current trends in college cheating. Psychology in the Schools, 17(4), 515-522.

Bennett, K. K., Behrendt, L. S., \& Boothby, J. L. (2011). Instructor perceptions of plagiarism: Are we finding common ground? Teaching of Psychology, 38(1), 2935. doi:10.1177/009862831039085

Bennington, A. J., \& Singh, H. (2013). Faculty expectations of administration: Predictors of intention to report student plagiarism. Academy of Educational Leadership Journal, 17(4), 63-76.

Best, S. J., \& Krueger, K. (2002). New approaches to assessing opinion: The prospects for electronic mail surveys. International Journal of Public Opinion Research, 14(1), 73-92.

Bourque, L. B., \& Fielder, E. P. (2003). The survey kit 2: How to conduct selfadministered and mail surveys (2nd ed.). Thousand Oaks, CA: Sage.

Cizek, G. J. (2003). Detecting and preventing classroom cheating: Promoting integrity in assessment. Thousand Oaks, CA: Corwin. 
Coalter, T., Lim, C. L., \& Wanorie, T. (2007). Factors that influence faculty actions: A study on faculty responses to academic dishonesty. International Journal for the Scholarship of Teaching and Learning, 1(1), 1-19.

Comas-Forgas, R., \& Sureda-Negre, J. (2010). Academic plagiarism: Explanatory factors from students' perspective. Journal of Academic Ethics, 8, 217-232.

Conway-Klaassen, J. M., \& Keil, D. (2010). Discouraging academic dishonesty in online courses. Clinical Laboratory Science, 23(4), 194-200.

Coren, A. (2011). Turning a blind eye: Faculty who ignore student cheating. Journal of Academic Ethics, 9, 291-305. doi:10.1007/s10805-011-9147-y

Coston, C. T., \& Jenks, D. A. (1998). Exploring academic dishonesty among undergraduate criminal justice majors: A research note. American Journal of Criminal Justice, 22, 235-248. doi:10.1007/BF02887259

Creswell, J. W. (2003). Research Design: Qualitative, quantitative, and mixed methods approaches (2nd ed.). Thousand Oaks, CA: Sage.

Davis, K. (1992). Student cheatingt: A defensive essay. The English Journal, 81(6), 7274. doi:10.2307/820139

Diekhoff, G. M., LaBeff, E. E., Clark, R. E., Williams, L. E., Francis, B., \& Haines, V. J. (1996). College cheating: Ten years later. Research in Higher Education, 37(4), 487-502.

Dufresne, R. L. (2004). An action learning perspective on effective implementation of academic honor codes. Group \& Organization Management, 29(2), 201-218. doi:10.1177/1059601103261472

DuPree, D., \& Sattler, S. (2010). Texas Tech University McCabe academic integrity survey report. Texas Tech University. Lubbock: Texas Tech University Ethics Center. Retrieved from http://www.depts.ttu.edu/provost/qep/20052010/docs/McCabe_Academic_Integrity_Report_Cover.pdf

Eskridge, C., \& Ames, G. A. (1993). Attitudes about cheating and self-reported cheating behaviors of criminal justice and noncriminal justice majors: A research note. Journal of Criminal Justice Education, 4, 65-78. doi:10.1080/10511259300082771

Franklyn-Stokes, A., \& Newstead, S. E. (1995). Undergraduate cheating: Who does what and why. Studies in Higher Education, 20(2), 159-172.

Gehring, D., \& Pavela, G. (1994). Issues and perspectives on academic integrity (2nd ed.). Washington, DC: National Association of Student Personnel Administrators. 
Graham, M. A., Monday, J., O'Brien, K., \& Steffen, S. (1994). Cheating at small colleges: An examination of student and faculty attitudes and behaviors. Journal of College Student Development, 35, 255-260.

Grijalva, T. C., Nowell, C., \& Kerkvliet, J. (2006). Academic dishonesty and online courses. College Student Journal, 40(1), 180-185.

Groark, M., Oblinger, D., \& Choa, M. (2001). Term paper mills, anti-plagiarism tools, and academic integrity. Educause, 36(5), 40-48.

Haines, V. J., Diekhoff, G. M., LaBeff, E. E., \& Clark, R. E. (1986). College cheating: Immaturity, lack of commitment, and the neutralizing attitude. Research in Higher Education, 25(4), 342-354.

Hall, T., \& Kuh, G. (1998). Honor among students: Academic integrity and honor codes at state-assisted universities. NASPA Journal, 36(1), 2-18.

Halupa, C., \& Bolliger, D. (2013). Faculty perceptions of student self plagiarism: An exploratory multi-university study. Journal of Academic Ethics, 11, 297-310. doi:10.1007s/10805-013-9195-6

Hensley, L. (2013). To cheat or not to cheat: A review with implications for practice. The Community College Enterprise, Fall, 22-34.

Higbee, J. L., \& Thomas, P. V. (2002). Student and faculty perceptions of behaviors that constitute cheating. NASPA Journal, 40(1), 39-52.

Houston, J. P. (1977). Cheating behavior, anticipated success-failure, confidence and test importance. Journal of Educational Psychology, 69(1), 55-60.

Houston, J. P. (1983). College classroom cheating, threat, sex, and prior performance. College Student Journal, 17(3), 229-235.

Houston, J. P. (1986). Classroom answer copying: Roles of acquaintanceship and free vs. assigned seating. Journal of Educational Psychology, 78(3), 230-232.

Hughes, J. M., \& McCabe, D. L. (2006). Understanding academic misconduct. The Canadian Journal of Higher Education, 36(1), 49-63.

Hutton, P. A. (2006). Understanding student cheating and what educators can do about it. College Teaching, 54(1), 171-176.

International Center for Academic Integrity. (2012). Fundamental Values Project. Retrieved from International Center for Academic Integrity: http://www.academicintegrity.org/icai/resources-2.php 
Keith-Spiegel, P., Tabachnick, B. G., Whitley, B. E., \& Washburn, J. (1998). Why professors ignore cheating: Opinions of a national sample of psychology instructors. Ethics \& Behavior, 8(3), 215-227.

Kelley, K. B., \& Bonner, K. (2005). Digital text, distance education and academic dishonesty: Faculty and administrator perceptions and responses. The Journal of Asynchronous Learning Networks, 9(1), 43-52.

Kennedy, K., Nowak, S., Raghuraman, R., Thomas, J., \& David, S. F. (2000). Academic dishonesty and distance learning: Student and faculty views. College Student Journal, 34, 309-314.

King, C. G., Guyette, R. W., \& Piotrowski, C. (2009). Online exams and cheating: An empirical analysis of business students' view. The Journal of Educators Online, 6(1), 1-11. Retrieved from http://www.thejeo.com/Archives/Volume6Number1/Kingetalpaper.pdf

Kleiner, C., \& Lord, M. (1999, November 2). The cheating game: Everyone's doing it,' from grade school to graduate school. U.S. News \& World Report, pp. 55-66.

Kumar, R. (2014). Research methodology: A step-by-step guide for beginners (4th ed.). Los Angeles, CA: Sage.

Lambert, E. G., \& Hogan, N. L. (2004). Academic dishonesty among criminal justice majors: A research note. American Journal of Criminal Justice, 29(1), 1-20.

Lanza-Kaduce, L., \& Klug, M. (1986). Learning to cheat: The interaction of moraldevelopment and social learning theories. Deviant Behavior, 7(3), 243-259.

Lester, M. C., \& Diekhoff, G. M. (2002). A comparison of traditional and internet cheaters. Journal of College Student Development, 43(5), 2-7.

Maramark, S., \& Maline, M. B. (1993). American dishonesty among college students. Washington, D. C.: Office of Research United States Department of Education.

Marcus, S., \& Beck, S. (2011). Faculty perceptions of plagiarism at Queensborough Community College. Community \& Junior College Libraries, 17(2), 63-73. doi:http://dx.doi.org/10.1080/02763915.2011.591709

Mathur, R., \& Offenbach, S. I. (2001). Preliminary observations on faculty and graduate student perceptions of questionable research conduct. Investigating Research Integrity (pp. 35-40). Bethesda, MD: Office of Research Integrity, Department of Health and Human Services.

Mavis, B. E., \& Brocato, J. J. (1998). Postal surveys versus electronic mail surveys: The tortoise and the hare revisisted. Evaluation and the Health Professions, 21(3), 395-408. 
McCabe, D. L. (1993). Faculty responses to academic dishonesty: The influence of student honor codes. Research in Higher Edcuation, 34(5), 647-658.

McCabe, D. L. (1997). Classroom cheating among natural science and engineering majors. Science and Engineering Ethics, 3(4), 433-445. doi:DOI:10.1007/s11948997-0046-y

McCabe, D. L., \& Bowers, W. J. (1996). The relationship between student cheating and college fraternity or sorority membership. NASPA Journal, 33, 280-291.

McCabe, D. L., \& Trevino, L. K. (1993). Academic dishonesty: Honor codes and other contextual influences. The Journal of Higher Education, 64(5), 522-538.

McCabe, D. L., \& Trevino, L. K. (1996). What we know about cheating in college: Longitudinal trends and recent developments. Change, 28, 23-33.

McCabe, D. L., \& Trevino, L. K. (1997). Individual and contextual influences on academic dishonesty: A multicampus investigation. Research in Higher Education, 38, 379-396.

Mertens, D. M. (1998). Research methods in education and psychology: Integrating diversity with quantitative and qualitative approaches. Thousand Oaks, CA: Sage.

Michaels, J. W., \& Miethe, T. D. (1989). Applying theories of deviance to academic cheating. Social Science Quarterly, 70, 870-885.

Mitchell, V. W. (1998). Improving mail survey responses from UK academics: Some empirical findings. Assessment \& Evaluation in Higher Education, 23(1), 59-71.

O'Rourke, J., Barnes, J., Deaton, A., Fulks, K., Ryan, K., \& Rettinger, D. A. (2010). Imitation is the sincerest form of cheating: The influence of direct knowledge and attitudes on academic dishonesty. Ethics \& Behavior, 20(1), 47-64.

Park, C. (2003). In other (people's) words: Plagiarism by university students--literature and lessons. Assessment \& Evaluation in Higher Education, 28(5), 471-488. doi:10.1080/0260293032000120352

Pincus, H. S., \& Schmelkin, L. P. (2003). Faculty perceptions of academic dishonesty: A multidimension scaling analysis. The Journal of Higher Education, 74, 196-209.

Puka, B. (2005). Student cheating. Liberal Education, 32-35.

recycle. (2016). Retrieved from Dictionary.com: http://www.dictionary.com/browse/recycle

Rettinger, D. A., \& Kramer, Y. (2009). Situational and personal causes of student cheating. Research in Higher Education, 50, 293-313. 
Roberts, D., \& Rabinowitz, W. (1992). An investigation of student perceptions of cheating in academic situations. Review of Higher Education, 15(2), 179-190.

Robinson, C. V. (2013). Academic dishonesty: A guide for digital instructors. In M. S. Plakhotnik, \& S. M. Nielsen (Ed.), 12th Annual South Florida Education Research Conference (pp. 189-194). Miami: Florida International University. Retrieved from http://education.fiu.edu/research_conference/

Robinson-Zanartu, C., \& Pena, E. D. (2005). Academic crime and punishment: Faculty members' perceptions of and responses to plagiarism. School Psychology Quarterly, 20(3), 318-337.

Roig, M., \& DeTommaso, L. (1995). Are cheating and plagiarism related to procrastination? Psychological Reports, 77, 691-698.

Rutgers, The State University of New Jersey. (2014). Donald McCabe. Retrieved from Rutgers Business School: http://business.rutgers.edu/tags/332

Schmelkin, L. P., Gilbert, K., Spencer, K. J., Pincus, H. S., \& Silva, R. (2008). A multidimensional scaling of college students' perceptions of academic dishonesty. The Journal of Higher Education, 79(5), 587-607.

Shannon, D. M., \& Bradshaw, C. C. (2002). A comparison of response rate, response time, and costs of mail and electronic surveys. The Journal of Experimental Education, 70(2), 179-192.

Sheehan, K. B. (2006). E-mail survey response rates: A review. Journal of ComputerMediated Communication, 6(2). doi:10.1111/j.1083-6101.2001.tb00117.x

Sheehan, K. B., \& Hoy, M. G. (1999). Using e-mail to survey Internet users in the United States: Methodology and assessment. Journal of Computer Mediated Communication, 4(3). doi:10.1111/j.1083-6101.199.tb00101.x

Sheehan, K. B., \& McMillan, S. J. (1999). Response variation in e-mail surveys: An exploration. Journal of Advertising Research, 39(4), 45-54.

Sierles, F. S., Kushner, B. D., \& Krause, P. B. (1988). A controlled experiment with a medical school student honor system. Journal of Medical Education, 63(9), 705712.

Simkin, M. G., \& McLeod, A. (2010). Why do college students cheat? Journal of Business Ethics, 94(3), 441-453.

Sproull, L. S. (1986). Using electronic mail for data collection in organizational research. Academy of Management Journal, 29(1), 156-169. 
Staats, S., Hupp, J. M., Wallace, H., \& Gresley, J. (2009). Heroes don't cheat: An examination of academic dishonesty and students' views on why professors don't report cheating. Ethics \& Behavior, 19(3), 171-183.

Stannard, C. I., \& Bowers, W. J. (1970). The college fraternity as an opportunity structure for meeting academic demands. Social Problems, 17(3), 371-390.

Stevens, M. (2013, September 13). Women 'feel pressure to act like men at work', survey finds. Retrieved from CIPD:

http://www.cipd.co.uk/pm/peoplemanagement/b/weblog/archive/2013/09/13/wom en-feel-pressure-to-act-like-men-at-work-survey-

finds.aspx?utm_medium=email\&utm_source=cipd\&utm_campaign=pmdaily\&ut m_content=130913_news_2

Sutton, E. M., \& Huba, M. E. (1995). Undergraduate student perceptions of academic dishonesty as a function of ethnicity and religious participation. NASPA Journal, 33, 19-34.

Sykes, G. M., \& Matza, D. (1957). Techniques of neutralization: A theory of delinquency. American Sociological Review, 22, 664-670.

Sykes, G. M., \& Matza, D. (1994). Techniques of neutralization. In J. E. Jacoby, Classics of Criminology (pp. 221-224). Prospect Heights, IL: Waveland Press.

Tom, G., \& Borin, N. (1988). Cheating in academe. Journal of Education for Business, 63(4), 153-157.

U.S. Department of Education, Institute of Education Sciences, National Center for Education Statistics. (2015). Digest of education statistics: 2013. (NCES 2015011). Retrieved from https://nces.ed.gov/programs/digest/d13/index.asp

U.S. Department of Health \& Human Services. (2011, June 6). Academic Self-plagiarism (Double-dipping). Retrieved from The Office of Research Integrity: http://ori.hhs.gov/plagiarism-15

Vogt, W. P. (2005). Dictionary of statistics \& methodology: A nontechnical guide for the social sciences. Thousand Oaks, CA: Sage.

Volpe, R., Davidson, L., \& Bell, M. C. (2008). Faculty attitudes and behaviors concerning student cheating. College Student Journal, 42(1), 164-175.

Vowell, P. R., \& Chen, J. (2004). Predicting academic misconduct: A comparative test of four sociological explanations. Sociological Inquiry, 74(2), 226-249.

Walker, J. (2010). Measuring plagiarism: Researching what students do, not what they say they do. Studies In Higher Education, 35(1), 41-59.

doi:10.1080/03075070902912994 
Ward, D. A., \& Beck, W. L. (1990). Gender and dishonesty. The Journal of Social Psychology, 130, 333-339.

Weible, R., \& Wallace, J. (1998). The imact of the Internet on data collection. Marketing Research, 10(3), 19-23.

Whitley, B. E. (1998). Factors associated with cheating among college students: A review. Research in Higher Education, 39(3), 235-274.

Williams, A. E., \& Janosik, S. M. (2007). An examination of academic dishonesty among sorority and nonsorority women. Journal of College Student Development, 48(6), 706-714. doi:10.1353/csd.2007.0066

Williams, M. S., \& Hosek, W. R. (2003). Strategies for reducing academic dishonesty. Journal of Legal Studies Education, 21, 87-92.

Winfree, Jr., L. T., Backstrom, T. V., \& Mays, G. L. (1994). Social learning theory, selfreported delinquency, and youth gangs: A new twist on a general theory of crime and delinquency. Youth and Society, 26(2), 147-177.

Yardley, J., Rodriguez, M. D., Bates, S., \& Nelson, J. (2009). True confessions?:

Alumni's retrospective reports on undergraduate cheating behaviors. Ethics \& Behavior, 19(1), 1-14. 
APPENDICES 


\title{
Appendix A - Online Adult Consent Form
}

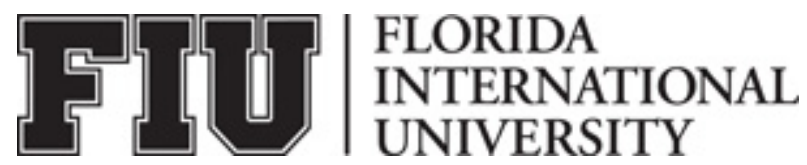

\author{
ADULT ONLINE CONSENT TO PARTICIPATE IN A RESEARCH STUDY \\ FACULTY PERCEPTIONS OF INSTITUTIONAL INTEGRITY POLICIES AND \\ STUDENT ACADEMIC DISHONESTY
}

\section{PURPOSE OF THE STUDY}

You are being asked to be in a research study. The purpose of this study is to assess faculty perceptions of academic integrity including but not limited to identifying the types of behaviors construed as academic dishonesty, the severity of those behaviors, and determining what factors, if any, affect faculty responses to the same.

\section{NUMBER OF STUDY PARTICIPANTS}

If you decide to be in this study, you will be one of 930 people in this research study.

\section{DURATION OF THE STUDY}

Your participation will require approximately 30 minutes of your time.

\section{PROCEDURES}

If you agree to be in the study, we will ask you to do the following things:

1. Complete an electronic mail (e-mail) survey.

\section{RISKS AND/OR DISCOMFORTS}

The following risks may be associated with your participation in this study: There are no known risks for your participation in the study.

\section{BENEFITS}

The following benefits may be associated with your participation in this study: Assisting the investigator in assessing faculty perceptions of academic integrity policies and student academic dishonesty. There are no direct benefits to you for your participation.

\section{ALTERNATIVES}

There are no known alternatives available to you other than not taking part in this study. However, any significant new findings developed during the course of the research which may relate to your willingness to continue participation will be provided to you.

\section{CONFIDENTIALITY}

The records of this study will be kept private and will be protected to the fullest extent provided by law. In any sort of report we might publish, we will not include any information that will make it possible to identify a subject. Research records will be 
stored securely and only the researcher team will have access to the records. However, your records may be reviewed for audit purposes by authorized University or other agents who will be bound by the same provisions of confidentiality.

Although, IP addresses will not be recorded, e-mail addresses will be collected to avoid multiple submissions. E-mail addresses will be stored electronically within a password protected folder stored on a password protected computer. A hard copy of the e-mail list will be stored in a locked filing cabinet in a locked office. One the date collection period has ended, a copy of the results will be forwarded to those individuals who initially requested the same, and the e-mail lists will be destroyed.

\section{COMPENSATION \& COSTS}

You will not receive any payment. You will not be responsible for any costs to participate in this study.

\section{RIGHT TO DECLINE OR WITHDRAW}

Your participation in this study is voluntary. You are free to participate in the study or withdraw your consent at any time during the study. Your withdrawal or lack of participation will not affect any benefits to which you are otherwise entitled. The investigator reserves the right to remove you without your consent at such time that they feel it is in the best interest.

\section{RESEARCHER CONTACT INFORMATION}

If you have any questions about the purpose, procedures, or any other issues relating to this research study you may contact Carleen Vincent-Robinson at Florida International University, 954.549.6279, cvinc001@fiu.edu.

\section{IRB CONTACT INFORMATION}

If you would like to talk with someone about your rights of being a subject in this research study or about ethical issues with this research study, you may contact the FIU Office of Research Integrity by phone at 305-348-2494 or by email at ori@fiu.edu.

\section{PARTICIPANT AGREEMENT}

I have read the information in this consent form and agree to participate in this study. I have had a chance to ask any questions I have about this study, and they have been answered for me. By clicking on the "consent to participate” button below I am providing my informed consent.

(Insert Consent to Participate Button Here on the Website) 


\section{Appendix B - Academic Integrity Faculty Survey}

\section{Academic Integrity Faculty Survey}

\section{PLEASE READ AND COMPLETE THIS SECTION BEFORE STARTING THE SURVEY}

For the protection of every faculty member completing this survey, we would like to confirm that you have read the e-mail you were sent describing the purpose of this Academic Integrity survey, that you wish to voluntarily participate, and that you are 18 years of age or older. Please affirm these points by checking the following "I Agree" box and then you may proceed to complete the survey.

$$
\text { I Agree }\ulcorner
$$

If you have any concerns or questions about the survey, you may contact Carleen Vincent-Robinson or you may contact the IRB Coordinator at Florida International University at: Florida International University, Institutional Review Board for the Protection of Human Subjects, Office of Research Integrity, MARC 270, Miami, FL 33199, by telephone at 305.348.8311.

\section{Section I: Academic Environment}

Welcome. Thank you for willingness to participate in this multi-university research project. Please read the questions below carefully and choose the answer that most closely matches your opinion or perception.

\section{Section I: Academic Environment}

I would like to ask you questions about the academic environment at your institution. Please rate (Low, Moderate, or High) the academic environment at your institution by checking one response for each question.

Q1. As a faculty member, I would rate ...

\begin{tabular}{|l|l|l|l|}
\hline & Low & Moderate & High \\
\hline (Q1a) ... the severity of penalties for cheating at & & & \\
my institution as & & & \\
\hline (Q1b) ... the average student's understanding of & & & \\
University policies concerning cheating as & & & \\
\hline $\begin{array}{l}\text { (Q1c) ... the faculty's understanding of these } \\
\text { policies as }\end{array}$ & & & \\
\hline (Q1d) ... student support of these policies as & & & \\
\hline (Q1e) ... faculty support of these policies as & & & \\
\hline
\end{tabular}


(Q1f) ... the effectiveness of these policies as

Q2. Please indicate your level of agreement (Strongly Disagree, Disagree, Agree, or Strongly Agree) with the following statements by checking one response for each question.

\begin{tabular}{|l|l|l|l|l|}
\hline & $\begin{array}{l}\text { Strongly } \\
\text { Disagree }\end{array}$ & Disagree & Agree & $\begin{array}{c}\text { Strongly } \\
\text { Agree }\end{array}$ \\
\hline $\begin{array}{l}\text { (Q2a) Cheating is a serious problem at } \\
\text { my institution. }\end{array}$ & & & & \\
\hline $\begin{array}{l}\text { (Q2b) Faculty members are vigilant in } \\
\text { discovering and reporting incidents of } \\
\text { academic dishonesty }\end{array}$ & & & & \\
\hline $\begin{array}{l}\text { (Q2c) Department chairs are supportive } \\
\text { of and encourage faculty to report } \\
\text { incidents of academic dishonesty }\end{array}$ & & & & \\
\hline $\begin{array}{l}\text { (Q2d) Deans are supportive of and } \\
\text { encourage faculty to report incidents of } \\
\text { academic dishonesty }\end{array}$ & & & & \\
\hline $\begin{array}{l}\text { (Q2e) Senior administrators are } \\
\text { supportive of and encourage faculty to } \\
\text { report incidents of academic dishonesty }\end{array}$ & & & & \\
\hline
\end{tabular}

Q3. Please note the primary sources from which you have learned about the academic integrity policies at your institution. (Check all that apply.)

Faculty orientation program

Faculty handbook

_ Department chair

_ Other faculty

_ Deans or other administrators

_ Students

_ University catalog

_ Publicized results of judicial hearings

_ Campus website

_ I have never been informed about campus policies concerning student cheating

_ Other

Q4. Please indicate your level of agreement (Never, Seldom, Often, Very Often) with the following statement by checking one response for each question.

How frequently do you think undergraduate students at your institution engage in the following behaviors? 


\begin{tabular}{|l|l|l|l|l|}
\hline (Q4a) Plagiarism on written assignments & Never & Seldom & Often & $\begin{array}{c}\text { Very } \\
\text { Often }\end{array}$ \\
\hline $\begin{array}{l}\text { (Q4b) Students inappropriately sharing } \\
\text { work in group assignments }\end{array}$ & Never & Seldom & Often & $\begin{array}{c}\text { Very } \\
\text { Often }\end{array}$ \\
\hline (Q4c) Cheating during tests or examinations & Never & Seldom & Often & $\begin{array}{c}\text { Very } \\
\text { Often }\end{array}$ \\
\hline $\begin{array}{l}\text { (Q4d) Students violating institutional } \\
\text { academic misconduct policies }\end{array}$ & & & & \\
\hline
\end{tabular}

Q5. Please indicate your level of agreement (Never, Seldom, Often, Very Often) with the following statement by checking one response for each question.

How frequently do you think graduate students at your institution engage in the following behaviors?

\begin{tabular}{|l|l|l|l|l|}
\hline (Q5a) Plagiarism on written assignments & Never & Seldom & Often & $\begin{array}{c}\text { Very } \\
\text { Often }\end{array}$ \\
\hline $\begin{array}{l}\text { (Q5b) Students inappropriately sharing } \\
\text { work in group assignments }\end{array}$ & Never & Seldom & Often & $\begin{array}{c}\text { Very } \\
\text { Often }\end{array}$ \\
\hline (Q5c) Cheating during tests or examinations & Never & Seldom & Often & $\begin{array}{c}\text { Very } \\
\text { Often }\end{array}$ \\
\hline $\begin{array}{l}\text { (Q5d) Students violating institutional } \\
\text { academic misconduct policies }\end{array}$ & & & & \\
\hline
\end{tabular}

Q6. If you were convinced that a student had cheated on a major test or assignment in your course, what would be your most likely reaction? (Check all that apply.)

_ Reprimand/warn the student

_ Require student to retake exam/resubmit assignment

_ Lower the student's grade

_ _ Fail the student on the test/assignment

_ Fail the student for the course

_ Report student to an administrator

_ Do nothing

_ Other

Q7. Have you ever ignored a suspected incident of cheating in one of your courses for any reason?

Yes
— No

Q8. If you answered "yes” to Question 7, please answer. Otherwise, proceed to Question 9. 
Did any of the following factors influence your decision? (Check all that apply.)

_ _ Lacked evidence/proof

_ Lack of support from administration

_ Didn't want to deal with bureaucracy

_ Cheating was trivial/not serious

_ Student will ultimately suffer

— Feared litigation

_ Too busy with other work responsibilities

_ Other

Q9. Is there an established procedure for faculty to report student involvement in academic misconduct?

Yes
— No
_ I don't know

Q10. If you answered "yes” to Question 9, please answer. Otherwise, proceed to Question 11.

If so, is the procedure clear and easy to follow?

Y Yes
— No
— I don't know

Q11. Have you ever referred a suspected case of cheating to your Chair, a Dean, or administrator?

- Yes

- No

Q12. If you answered “yes” to Question 11, please answer. Otherwise, proceed to Question 13.

How satisfied were you with the way the case(s) were handled?

_ Very unsatisfied

_ Unsatisfied

- Satisfied

— Very Satisfied 
Q13. Will you report future instances of academic misconduct to the appropriate Chair, dean, or other administrator?

Yes
— No
I I don't know

\section{Section II: Specific Behaviors}

Students and faculty often have differing views regarding what behaviors are appropriate. I would like to ask you some questions about specific behaviors that you might consider cheating. Please mark one response for each question.

Q14. Please mark how often (Never, Once, or More Than Once) you have observed or become aware of a student in your class engaging in any of the following behaviors during the last three years. Check one response for each question.

\begin{tabular}{|l|l|l|l|l|}
\hline & Never & Once & $\begin{array}{c}\text { Two or } \\
\text { More } \\
\text { Times }\end{array}$ & NA \\
\hline $\begin{array}{l}\text { Fabricating or falsifying a } \\
\text { bibliography. }\end{array}$ & & & & \\
\hline $\begin{array}{l}\text { Working on an assignment with } \\
\text { others when the instructor asked } \\
\text { for individual work. }\end{array}$ & & & & \\
\hline $\begin{array}{l}\text { Getting questions or answers } \\
\text { from someone who has already } \\
\text { taken a test. }\end{array}$ & & & & \\
\hline $\begin{array}{l}\text { Helping someone else cheat on a } \\
\text { test. }\end{array}$ & & & & \\
\hline $\begin{array}{l}\text { Fabricating or falsifying lab } \\
\text { data. }\end{array}$ & & & & \\
\hline $\begin{array}{l}\text { Fabricating or falsifying } \\
\text { research data. }\end{array}$ & & & & \\
\hline $\begin{array}{l}\text { Copying from another student } \\
\text { during a test with his or her } \\
\text { knowledge. }\end{array}$ & & & & \\
\hline $\begin{array}{l}\text { Copying from another student } \\
\text { during a test without his or her } \\
\text { knowledge }\end{array}$ & & & & \\
\hline $\begin{array}{l}\text { Using digital technology (such } \\
\text { as text messaging) to get } \\
\text { unpermitted help from someone } \\
\text { during a test or examination. }\end{array}$ & & & & \\
\hline
\end{tabular}




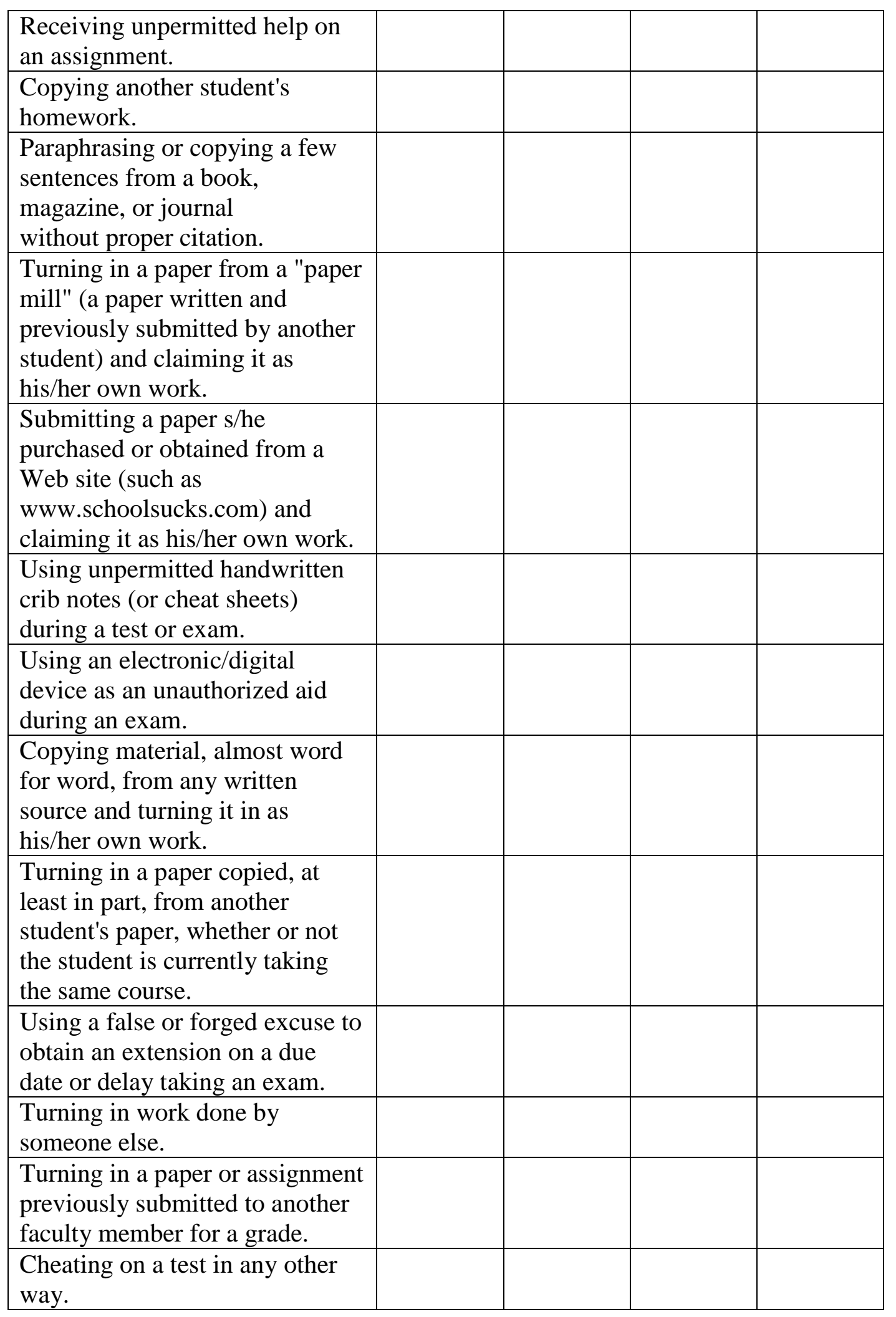


Q15. Please indicate the level seriousness (Not Cheating, Trivial Cheating, Moderate Cheating, or Serious Cheating) of each type of behavior. Check one response for each question.

\begin{tabular}{|l|l|l|l|l|}
\hline & $\begin{array}{c}\text { Not } \\
\text { cheating }\end{array}$ & $\begin{array}{c}\text { Trivial } \\
\text { Cheating }\end{array}$ & $\begin{array}{c}\text { Moderate } \\
\text { Cheating }\end{array}$ & $\begin{array}{c}\text { Serious } \\
\text { Cheating }\end{array}$ \\
\hline $\begin{array}{l}\text { Fabricating or falsifying a } \\
\text { bibliography. }\end{array}$ & & & & \\
\hline $\begin{array}{l}\text { Working on an assignment with } \\
\text { others when the instructor asked } \\
\text { for individual work. }\end{array}$ & & & & \\
\hline $\begin{array}{l}\text { Getting questions or answers } \\
\text { from someone who has already } \\
\text { taken a test. }\end{array}$ & & & & \\
\hline $\begin{array}{l}\text { Helping someone else cheat on a } \\
\text { test. }\end{array}$ & & & & \\
\hline $\begin{array}{l}\text { Fabricating or falsifying lab } \\
\text { data. }\end{array}$ & & & & \\
\hline $\begin{array}{l}\text { Fabricating or falsifying } \\
\text { research data. }\end{array}$ & & & & \\
\hline $\begin{array}{l}\text { Copying from another student } \\
\text { during a test with his or her } \\
\text { knowledge. }\end{array}$ & & & & \\
\hline $\begin{array}{l}\text { Copying from another student } \\
\text { during a test without his or her } \\
\text { knowledge }\end{array}$ & & & & \\
\hline $\begin{array}{l}\text { Using digital technology (such } \\
\text { as text messaging) to get } \\
\text { unpermitted help from someone } \\
\text { during a test or examination. }\end{array}$ & & & & \\
\hline $\begin{array}{l}\text { Receiving unpermitted help on } \\
\text { an assignment. }\end{array}$ & & & & \\
\hline $\begin{array}{l}\text { Copying another student's } \\
\text { homework. }\end{array}$ & & & & \\
\hline $\begin{array}{l}\text { Paraphrasing or copying a few } \\
\text { sentences from a book, } \\
\text { magazine, or journal } \\
\text { without proper citation. }\end{array}$ & & & & \\
\hline $\begin{array}{l}\text { Turning in a paper from a "paper } \\
\text { mill" (a paper written and } \\
\text { previously submitted by another } \\
\text { student) and claiming it as } \\
\text { his/her own work. }\end{array}$ & & & & \\
\hline $\begin{array}{l}\text { Submitting a paper s/he } \\
\text { purchased or obtained from a }\end{array}$ & & & & \\
\hline
\end{tabular}




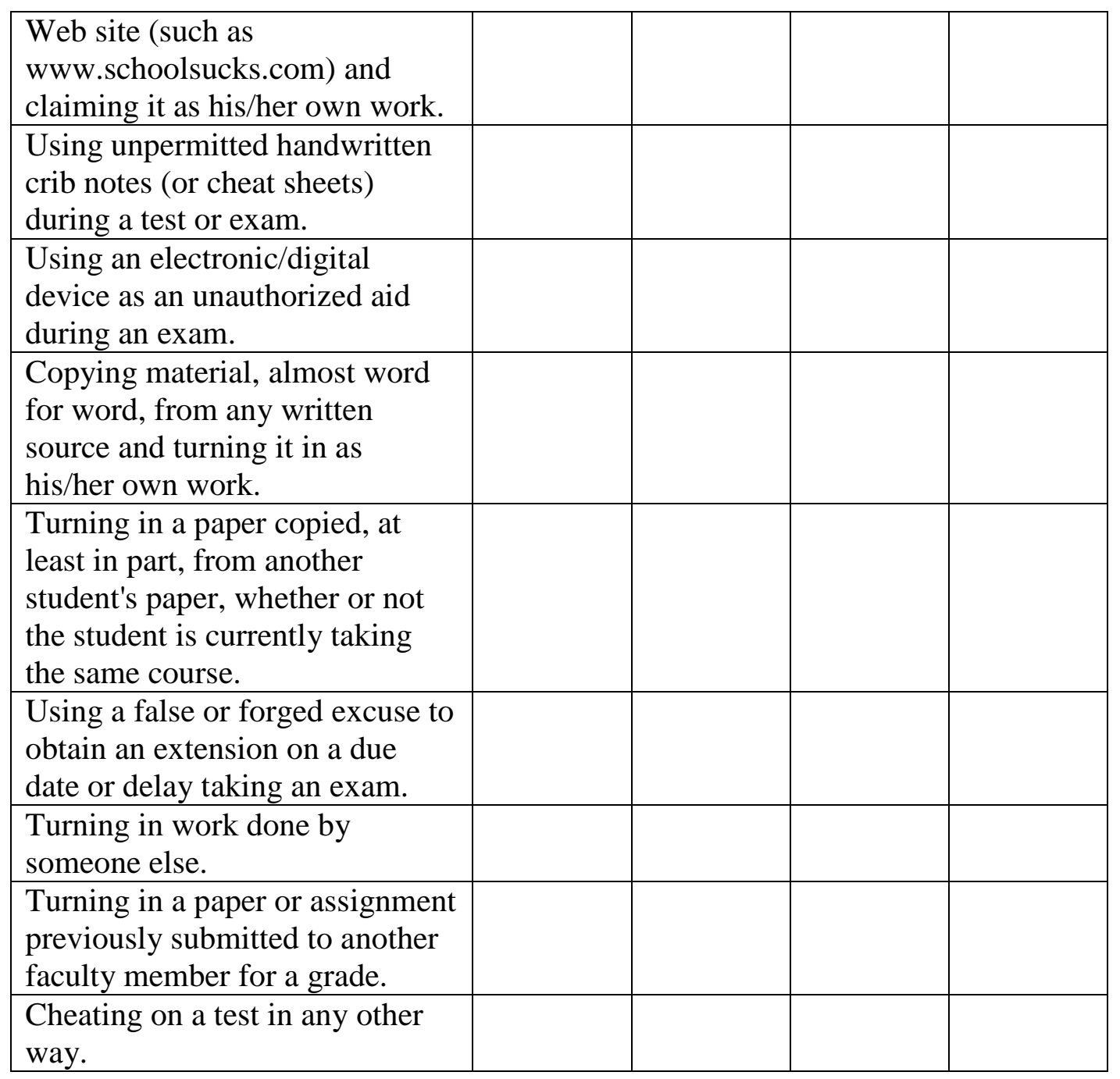

\section{Section III: Self-Plagiarism}

The next set of questions concern your perceptions of self-plagiarism. Please indicate your level of agreement (Strongly disagree, Disagree, Agree, Strongly agree) with the following statements by checking one response for each question.

Q16. How do you define self-plagiarism?

Q17. Self-plagiarism ...

\begin{tabular}{|l|l|l|l|l|}
\hline & $\begin{array}{c}\text { Strongly } \\
\text { Disagree }\end{array}$ & Disagree & Agree & $\begin{array}{c}\text { Strongly } \\
\text { Agree }\end{array}$ \\
\hline $\begin{array}{l}\text { (Q17a) ... is a clearly defined } \\
\text { concept. }\end{array}$ & & & & \\
\hline $\begin{array}{l}\text { (Q17b) ... is clearly understood by } \\
\text { faculty. }\end{array}$ & & & & \\
\hline
\end{tabular}


(Q17c) ... is clearly understood by students.

Q18. As a faculty member I should ...

\begin{tabular}{|l|l|l|l|l|}
\hline & $\begin{array}{l}\text { Strongly } \\
\text { Disagree }\end{array}$ & Disagree & Agree & $\begin{array}{c}\text { Strongly } \\
\text { Agree }\end{array}$ \\
\hline $\begin{array}{l}\text { (Q18a) ... teach students about } \\
\text { appropriate behaviors regarding self- } \\
\text { plagiarism. }\end{array}$ & & & & \\
\hline $\begin{array}{l}\text { (Q18b) ... assume students have been } \\
\text { educated about acceptable practices. }\end{array}$ & & & & \\
\hline $\begin{array}{l}\text { (Q18c) ... adhere to institutional policies } \\
\text { regarding self-plagiarism because I am a } \\
\text { role model. }\end{array}$ & & & & \\
\hline $\begin{array}{l}\text { (Q18d) ... report all student self- } \\
\text { plagiarism cases. }\end{array}$ & & & & \\
\hline $\begin{array}{l}\text { (Q18e) ... assume students do not } \\
\text { engage in self-plagiarism. }\end{array}$ & & & & \\
\hline $\begin{array}{l}\text { (Q18f) ... encourage students to reuse } \\
\text { parts of their previously submitted } \\
\text { papers for new assignments. }\end{array}$ & & & & \\
\hline
\end{tabular}

Q19. Students who ...

\begin{tabular}{|l|l|l|l|l|}
\hline & $\begin{array}{c}\text { Strongly } \\
\text { Disagree }\end{array}$ & Disagree & Agree & $\begin{array}{c}\text { Strongly } \\
\text { Agree }\end{array}$ \\
\hline $\begin{array}{l}\text { (Q19a) ... build on previous assignments } \\
\text { can increase their depth of learning. }\end{array}$ & & & & \\
\hline $\begin{array}{l}\text { (Q19b) ... incorporate previous } \\
\text { assignments in new assignments in } \\
\text { appropriate ways use their time wisely. }\end{array}$ & & & & \\
\hline $\begin{array}{l}\text { (Q19c) ... reuse part of previously } \\
\text { written papers for new assignments can } \\
\text { expect potential problems. }\end{array}$ & & & & \\
\hline
\end{tabular}

Q20. Students who ...

\begin{tabular}{|l|c|c|c|c|}
\hline & $\begin{array}{l}\text { Strongly } \\
\text { Disagree }\end{array}$ & Disagree & Agree & $\begin{array}{c}\text { Strongly } \\
\text { Agree }\end{array}$ \\
\hline $\begin{array}{l}\text { (Q20a) ... reuse a part of a previous } \\
\text { paper for a new assignment (if } \\
\text { appropriate to the new assignment) }\end{array}$ & & & & \\
\hline
\end{tabular}




\begin{tabular}{|l|l|l|l|l|}
\hline $\begin{array}{l}\text { without citing the previous paper are } \\
\text { self-plagiarizing. }\end{array}$ & & & & \\
\hline $\begin{array}{l}\text { (Q20b) ... reuse assignments that were } \\
\text { completed by a group of students in a } \\
\text { course are self-plagiarizing. }\end{array}$ & & & & \\
\hline $\begin{array}{l}\text { (Q20c) .. reuse a completed paper for a } \\
\text { new assignment are self-plagiarizing. }\end{array}$ & & & & \\
\hline $\begin{array}{l}\text { (Q20d) ... do NOT get my permission } \\
\text { when they recycle their work in my } \\
\text { courses are self-plagiarizing. }\end{array}$ & & & & \\
\hline
\end{tabular}

Q21.

(Q21). Students do NOT need to cite themselves if they use an excerpt they wrote for a previous paper to prevent selfplagiarism

\section{Section IV: Prevention Measures}

Q22. What safeguards do you employ to reduce cheating in your courses? (Check all that apply.)

None. I do not use any special safeguards in my courses.

Discuss my views on the importance of honesty and academic integrity with my students.

- Use the Internet, or software such as turnitin.com, to detect or confirm plagiarism.

_ Remind students periodically about their obligations under our University's academic integrity policy

Provide information about cheating/plagiarism on course outline, syllabus, or assignment sheet.

_ Closely monitor students taking a test/exam.

_ Change exams regularly.

Hand out different versions of an exam.

— Other

\section{Section V: Demographics}

Q23. How is your institution classified under the Carnegie Classification of Institutions of Higher Education?

_Doctoral/Research University

_Research University (High or Very High) 
Master's Colleges and Universities

__Baccalaureate Colleges

Q24. How many full-time instructional faculty are employed in your department?

$-0-9$

$-10-19$

_ 20 or more

Q25. What is your academic rank?

_ Assistant Professor

Associate Professor

Full Professor

_ Instructor/Lecturer

_ Lab Coordinator/Other

Q26. What academic level of students do you primarily teach?

_ lower level undergraduates (freshmen and sophomores)

_ upper level undergraduates (juniors and seniors)

_ graduate students

Q27. On average, how many students are enrolled in your largest course?

$-0-24$

25-49

50-74

- 75-99

— 100 or more

Q28. In which of the following areas is your primary area of teaching responsibility?

- Arts

_ Business

_ Communications/Journalism

_ Engineering

_ Humanities

_ Math or Science

_ Nursing/Health Professions

_ Social Sciences

_ Interdisciplinary

_ Other 
Q29. In which setting do you primarily teach?

_ On campus/face-to-face

Hybrid/blended (combination of class meetings and distance delivery)

_ Online (where at least $80 \%$ of course content is delivered online)

Q30. What is your race or ethnicity?

White, non-Hispanic

_ Black, non-Hispanic

_ Hispanic

Asian/Pacific Islander

_ Other

Q31. How long have you been teaching in higher education?

- 1-5 years

6-10 years

11-15 years

16-20 years

_ More than 20 years

Q32. What is your gender?

_ Male

_ Female

Thank you for participating in this survey! 


\section{Appendix C - Permission to Use and Adapt Survey Instrument}

Carleen Vincent

Tue 05/13/2014 3:45 PM

Sent Items

To: dmccabe@business.rutgers.edu;

Good evening Dr. McCabe.

My name is Carleen Vincent-Robinson, and I am a doctoral student in Higher Education at Florida International University. My research interests consist of academic integrity and misconduct among college students--more specifically, faculty perceptions of integrity. In preparing for my comprehensive exams, I have read several of your articles. I am writing to request access to the Faculty Academic Integrity Survey as well as your permission to use parts of the survey, if appropriate, for my dissertation. I look forward to your response.

Best regards,

Carleen Vincent-Robinson

McCabe, Donald <dmccabe@business.rutgers.edu>

Wed 05/14/2014 11:14 AM

Inbox

You have my permission and you may access a copy at https://honesty.rutgers.edu/rutgersfac,asp.

Tue 05/13/2014 3:42 PM

Sent Items 
To: colleenhalupa@letu.edu;

Action Items

Good afternoon Professor Halupa.

My name is Carleen Vincent-Robinson, and I am a doctoral student in Higher Education at Florida International University. My research interests consist of academic integrity and misconduct--specifically faculty perceptions of the same. I recently came across your 2013 article and would like to have access to your survey, if possible, as well as permission to use parts of it, if appropriate, for my dissertation.

Best regards,

Carleen Vincent-Robinson

Halupa, Colleen <ColleenHalupa@letu.edu >

Tue 05/13/2014 3:52 PM

To:

Carleen Vincent;

You replied on 05/13/2014 3:53 PM.

Certainly,

I have a student and faculty exploratory survey since I did research on both....would you like just the faculty one or would you like the student one as well? 


\section{Appendix D - Study Objectives and Survey Questions Content Matrix}

\begin{tabular}{|l|}
\hline Research Objectives \\
\hline How do university \\
faculty perceive \\
academic integrity \\
policies?
\end{tabular}

in

Research Questions

How do university faculty perceive academic integrity policies and student academic dishonesty (i.e., severity of penalties, faculty understanding of policies, faculty support of policies, effectiveness of policies)?

From what sources do university faculty obtain information about institutional policies?

Is there an established procedure for faculty to report student involvement in academic misconduct?

How do university faculty perceive institutional response and/or support to faculty reporting students' engagement in academic dishonesty?
Department chairs are supportive of and encourage faculty to report incidents of academic dishonesty.

\section{Survey Questions}

Question 1

Question 3

Question 9

Question 2

Question 2

Deans are supportive of and encourage faculty to report incidents of academic dishonesty.

Senior administrators are supportive of and encourage faculty to report incidents of academic dishonesty.

Have you ever referred a suspected case of cheating to your Chair, a Dean, or administrator?

How satisfied were you with the way the case(s) were handled?

Will you report future instances of academic misconduct to the appropriate

\section{Question 11}

Question 12

Question 13

\section{Question 2}

stion 12 


\begin{tabular}{|c|c|c|}
\hline & $\begin{array}{l}\text { Chair, dean, or other } \\
\text { administrator? }\end{array}$ & \\
\hline \multirow[t]{5}{*}{$\begin{array}{l}\text { How do university } \\
\text { faculty perceive student } \\
\text { engagement in } \\
\text { academic dishonesty? }\end{array}$} & $\begin{array}{l}\text { How frequently do you think } \\
\text { undergraduate students at your } \\
\text { institution engage in the } \\
\text { following behaviors? }\end{array}$ & Question 4 \\
\hline & $\begin{array}{l}\text { How frequently do you think } \\
\text { graduate students at your } \\
\text { institution engage in the } \\
\text { following behaviors? }\end{array}$ & Question 5 \\
\hline & $\begin{array}{l}\text { What experiences have } \\
\text { university faculty had with } \\
\text { academic dishonesty? }\end{array}$ & $\begin{array}{l}\text { Question } 11 \\
\text { Question } 12\end{array}$ \\
\hline & $\begin{array}{l}\text { What means do university } \\
\text { faculty employ to address } \\
\text { academic dishonesty? }\end{array}$ & $\begin{array}{l}\text { Question } 6 \\
\text { Question } 22\end{array}$ \\
\hline & $\begin{array}{l}\text { How do university faculty } \\
\text { understand self-plagiarism? }\end{array}$ & $\begin{array}{l}\text { Question } 16 \\
\text { Question } 17 \\
\text { Question } 18 \\
\text { Question } 19 \\
\text { Question } 20 \\
\text { Question 21 }\end{array}$ \\
\hline \multirow{4}{*}{$\begin{array}{l}\text { How are faculty } \\
\text { perceptions of } \\
\text { academic dishonesty } \\
\text { affected by } \\
\text { demographic } \\
\text { variations? }\end{array}$} & $\begin{array}{l}\text { Do the perceptions and } \\
\text { experiences of university } \\
\text { faculty vary by academic rank? }\end{array}$ & Question 25 \\
\hline & $\begin{array}{l}\text { Do the perceptions and } \\
\text { experiences of university } \\
\text { faculty vary in accordance with } \\
\text { the academic level of students } \\
\text { taught? }\end{array}$ & Question 26 \\
\hline & $\begin{array}{l}\text { Do the perceptions and } \\
\text { experiences of university } \\
\text { faculty vary across course } \\
\text { setting? }\end{array}$ & Question 29 \\
\hline & $\begin{array}{l}\text { Do the perceptions and } \\
\text { experiences of university } \\
\text { faculty vary by gender? }\end{array}$ & Question 32 \\
\hline
\end{tabular}




\section{Appendix E - Content Validity Letter to Experts}

Dear Sir or Madam:

My name is Carleen Vincent-Robinson, and I am a doctoral student at Florida

International University. For my dissertation, I am examining faculty perceptions of selfplagiarism and other forms of academic dishonesty among undergraduate students. The exact purpose of my study is to assess faculty perceptions of academic integrity including, but not limited to, identifying the types of behaviors construed as academic dishonesty, the severity of those behaviors, and determining what factors, if any, affect faculty responses to the same. The proposed instrument has been adapted from McCabe’s (2003) Faculty Academic Integrity Survey and Halupa and Bolliger's (2013) Faculty Perceptions of Self-Plagiarism Survey. Because you are an expert on academic dishonesty, I am soliciting your expertise and feedback on the attached survey. Your input will assist me in establishing the survey's content validity. These are the questions for which I am seeking your response:

1. Are the instructions clear and easy to understand?

2. Are the survey questions easy to understand?

3. Are there sufficient response categories for each of the questions?

4. Are the response categories appropriate for each of the questions?

5. Do the questions proceed in an appropriate order?

6. Do the questions assess faculty perceptions of academic dishonesty?

7. Do the questions appropriately include behaviors traditionally construed as academic dishonesty?

8. Are there behaviors that should not be included in the survey?

9. Are there behaviors that should be included in the survey but have not been included?

10. Do the questions allow for the assessment of the severity/seriousness of academically dishonest behaviors?

11. Do the questions allow for the identification of factors that may affect faculty perceptions of academic misconduct among students?

12. Any other questions or concerns.

Thank you for taking the time to assist me in my educational endeavors. If you have additional information or have questions, please contact me at the number listed below. 
VITA

\section{CARLEEN VINCENT-ROBINSON}

Born, New York, New York

1998

B.A., English Professional Writing

Baylor University

Waco, Texas

2001

J.D.

Louisiana State University

Baton Rouge, Louisiana

2001-2003

Judicial Clerk

Third Circuit Court of Appeals

Lake Charles, Louisiana

2002-2004

Graduate Research Assistant

Latin American and Caribbean Center

Florida International University

Miami, Florida

2004

M.S., Criminal Justice

Florida International University

Miami, Florida

2004-2007

Certified Teacher

Miami Dade County Public Schools

Miami, Florida

2007-2014

Full-Time Instructor

Department of Criminal Justice

Florida International University

Miami, Florida

2010

M.A., Sociology

University of Miami

Coral Gables, Florida

2014-2016

Doctoral Candidate

Florida International University

Miami, Florida 
2014 - Present

2015 - Present
Internship Director

Department of Criminal Justice

Florida International University

Miami, Florida

Senior Instructor

Department of Criminal Justice

Florida International University

Miami, Florida

\section{PUBLICATIONS AND PRESENTATIONS}

Collier, M., \& Vincent, C. (2005). Terrorism preparedness in Florida: Improved since 9/11, but far from ready. Miami, FL: Florida International University.

Robinson, C. V. (2013). Academic dishonesty: A guide for digital instructors. In M. S. Plakhotnik \& S. M. Nielsen (Eds.), Proceedings of the $12^{\text {th }}$ Annual South Florida Education Research Conference (pp. 189-194). Miami: Florida International University. Retrieved from http://education.fiu.edu/research_conference

Robinson, C.V. (2013, June). Financial aid: A promoter of equal access to higher education for incarcerated individuals. Paper presented at South Florida Education Research Conference. Miami, FL: Florida International University.

Robinson, C. V. (2013). From bars to textbooks: Bringing higher education behind bars. In M. S. Plakhotnik \& S. M. Nielsen (Eds.), Proceedings of the $12^{\text {th }}$ Annual South Florida Education Research Conference (pp. 195-200). Miami: Florida International University. Retrieved from http://education.fiu.edu/research_conference

Vincent, C. (2008, April). Democratizing the Third World Country that Nobody Wants: Bringing Haiti into the Forefront of Cultural Democratization. Paper presented at Southern Sociological Society. Richmond, Virginia.

Vincent, C., \& Chaudhuri, T. (2008, November). Black, White, rich or poor: Using demographic variables to explain domestic violence. Paper presented at American Society of Criminology. St. Louis, Missouri.

Vincent-Robinson, C. (2012, November). Apprehending the Cyber-Cheater in an Online Learning Environment: A Case Study. Paper presented at International Forum of Women in E-Learning. Bonita Springs, FL. 